\title{
ESTUDO DO SISTEMA REPRODUTIVO E DIVERGÊNCIA GENÉTICA EM CUPUAÇUZEIRO \\ (Theobroma grandiflorum (Willd ex Spreng) Schum.)
}

\section{RAINÉRIO MEIRELES DA SILVA}

Engenheiro Agrônomo

Orientador: Prof. Dr. PAULO SODERO MARTINS

\begin{abstract}
Dissertação apresentada à Escola Superior de Agricultura "Luiz de Queiroz", da Universidade de São Paulo, para obtenção do título de Mestre em Agronomia, Área de Concentração: Genética e Melhoramento de Plantas.
\end{abstract}

PIRACICABA

Estado de São Paulo - Brasil

Maio - 1996 
Dados Internacionais de Catalogação na Publicação (CIP)

DIVISÄO DE BIBLIOTECA E DOCUMENTAÇĀO - Campus "Luiz de Queiroz"/USP

\section{Silva, Rainério Meireles da}

Estudo do sistema reprodutivo e divergència genética em cupuaçuzeiro (Theobroma grandifforum (Willd ex Spreng) Schum.) / Rainério Meireles da Silva. - - Piracicaba, 1996.

151 p. : il.

Dissertação (mestrado) - Escola Superior de Agricultura Luiz de Queiroz, 1996.

Bibliografia.

1. Cupuaçu 2. Divergência genética 3. Morfologia 4. Polinizaçāo 5. Reprodução 1. Título

CDD 634.6 


\title{
ESTUDO DO SISTEMA REPRODUTIVO E DIVERGÊNCIA GENÉTICA EM CUPUAÇUZEIRO (Theobroma grandiflorum (Willd ex Spreng) Schum.)
}

\author{
RAINÉRIO MEIRELES DA SILVA
}

Aprovada em: 27.06.1996

Comissão julgadora:

Prof. Dr. Paulo Sodero Martins

ESALQ/USP

Prof. Dr. Gerhard Bandel

ESALQ/USP

Prof. Dr. Antonio Augusto Lucchesi

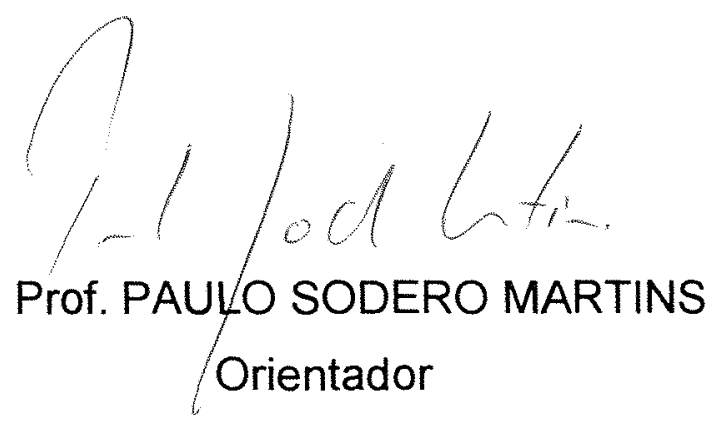


À Maria do Pilar Henriques das Neves

por tudo o que fez e, certamente, em seu regresso

ainda fará em prol do melhoramento genético das

plantas tropicais amazônicas.

\section{OFEREÇO}

Ao meu pai Raimundo André;

Aos meus queridos irmãos Ray-klem, Raulam e Rosinelma;

As minhas primas Angelita e Amanda;

Ao meu cunhado Sidney;

A minha linda sobrinha Bianca e, em especial, a Dona Naza (mãe) e Dona Sitônia (Vó), mulheres de grande sabedoria e que ao longo de suas vidas não mediram esforços para a minha formação.

\section{DEDICO}


A terra é de quem nela trabalha

É de quem quer ver seus frutos brotar.

E quando o lavrador tomba nela Justiça, justiça, clamará.

Quem roça, quem planta, quem trabalha

Da terra novos frutos sempre colherá.

Do sangue de quem morre pela terra, novamente A planta, na terra, brotará.

A morte dá esperança aos que lutam Aqueles que fazem da terra o plantar.

O Funeral do Lavrador - Teatro Experimental do Curió TEC, Belém-PA, 1989.

O dia em que todo trabalhador rural possuir o seu pedaço de terra e utilizar as tecnologias geradas pelo pesquisador, certamente, as condiçōes sociais, desse pais, serão mais justas e a pesquisa mais do que nunca valerá a pena. 


\section{Agradecimentos}

- Ao Departamento de Genética pela possibilidade de realização desse curso.

- Ao Prof. Dr. Paulo Sodero Martins pela orientação, ensinamentos transmitidos durante todo o curso e, principalmente, pela oportunidade de conviver com um ser humano, que, como poucos, consegue ser equilibrado em todos os campos da vida.

- À Coordenadoria de Aperfeiçoamento de Pessoal de Ensino Superior (CAPES) pela concessão da bolsa de estudo.

- Ao Centro de Pesquisa Agroflorestal da Amazônia Oriental CPATU/EMBRAPA, na pessoa do Dr. Dilson Frazão, pela possibilidade de condução do experimento de campo e coleta de dados.

- Ao pesquisador Rafael Alves pelo companheirismo e troca de informações durante a coleta dos dados.

- À Ph. D. Terezinha Bastos, da Estação Meteorológica do CPATU, pela concessão dos dados meteorológicos e proveitosa discussão a respeito do clima da Região Amazônica.

- Aos amigos Oriel Lemos, Ilmarina Menezes e os demais membros do laboratório de cultura de tecidos do CPATU pela amizade, incentivo e permissão de utilização dos equipamentos.

- Ao Dr. Olinto Neto, Ph. D. Cláudio Carvalho e Edson Artiaga, membros do laboratório de Ecofisiologia Vegetal do CPATU pelo incentivo, discussão e permissão para utilização dos equipamentos. 
- Ao pesquisador Urano Carvalho e demais membros do laboratório de sementes do CPATU pela discussão, incentivo e permissão para utilização de equipamentos.

- Aos Drs. Milton Mota, Irenice Vieira e aos pesquisadores Raimundo Parente, Carlos Martins e Hércules Lopes pela amizade e incentivo para a realização desse curso.

- Aos amigos Dênmora Araújo, Lucionila Pimentel, Marcos Farias, Paulo de Tarso, José Maria Pereira, Ray-klem Meireles e Andrey Pereira pelo colaboração na coleta dos dados de campo.

- À Rosinelma Meireles pelo trabalho de confecção dos protetores usados na polinização artificial.

- Ao amigo Lucivaldo Sena pela colaboração na composição das fotografias e Luiz Rodrigues pela confecção dos gráficos.

- Aos amigos do Movimento Jovem do Centro Comunitário "Jesus Maria José" pelo grande incentivo ao longo destes nove anos de valorosa amizade.

- À Maria Rita pelo incentivo no início dessa caminhada.

- Aos colegas do laboratório de Genética Ecológica, o meu muito obrigado pela oportunidade de convívio.

- À família Faraldo pela forma carinhosa que me recebeu.

- À Maria Inez Faraldo pelo companheirismo, boa convivência e principalmente por ser esta mulher extraordinária.

- Aos amigos Anacleto dos Santos, José Gama e Paulo César pela convivência e grande aprendizado durante a minha estada em Piracicaba.

- Ao amigo Carlos Tadeu, pela convivência e inestimável contribuição nas análises estatísticas. 
- Ao Prof. Paulo Curi, do Serviço de Estatistica da Faculdade de Medicina Veterinária e Zootecnia - FMVZ-UNESP e Cássio van den Berg pelas valiosas contribuições na análise estatística.

- Aos funcionários do Departamento de Genética, em especial a Ronaldo Rabello, Carmen Piloto, Léia de Oliveira, Silvana Gregório. e Elizabeth Santos, pela amizade e facilidades concedidas durante o curso.

- Aos amigos do Curso de Pós-graduação, em especial a Rogério Melo, Welington Araújo, André Lima, Carlos Aguilar e Angela Lopes pelo constante apoio, principalmente, nas horas mais dificeis dessa caminhada.

- Ao Prof. Ando pela amizade, e forma alegre, muito contagiante, de ser.

- À Wanda Lima pela boa convivência e amizade.

- Ao amigo Geraldo Aquino pela colaboração na correção dessa dissertação.

- A todos que contribuiram para a realização deste trabalho, o meu muito obrigado, certamente sem ajuda de vocês um trabalho com estas proporções não seria realizado. 


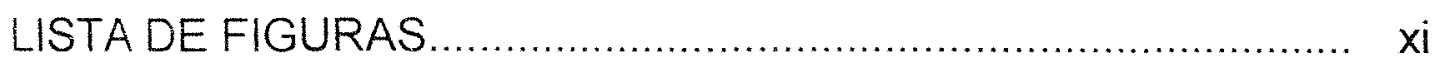

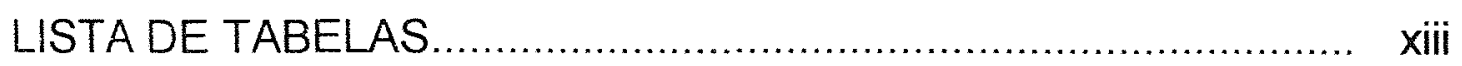

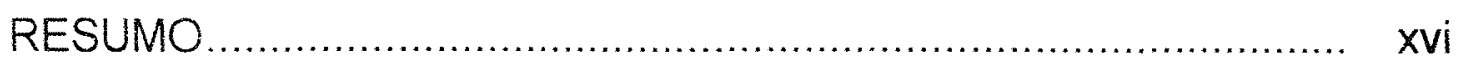

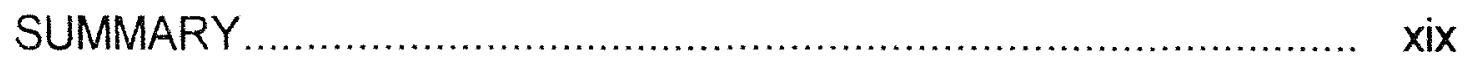

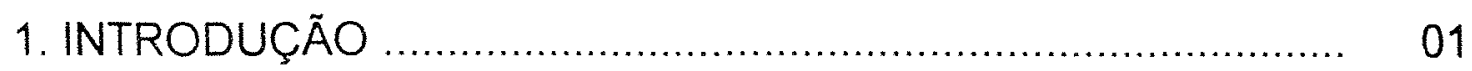

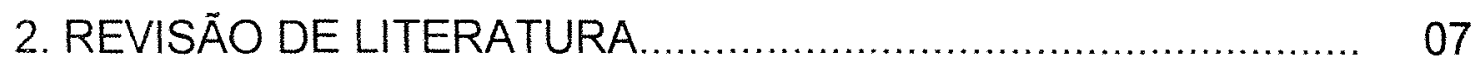

2.1. Taxonomia do cupuaçuzeiro ............................................... 07

2.2. Distribuição geográfica do cupuaçuzeiro ................................ 09

2.3. Condições climáticas e edáficas para o cupuaçuzeiro............... 09

2.4. Caracterização botânica do cupuaçuzeiro .............................. 10

2.5. Fenologia da floração e frutificação do cupuaçuzeiro................ 14

2.6. Biologia floral do cupuaçuzeiro ........................................... 16

2.6.1. Estádios da floração e frutificação …………...................... 16

2.6.2. Abertura da flor........................................................... 18

26.3. Receptibilidade do estigma e estilete da flor ....................... 18

2.6.4. Cor da flor ............................................................... 19

2.6.5. Exalação de odor.......................................................... 19

2.6.6. Estudos palinológicos................................................ 20

2.6.7. Polinização natural e insetos polinizadores.......................... 20

2.7. Sistema reprodutivo e sexualidade floral em plantas arbóreas tropicais.

2.8 Hipóteses que se propõem a explicar a proporção flor:fruto............................................................................ 25

2.9 Influência ambiental sobre o sistema reprodutivo..................... 27

2.10. Análise do sistema reprodutivo através de marcadores isenzimáticos................................................................ 29

2.11. Sistema de auto-incompatibilidade (SAl) ............................ 30

2.11.1. Tipos de sistema de auto-incompatibilidade (SAI).............. 33

2.11.2. Modificação e perda do sistema de auto-incompatibilidade.. 35

2.11.3. Incompatibilidade genética na familia Sterculiaceae........... 38

2.12. Isolamento da flor do cupuaçuzeiro....................................... 41

2.13. Polinização artificial do cupuaçuzeiro ..................................... 41

2.14. Sistema reprodutivo do cupuaçuzeiro ................................... 43 
2.15. Utilização da análise multivariada na avaliação da divergência genética................................................... 43

2.15.1. Análise de agrupamento aglomerativo.......................... 44

2.15.2. Análise por variáveis canônicas................................... 47

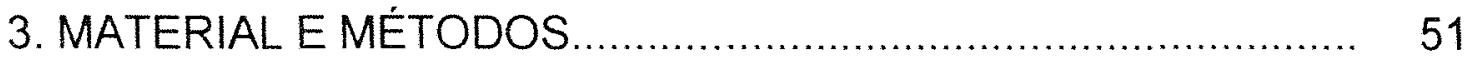

3.1. Material..................................................................... 51

3.1.1. Descrição da área de estudo e caracterização climática................................................................... 51

3.1.2. Aspectos do material usado na coleta dos dados .............. 52

3.2. Métodos.............................................................. 55

3.2.1. Fenologia da floração e frutificação ................................. 55

3.2.2. Caracterização floral.................................................. 56

3.2.3. Determinação direta do sistema reprodutivo ..................... 58

3.2.4. Determinação indireta do sistema reprodutivo .................. 62

3.2.4.1. Relação entre morfologia, viabilidade floral e o sistema reprodutivo ......................................................... 62

3.2.4.2. Proporção pólen:óvulo (P:O) ............................... 63

3.2.5. Determinação da divergência genética pela utilização de análise multivariada..................................................... 64

3.2.5.1. Análise de agrupamento........................................... 65

3.2.5.1.1. Método de agrupamento utilizando o algoritmo de ligação média não ponderada (UPGMA).

3.2.5.1.2. Método de agrupamento pelo método de otimização de Tocher.............................................................. 66

3.2.5.2. Material utilizado na análise de divergência genética......... 67

3.2.6. Operacionalização das análises...................................... 68

4. RESULTADOS E DISCUSSÃO ....................................... 70

4.1. Fenologia da floração e frutificação.................................. 70

4.2. Hipóteses que se propõem a explicar a proporção flor:fruto..... 81

4.3. Variação no início da floração dentro dos clones.................... 86

4.4. Caracterização floral...................................................... 87

4.4.1. Cor da flor ............................................................. 87

4.4.2. Estimativa da quantidade de grãos de pólen na flor............. 89

4.4.3. Viabilidade dos grãos de pólen ................................... 91

4.4.4. Contagem de óvulos .................................................. 91

4.5. A relação entre tamanho de flor e percentual de frutos

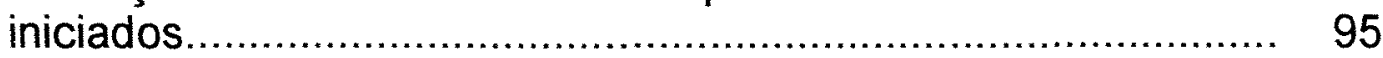

4.6. Determinação direta do sistema reprodutivo....................... 98

4.6.1. Polinização aberta....................................................... 100

4.6.2. Agamospermia................................................. 102 
4.6.3 Autopolinização espontânea........................................ 102

4.6.4. Autopolinização forçada (gueitonogamia) ....................... 102

4.6.5. Polinização cruzada (xenogamia)................................... 103

4.7. Determinação indireta do sistema reprodutivo.................... 110

4.7.1. Relação entre morfologia, viabilidade e sistema reprodutivo.. 110

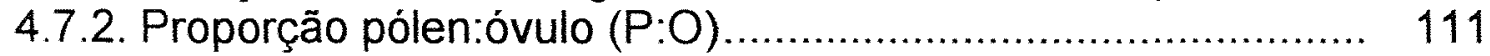

4.8. Relações genéticas entre os clones baseados em caracteres de morfologia floral e de fruto............................................. 113

4.8.1. Análise univariada................................................... 113

4.8.2. Estimativa da divergência genética obtida pela distância generalizada de Mahalanobis

4.8.2.1. Análise de agrupamento pelo método de otimização de Tocher.

4.8.2.2. Análise de agrupamento utilizando o algoritmo de ligação média não ponderada

4.8.2.3. Análise por variáveis canônicas

4.9. Relação entre a divergência genética e compatibilidade entre os clones.

5. CONCLUSÕES 


\section{LISTA DE FIGURAS}

Figura 1: Mapa de localização geográfica das regiões de origem dos seis clones e local de coleta dos dados do presente trabalho.

Figura 2: Botão floral do cupuaçuzeiro. A: estádio $4-B F \geqslant 12$ $\mathrm{mm}$ (botão fechado igual ou maior que 12 milimetros de diâmetro) e B: estádio 8 - BF3A (botão fechado com três aberturas no cálice).

Figura 3: Flor do cupuaçuzeiro em vista lateral e as diversas partes que a compõem. S: sépala; L: lâmina da pétala; $C$ : cúcula; e $P$ : pedúnculo

Figura 4. Relação entre a quantidade de flores emitidas e a precipitação pluviométrica, em seis clones de cupuaçuzeiro (Theobroma grandiflorum) em Belém-PA, no ano de 1994.

Figura 5. Relação entre a quantidade de flores emitidas e a precipitação pluviométrica, em seis clones de cupuaçuzeiro (Theobroma grandiflorum) em

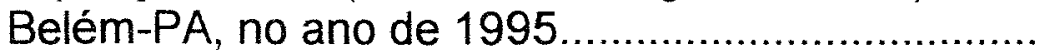

Figura 6. Relação entre a floração e a precipitação pluviométrica, médias de seis clones de cupuaçuzeiro (Theobroma grandiflorum) em

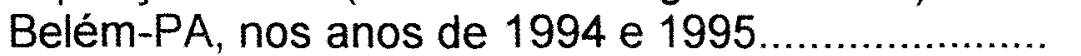

Figura 7: Potencial reprodutivo: percentual médio de gemas florais que foram derrubadas nas fases de botão floral, flor, fruto imaturo e fruto maduro, em seis clones de cupuaçuzeiro (Theobroma grandiflorum), em Belém-PA, nos anos de 1994 e 1995.

Figura 8: Flor aberta do cupuaçuzeiro. A - clone Muaná1, $3,69 \mathrm{~cm}$; $\mathrm{B}$ - clone Anamã $3,50 \mathrm{~cm}$; C - clone Tefé $3,46 \mathrm{~cm}$; D - clone Coarí $3,52 \mathrm{~cm}$; e $E$ - clone Muaná2 $3,71 \mathrm{~cm}$. 
Figura 9: Ovário de cupuaçuzeiro após a remoção da parede. $A$ : ovário do clone Anamã e $B$ : ovário do clone Coarí. As setas indicam a quantidade de óvulos em um lóculo do ovário

94

Figura 10: Fruto imaturo resultante do cruzamento Muaná1 x Coari aos 30 dias após à polinização protegido pelo PRAMP

Figura 11: Dendrograma ilustrativo do padrão de similaridade estabelecido pelo Método Hierárquico Aglomerativo de ligação média não ponderada (UPGMA), fundamentado na distância generalizada de Mahalanobis, utilizando 19 caracteres de flor e fruto, em cinco clones de cupuaçuzeiro (Theobroma grandiflorum)

Figura 12: Ordenação bidimensional dos clones de cupuaçuzeiro (Theobroma grandiflorum), utilizando-se as duas primeiras variáveis canônicas (CAN 1 e CAN2), disposição das 19 variáveis avaliadas e indicação dos agrupamentos formados.

Figura 13: Flor e fruto do cupuaçuzeiro: $\mathrm{A}$ e $\mathrm{C}$ : flor e fruto do clone Muaná1. B e D: flor e fruto do clone Coarí... 


\section{LISTA DE TABELAS}

Tabela 1: Potencial de florescimento. Os valores são percentuais baseados em três repetições por clone, que foram derrubados na fase de botão, flor, fruto imaturo, fruto maduro e total de gemas florais emitidas em seis clones de cupuaçuzeiro (Theobroma grandiflorum) em Belém - PA, no ano de 1994.

Tabela 2: Potencial de florescimento. Os valores são percentuais baseados em três repetições por clone, que foram derrubados na fase de botão, flor, fruto imaturo, fruto maduro e total de gemas florais emitidas em seis clones de cupuaçuzeiro (Theobroma grandiflorum) em Belém - PA, no ano de 1995.

Tabela 3: Aptidão para macho função: Os valores são médias de número de grãos de pólen e desvios-padrões baseados, em seis repetições, de cinco clones de cupuaçuzeiro (Theobroma grandiflorum).

Tabela 4: Aptidão para função feminina: Os valores são médias de óvulos por lóculo, ovário, desvios-padrões e amplitude baseados em seis repetições em cinco clones de cupuaçuzeiro (Theobroma grandiflorum)

Tabela 5: Potencial de conversão de óvulos em sementes. 0 número de óvulos por ovário foi baseado em amostra de seis ovários, todavia o número de sementes foi obtido a partir de número variado de frutos, em cinco clones de cupuaçuzeiro (Theobroma grandiflorum)

Tabela 6: Análise da variância do tamanho de flor em cinco clones de cupuaçuzeiro (Theobroma grandiflorum) 
Tabela 7: Teste de Tukey para as médias de tamanho de flor em cinco clones de cupuaçuzeiro (Theobroma grandiflorum).....

Tabela 8: Determinação direta do sistema reprodutivo em função do sistema de polinização. Os valores foram obtidos de três repetições em cinco clones de cupuaçuzeiro (Theobroma grandiflorum) em BelémPA, nos anos de 1994 e 1995.

Tabela 9: Determinação direta do sistema reprodutivo: tratamentos de autopolinização e polinização cruzada. Número de polinizações realizadas, avaliação da fertilização aos doze dias, percentual de fertilização e frutificação após seis meses de realizada a polinização artificial em cinco clones de cupuaçuzeiro (Theobroma grandiflorum), em Belém-PA, no ano de 1994.

Tabela 10: Determinação direta do sistema reprodutivo ao longo do período da floração: tratamentos de autopolinização e polinização cruzada. Número de polinizações realizadas, avaliação da fertilização aos doze dias, percentual de fertilização em cinco clones de cupuaçuzeiro (Theobroma grandiflorum) em Belém-PA no ano de 1995

Tabela 11: Determinação indireta do sistema reprodutivo: proporção pólen:óvulo. Os valores são médias baseadas em seis repetições por clone para a produção de grãos de pólen e óvulos por ovário em cinco clones de cupuaçuzeiro (Theobroma grandiflorum)

Tabela 12: Resumo da análise da variância de 19 caracteres avaliados em cinco clones de cupuaçuzeiro em delineamento inteiramente casualizado.

Tabela 13 - Medidas de dissimilaridade genética entre pares de clones de cupuaçuzeiro (Theobroma grandiflorum), fundamentadas na distância generalizada de 
Mahalanobis $\left(\mathrm{D}^{2} \mathrm{ii}\right)$ a partir de 19 caracteres de morfologia floral e fruto.

Tabela 14 - Grupos com padrões de comportamento similares estabelecidos pelo método de otimização de Tocher, e distância média dentro de grupo, provenientes da avaliação de 19 caracteres da morfologia floral e fruto em cinco clones de cupuaçuzeiro (Theobroma grandiflorum)

Tabela 15 - Distâncias médias entre os grupos formados pelo método de otimização de Tocher, provenientes da avaliação de 19 caracteres da morfologia floral e fruto em cinco clones de cupuaçuzeiro (Theobroma grandiflorum)

Tabela 16: Correlação entre as variáveis originais e a estrutura canônica (CAN1, CAN2, CAN3 e CAN4). Origem das variáveis originais, porcentagem de informação retida pelas variáveis canônicas (\% variável) e ordenação das variáveis originais, conforme seu poder discriminatório obtido pela ponderação das quatro variáveis canônicas em relação ao percentual de informação contida pela variável. 
ESTUDO DO SISTEMA REPRODUTIVO E DIVERGÊNCIA GENÉTICA EM CUPUAÇUZEIRO (Theobroma grandiflorum (Willd ex Spreng) Schum.)

\author{
Autor: Rainério Meireles da Silva \\ Orientador: Prof. Dr. Paulo Sodero Martins
}

\title{
RESUMO
}

O cupuaçuzeiro (Theobroma grandiflorum (Willd ex Spreng) Schum.), é uma espécie pertencente à familia Sterculiaceae, nativa da Região Amazônica, que ao longo do tempo vem sendo explorada pelos índios e caboclos regionais e, atualmente, desperta grande interesse nos mercados regional e nacional apresentando grandes perspectivas para o futuro, com o início das exportações. $O$ principal produto da planta é a polpa do fruto, a qual é consumida na forma de suco, doce, compota, geléia, sorvete, etc. Embora apresentando muitas qualidades, a espécie tem sua produção baseada no semi-extrativismo e em pequenos plantios comerciais que vêm sendo implantados de maneira desordenada, com material de baixo valor genético, apresentando baixa produtividade, necessitando assim, de estudos básicos, a exemplo do sistema reprodutivo e divergência genética, para que seja transformada em cultura economicamente expressiva.

Dentro deste contexto, os objetivos do presente estudo foram: analisar o comportamento do sistema reprodutivo do cupuaçuzeiro ao longo do período de florescimento, caracterizar a estrutura floral, 
determinar o sistema reprodutivo através da morfologia e comportamento da flor e determinar a divergência genética entre os clones utilizando caracteres morfológicos da flor e do fruto. Para tanto, foram utilizados dados de fenologia floral e frutificação, biologia floral, polinização controlada e dados morfométricos da morfologia floral e do fruto de 19 caracteres, para avaliar a divergência genética através dos processos multivariados de agrupamento fundamentado na distância generalizada de Mahalanobis e utilizando o algoritmo de ligação média não ponderada (UPGMA), método de otimização de Tocher e variáveis canônicas. A análise foi desenvolvida através da Procedure CANDISC do Systems of Analysis Statistics (SAS).

Considerando as condições em que foi realizado este trabalho, os resultados permitiram obter as seguintes conclusões:

- O cupuaçuzeiro apresenta o modelo de floração em picos, com um principal e dois ou três menores, sendo que a floração ocorre no período seco apresentando grande oscilação entre os dois anos estudados.

- A espécie mostra variação na coloração da flor, número de óvulos no ovário e número de grãos de pólens produzidos.

- Em cupuaçuzeiro, polinização satisfatória não significa que o fruto irá atingir a maturação, porém todo fruto maduro foi originado a partir de uma polinização satisfatória.

- A espécie apresenta alta conversão de óvulos em sementes.

- Os clones apresentam alto grau de auto-incompatibilidade, não aceitando autofertilização. Portanto a alogamia é a forma predominante de reprodução, sendo que este sistema reprodutivo não muda durante o período da floração. 
- O método de determinação indireta do sistema reprodutivo baseado na morfologia e comportamento floral é mais eficiente que a proporção pólen:óvulo.

- Os métodos utilizados para determinar a divergência genética mostram a formação de três grupos, o primeiro formado com os clones originados do Pará e os outros dois formados com os clones originados do Amazonas.

- Os clones mais próximos geneticamente (Muaná1 e Muaná2) evitam as trocas gênicas através do mecanismo de incompatibilidade.

- Os caracteres da morfologia floral e fruto apresentam poder discriminatório que possibilitam sua utilização na avaliação da divergência genética do cupuaçuzeiro. 
STUDY OF THE REPRODUCTIVE SYSTEM AND GENETIC DIVERGENCE IN CUPUASSU (Theobroma grandiflorum (Willd ex Spreng) Schum.).

\author{
Author: Rainério Meireles da Silva \\ Adviser: Prof. Dr. Paulo Sodero Martins
}

\title{
SUMMARY
}

The cupuassu (Theobroma grandiflorum (Willd ex Spreng) Schum.) is a species of the Sterculiaceae family, native of the Amazonian region, which has been explored by the indians and "caboclos" and is now having great interest in local and national markets, showing large perspectives for the future with the beginning of exportations. In spite of showing many qualities, its production is based on semiextrativism and small commercial crops with material of low genetic potential and low productivity. It will be necessary to develop basic studies, as the reproductive system and genetic divergence, to transform the species in a crop with expressive economic value.

Within this scope, the objectives of this study were: to analyse the behavior of the reproductive system of cupuassu during the flowering period, to characterize the floral structure, to determine the reproductive system using the flower morphology and behavior and to stablish the genetic divergence among clones using the flower and fruit morphological characters.

Data on floral and fruit phenology, floral biology, controlled pollinations and morphometry of 19 floral and fruit characters 
were used to evaluate the genetic divergence among classes through multivariate cluster analysis based on Mahalanobis' generalized distance and using the UPGMA, the Tocher's optimization method and canonical variables. The analysis were performed through the CANDISC Procedure of SAS.

Considering the conditions in which this study was conducted, the following conclusions were obtained:

- the cupuassu shows a flowering pattern with a main peak and two or three secondary ones, occurring during the dry period and showing large variation between the two years of study.

- the species shows variation in flower color, number of ovules in the ovary and number of pollen grains.

- in cupuassu, satisfactory pollination does not mean that the fruit will maturate, although all mature fruit originates from a satisfactory pollination.

- the species shows a high conversion of ovules in seeds.

- the clones show high degree of self-incompatibility. Therefore alogamy is the main strategy of reproduction.

- the indirect method of determination of the reproductive system based on morphology and floral behavior is more efficient than the pollen:ovule rate.

- the methods utilized to determine genetic divergence differentiated three groups, the first group with the clones from Para and the other two formed with the clones from Amazon.

- the nearest clones (Muaná1 and Muaná2) are genetically incompatible. 
- the floral and fruit morphological characters show discriminatory power which permit their utilization in the analysis of divergence in cupuassu. 


\section{INTRODUÇÃO}

O termo sistema reprodutivo num sentido restrito, refere-se à forma como os indivíduos se reproduzem, todavia em sentido mais amplo, corresponde a todos os aspectos da reprodução em plantas, que afetam a contribuição genética para a próxima geração, dentro de uma espécie.

O sistema reprodutivo determina 0 modelo de transmissão genética e afeta a organização da variabilidade genética da população. A endogamia restringe a heterozigosidade e migração realizada pelo fluxo gênico, reduz a variação dentro da população e aumenta a variabilidade entre as populações. Em contraste, a exogamia promove o fluxo gênico, diminui a variabilidade entre as populações, reduz a probabilidade de diferenciação microgeográfica e subestruturação da população.

Segundo Brown (1990) as plantas transmitem suas características genéticas aos descendentes de cinco formas: 1) predominantemente por autofertilização (autogamia); 2) predominantemente por fertilização cruzada (alogamia); 3) por combinação de autogamia e alogamia (mista); 4) por apomixia parcial e 5) por autofertilização parcial dos gametófitos ( como ocorre em samambaia e na reprodução de dihaplóides). Contudo, Jain (1984) observa que as cinco formas do sistema reprodutivo compõem um contínuo. 
O conhecimento do sistema reprodutivo utilizado pela espécie é de fundamental importância para o desenvolvimento dos programas de melhoramento genético, pois permite escolher o método de melhoramento mais adequado a ser empregado.

Brown et al. (1985), enfatizam a importância de se conhecer o modo de reprodução das plantas para auxiliar no manejo das culturas, florestas e pomares, e potencial aplicação no manejo de espécies silvestres para conservação de sua variabilidade genética.

Outra utilização prática de grande interesse é a manutenção de material melhorado, no caso de hibrido originado de uma espécie alógama. Para manter sua pureza genética, é necessário que as linhagens endogâmicas que deram origem ao hibrido, sejam preservadas. Porém, se é um cultivar, originado de uma espécie autógama, somente será necessário realizar o replantio para a manutenção do material.

Os diferentes sistemas reprodutivos estão, normalmente, associados aos estágios sucessionais da vegetação. Conforme Baker (1955), as plantas colonizadoras de áreas perturbadas, comumente encontradas próximas às áreas habitadas, na borda das florestas, à beira de rodovias, etc. e plantas de estágio sucessional inicial, tendem a ser autocompativeis e/ou autógamas, enquanto que plantas de estágio sucessional mais tardio, incluindo árvores de florestas tropicais, tendem a ser de fertilização cruzada.

Em populações exogâmicas, autofertilização combinada com cruzamentos entre vizinhos próximos com a mesma estrutura genotípica e limitada dispersão de sementes pode levar ao isolamento reprodutivo e formação de subpopulações (Levin \& Kerster, 1974), iniciando, dessa forma, um processo de especiação simpátrica. 
Para Holsinger (1991) os danos causados pela depressão endogâmica têm sido uma das principais razões para se estudar o sistema reprodutivo das plantas.

São poucas as informaçōes a respeito do sistema reprodutivo de árvores de florestas tropicais, porém, desde que Bawa (1974) mostrou que havia predominância de alogamia, apesar de possuírem, geralmente, flores hermafroditas (Aubréville, 1938; Bullock, 1985), o assunto passou a receber a atenção de muitos pesquisadores.

Tratando-se de espécies arbóreas da floresta tropical amazônica, as informações são, ainda, mais raras. Jardim (1991), estudando os aspectos da biologia reprodutiva do açaizeiro (Euterpe oleracea), palmeira típica da região, constatou predominância de alogamia, com pequena produção de frutos por autogamia.

O cupuaçuzeiro (Theobroma grandiflorum (Willd ex Spreng) Schum.), é uma espécie pertencente à família Sterculiaceae, nativa da Região Amazônica, que ao longo do tempo vem sendo explorada pelos indios e caboclos regionais $\mathrm{e}$, atualmente, desperta grande interesse no mercado regional, nacional apresentando grandes perspectivas para o futuro, com o inicio das exportações.

O cupuaçu, denominação mais comum da fruta do cupuaçuzeiro, é tradicionalmente consumido principalmente, na forma de vinho (suco) pelo caboclo regional, o qual retira a polpa, mucilagem que envolve as sementes, com o auxílio de tesoura, processo artesanal que vem sendo mantido até os dias atuais, embora existam máquinas despolpadeiras.

Atualmente, o maior valor da planta está no aproveitamento dos produtos obtidos da polpa, na forma de sucos, sorvetes, cremes, doces, (Costa et al., 1960; Cavalcante, 1974), néctar 
(Barbosa et al., 1978), licores, compotas, bombons, geléias, etc. (Calzavara et al., 1984), o que representa, aproximadamente, 35\% da fruta. A planta fornece madeira parda, amarelo-claro, bastante homogênea, mas pouco utilizada e o fruto não apresenta cafeina e alcalóides (Prance \& Silva, 1975).

As sementes, que representam cerca de $20 \%$ do peso total da fruta, possuem segundo Ribeiro et al. (1993) $61 \%$ do seu peso seco constituido de fina gordura, de fácil digestibilidade e apresentam possibilidade de obtenção de chocolate branco, considerado de boa qualidade (Calzavara, 1972). Segundo Nazaré et al. (1990), após o processamento das sementes, obtém-se o cupulate (termo empregado ao chocolate produzido a partir das amêndoas do cupuaçuzeiro) em tabletes branco, meio amargo e com leite, produto com características nutritivas e organolépticas semelhantes às do chocolate obtido das amêndoas do cacaueiro, que é uma espécie do mesmo gênero (Theobroma).

A produção de cupulate, o qual é comercializado com o nome comercial de "Chocam", é distribuída em Manaus, Belém, Fortaleza, São Luiz, Brasilia e exportado para os Estados Unidos, e encontra-se em grande expansão, pois em apenas um ano quintuplicou, e tende a crescer, pois o montante produzido somente atinge $10 \%$ do comércio de achocolatados comercializados no Estado do Amazonas (Lozano, 1994).

A ausência de estudos das espécies amazônicas, na região, tem causado a saída desses materiais para outros centros, que depois de melhorados, contribuem para o seu desenvolvimento, a exemplo do cacaueiro (Theobroma cacao) para a Bahia e a seringueira (Hevea brasiliensis) para a Malásia. 
Com a finalidade de desenvolver culturas, para as condições da Amazônia, nas últimas décadas, materiais com características agronomicamente desejáveis vêm sendo coletados e implantados nos Bancos de Germoplasma, instalados nos campos experimentais dos órgãos de pesquisa. Entre as espécies coletadas, o cupuaçuzeiro encontra-se entre as mais promissoras, pois além de grande importância quanto ao aspecto comercial, apresenta caracteristicas para ser utilizada em sistemas agroflorestais e consiste em um bom exemplo para estudos da ecologia regional.

O cupuaçuzeiro, embora apresentando muitas qualidades, tem sua produção baseada no semi-extrativismo e em pequenos plantios comerciais que vêm sendo implantados de maneira desordenada, com material de baixo valor genético, apresentando baixa produtividade, necessitando assim, de estudos básicos, a exemplo do sistema reprodutivo, para que seja transformada em cultura economicamente expressiva.

Dentro deste contexto, os objetivos do presente estudo foram:

- Analisar o comportamento do sistema reprodutivo do cupuaçuzeiro. (Theobroma grandiflorum) ao longo do período de florescimento;

- Caracterizar a estrutura floral dos clones estudados; 
- Determinar o sistema reprodutivo através de polinizaçãos controladas e através da morfologia e comportamento da flor;

- Determinar a divergência genética entre os clones utilizando caracteres morfológicos da flor e do fruto. 


\section{REVISÃO DE LITERATURA}

\subsection{Taxonomia do cupuaçuzeiro}

Segundo a classificação botânica internacional, o cupuaçuzeiro pertence a divisão Anthophyta, subdivisão Angiospermae, classe das dicotiledôneas, subclasse Dilleniidae (= Choripetalae), superordem Malvanae, ordem Malvales (= Columniferae), sub-ordem Malvinea, família Sterculiaceae, gênero Theobroma e espécie Theobroma grandiflorum (Willdenow ex Sprengel) Schumann) (Wettstein, 1944; Maas \& Westra, 1993).

Conforme a classificação de Cuatrecasas (1964) o gênero Theobroma apresenta 22 espécies todas originadas na América Tropical. A espécie $T$. cacao é a mais cultivada e $T$. grandiflorum a que apresenta fruto de maior de tamanho. $O$ autor dividiu o gênero em seis seções: Andropetalum, Glossopetalum, Oreanthes, Ritidocarpos, Telmatocarpus e Theobroma. Todas são encontradas na Amazônia, exceto a seção Andropetalum, a qual é formada pela espécie $T$. mammosum encontrada na Costa Rica.

As relações filogenéticas entre as nove espécies do gênero Theobroma existentes na Amazônia brasileira foram estudadas através de cruzamentos interespecíficos e enxertia por Addison \& Tavares (1951), que obtiveram um hibrido fértil entre as espécies $T$. grandiflorum e $T$. obovatum e encontraram estreita relação entre as 
grandiflorum e $T$. obovatum e encontraram estreita relação entre as espécies $T$. grandiflorum, $T$. obovatum e $T$. subincanum e entre $T$. spruceanum e $T$. speciosum. A espécie $T$. bicolor foi a que apresentou a menor relação filogenética entre as espécies estudadas.

Os autores anteriores não obtiveram resultado satisfatório no cruzamento entre $T$. grandiflorum e $T$. cacao, o que foi obtido por Martinson (1972) trabalhando em Gana, indicando, dessa forma, possivel estreita relação filogenética entre estas duas espécies.

A espécie $T$. grandiflorum apresenta $2 n=20$ cromossomos (Carletto, 1946), sendo que Clement e colaboradores, identificaram uma variedade triplóide, por contagem de 30 cromossomos em célula somática (Hans Müller) ${ }^{1}$.

A denominação cupuaçu, tem como origem o tupi, sendo comum e difundida no interior dos Estados da Região Amazônica a abreviação "cupu". Este termo também, é aplicado ao fruto da espécie Theobroma bicolor H. B. K., o qual é vulgarmente conhecido por cacaudo-peru, sendo que as duas espécies podem ser diferenciadas pelas características das folhas e formato do fruto (Calzavara et al., 1984).

Os mesmos autores, utilizaram o formato do fruto, para classificar as variedades botânicas de cupuaçuzeiro, em:

1 - Cupuaçu redondo: possui os frutos com a extremidade arredondada, sendo o mais comum na região;

2 - Cupuaçu mamorana: os frutos apresentam-se com a extremidade comprida, semelhante a um bico ou ponta. $\dot{E}$ a variedade que produz os frutos de maior tamanho e peso;

3 - Cupuaçu mamau: variedade triplóide com alto grau de esterilidade e, consequentemente, com frutos que não apresentam sementes.

\footnotetext{
${ }^{1}$ HANS MÜLLER, C. (EMBRAPA - Centro Agroflorestal da Amazônia Oriental CPATU) Comunicação pessoal, 1995.
} 


\subsection{Distribuição geográfica do cupuaçuzeiro}

O cupuaçuzeiro é encontrado espontaneamente nas matas de terra firme e várzea alta, na parte Sul e Leste do Pará, abrangendo as áreas do Médio Tapajós, rios Xingu e Guamá, alcançando - Nordeste do Maranhão, principalmente nos rios Turiaçu e Pindaré. Também foi encontrado, provavelmente em estado nativo, no alto Itacaiunas (municipio de Marabá-PA) nas áreas de mata baixa, como planta emergente, ultrapassando os 20 metros de altura, e também na mata virgem, rala e baixa, entre os municípios paraenses de Altamira e Itaituba (Cavalcante, 1976).

É encontrado ao longo dos tributários dos grandes rios, acompanhando os passos da penetração dos colonizadores, razão pela qual é observado em regiões distantes de sua área de dispersão natural, tais como Bahia, Rondônia, Acre, lquitos (Peru), San Carlos (Venezuela) e Cali (Colômbia). Encontram-se residências nas capitais ou interior que possuem exemplares visando a utilização familiar.

\subsection{Condições climáticas e edáficas para o cupuaçuzeiro}

O estudo do clima, assume grande importância, pois além de propiciar maior entendimento da dinâmica dos ecossistemas, onde é o maior determinante da vegetação, possibilita 0 melhor planejamento do uso da terra, compatibilizando a eficiência econômica com a capacidade de suporte do sistema solo-planta-atmosfera (Martorano et al., 1993).

Nos trópicos, a precipitação pluviométrica é o elemento meteorológico de maior variabilidade, sendo o principal fator utilizado na 
subdivisão de climas. Nesta área, ocorrem altos valores pluviométricos e as precipitações são, predominantemente, do tipo convectivas, em forma de pancadas e de curta duração.

Diniz et al. (1984), considerando as condições climáticas das áreas de ocorrência natural e de cultivo do cupuaçuzeiro, onde foi coletado germoplasma da espécie, verificaram as seguintes variações: temperatura média anual de $21,6^{\circ} \mathrm{C}$ a $27,5^{\circ} \mathrm{C}$; temperatura média mensal de $24,2^{\circ} \mathrm{C}$ a $28,2^{\circ} \mathrm{C}$; umidade relativa média anual de $77 \%$ a $88 \%$; umidade relativa média mensal de $64 \%$ a $93 \%$ e total pluviométrico anual de $1900 \mathrm{~mm}$ a $3100 \mathrm{~mm}$.

O cupuaçuzeiro, planta nativa da Região Amazônica, adaptado, portanto, às condições ambientais locais, prefere solos argilosos e com bastante húmus (Ducke, 1953). Contudo, crescimento satisfatório pode ser obtido em oxissolos ácidos, muito encontrados na região, e excelente crescimento quando plantado em solos de alta fertilidade, como os podzólicos eutróficos e os latossolos eutróficos (municipios de Uruçuca - BA, Jaru - RO e Nova Califórnia - AC). Também apresenta boa produtividade quando plantado nas várzeas altas, todavia não tolera cheias prolongadas. Comparado ao cacaueiro, membro da mesma família e gênero, o cupuaçuzeiro é menos exigente com relação às condições químicas de solo (Venturieri, G. A., 1993; Moraes et al., 1994).

\subsection{Caracterização botânica do cupuaçuzeiro}

Segundo Corrêa (1926/1978); Prance \& Silva (1975) e Cavalcante (1991), as características básicas do cupuaçuzeiro são as seguintes: 
Casca: granulosa fissurada, $2 \mathrm{~mm}$ de espessura, cinzenta, apresentando manchas brancas, lenticelosa, fibrosa; internamente rósea ou avermelhada, madeira pálida, com cheiro distinto.

Ramificação: ramos espessos, compridos, tomentosos, flexiveis, com indumento ferruginoso flocoso, deciduo, estrias longitudinais, retidoma esfolhiativo, tornando-se cinza, glabro, os ramos superiores ascendentes, os inferiores ternados, quase horizontais, cilíndricos.

Copa: irregular e pouco espessa.

Árvore: comumente de 6 a $10 \mathrm{~m}$ de altura, atingindo até $18 \mathrm{~m}$, de crescimento pseudo-apical, com tronco de 25 a $30 \mathrm{~cm}$ de diâmetro.

Folhas: simples, alternas, curto-pecioladas, pecíolo espesso, cilíndrico, ferrugíneo-tomentoso, 7 a $14 \mathrm{~mm}$ de comprimento, 2 a $5 \mathrm{~mm}$ de espessura; lâmina cartácea, oblonga ou elítico-oblonga, 20 a $35(15-60) \mathrm{cm}$ de comprimento, 6 a $11(5-16) \mathrm{cm}$ de largura, margem inteira ou ligeiramente sinuoso-dentada em direção ao ápice; ápice acuminado, acume de 1 a $2,5 \mathrm{~cm}$ de comprimento, glabra na face superior, verde, mais ou menos brilhante, ferrugineo-tomentosa na face inferior, pêlos estrelados; rede de nervuras filiformes, impressos na face superior, nervura principal proeminente no dorso, secundárias 9 a 10 pares proeminentes, ascendentes, anastomosando-se junto à margem.

Estipulas: sub-coriáceas, rígidas, 10 a $20 \mathrm{~mm}$ de comprimento, 3 a $6 \mathrm{~mm}$ de largura, persistentes, oblongas ou lanceoladooblongas, obtusas ou subagudas, nervo-estriadas, abundantemente lanato-tomentosas, tomento mais ou menos decíduo.

Inflorescência: pequena, axilar ou ramiflora, em cimeiras curtas, reduzidas, com 3 a 5 flores. 
Flores: hermafroditas, actinomorfas, diclamideas, heteroclamídeas e hipóginas com 3 brácteas no ápice do pedicelo, estreitamente lineares, tomentosas, 3 a $4 \mathrm{~mm}$ de comprimento; pedúnculos espessos, tomentosos, sem bractéolas, de 15 a $20 \mathrm{~mm}$ de comprimento; Moreira et al. (1993), observaram variação no comprimento e diâmetros do pedúnculos da flor entre as plantas, independente do tamanho da flor, sendo classificados em compridos e finos; cálice subcimbiforme; sépalas 5 valvares, espessas, carnosas, ovado-oblongas, subagudas, 14 a $15 \mathrm{~mm}$ de comprimento, 6 a $8 \mathrm{~mm}$ de largura, $1,5 \mathrm{~mm}$ de espessura, unidas no terço inferior, margem inflexa, ápice ligeiramente inflexo, estrelado tomentosas na parte externa, acráceas, verdes ou ferrugíneas, róseas ou avermelhadas no lado externo, lustrosas, pubescente-esbranquiçado na base com pequenos e espessos tricomas glandulares; pétalas 5, carnosas, com base arredondada-cuculadas, lâmina unguiculada, inseridas num disco globoso, espesso, carnoso, esbranquiçado; pétalas às vezes com riscos vermelhos, retusas no ápice, levemente emarginadas, truncadas lateralmente ciliadas na margem; tubo estaminal curto $(2,5 \mathrm{~mm})$, munido de pêlos glandulares; estaminóides 5 , petalóides, triangulares ou recurvado-lanceolados, iguais às pétalas em comprimento, entre os estames; o androceu em 2 verticilios de estames e estaminódios concrescidos; anteras com rimas longitudinais, dorsifixas; ovário súpero, pentagonal, 5 carpelos sincárpicos, pentalocular, multiovulado, placentação axilar; óvulos anátropos; estilete filiforme.

A flor do cupuaçuzeiro è pentâmera, porém Neves et al. (1992a), encontraram flor tetrâmera e hexâmera, fenômeno que não se refletiu em todas as flores da planta, caracterizando-se como um efeito fisiológico e não genético. 
Moreira et al. (1993), classificaram as flores em pequena, média e grande; observaram em flores médias e pentâmeras quatro tipos de abertura do cálice. Seguindo o sentido horário e tomando por base a primeira sépala que se desprendia, foram caracterizados os tipos de abertura, $(1+2+2$ - o mais comum), a primeira sépala desprende-se completamente, enquanto, as outras quatro formam dois pares de sépalas unidas; $(1+1+1+2)$, três sépalas livres e as outras duas formando um par; $(1+1+1+1+1)$, onde todas as cinco sépalas encontram-se livres e ( $2+3$ - o mais raro), onde se encontra somente um par e um trio de sépalas unidas, portanto sem sépalas livres. Como a abertura do cálice é um caráter quantitativo, portanto muito influenciado pelo ambiente, é compreensivel que ocorra grande variação no tipo de abertura da flor.

Os mesmos autores constataram, também, diferença significativa na forma das lâminas das pétalas de plantas que produzem frutos com sementes, as quais apresentam-se, proporcionalmente, mais largas que compridas, sendo o inverso encontrado nas lâminas das pétalas de plantas que produzem frutos sem sementes. Esta observação serve para diferenciar os dois tipos de planta.

Fruta: uma drupa, oblonga, elipsóide ou oboval, caindo da árvore quando madura, 16 a $25 \mathrm{~cm}$ de comprimento, por 10 a $12 \mathrm{~cm}$ de largura, pericarpo de $1 \mathrm{~cm}$ de espessura, epicarpo duro, lenhoso, 2 $\mathrm{mm}$ de espessura, coberto com uma delgada epiderme tomentosa, mesocarpo, $7 \mathrm{~mm}$ de espessura, carnoso, na maturidade apresenta película interna delgada, limitando a cavidade das sementes; sementes 20 a 50, seriadas, cada uma envolvida por uma polpa fibrosa amarelada, acidulada e distintamente aromática, derivada dos integumentos, 0 tegumento interno delicado, testa subcoriácea, castanho-claro. 


\subsection{Fenologia da floração e frutificação do cupuaçuzeiro}

O estudo de fenologia de uma planta, concentra-se no acompanhamento dos fenômenos de floração, frutificação e mudança foliar. Na maioria das plantas, o ambiente regula os fenômenos fenológicos, o que leva os individuos da espécie a florirem sincronicamente, fazendo com que a reprodução sexual seja realizada sob condições externas favoráveis.

A fenologia é definida como o estudo dos eventos sazonais temporais que ocorrem ao longo do ciclo vital da planta. A sazonalidade destes eventos é crítica para a sobrevivência e reprodução das espécies.

A floração de uma planta começa com a emissão da gema floral, desenvolvimento do botão floral, abertura da flor, antese (exposição dos órgãos florais à ação dos polinizadores) e o tempo de permanência da flor na planta.

O modelo fenológico do ciclo de vida da planta pode ser quantitativamente definido como uma distribuição estatística caracterizada por parâmetros como tempo de ocorrência (começo, meio e término), duração (extensão), sincronia (variância) e distorção (Rathcke \& Lacey, 1985).

Os fatores abióticos são frequentemente correlacionados com o tempo de floração. Em regiões temperadas, as baixas temperaturas na primavera e outono podem limitar a estação de florescimento, embora algumas plantas anemófilas (plantas que usam o vento como transportador de pólen para realização da polinização) e plantas que ocorrem em grandes altitudes floresçam durante o frio ou sob a neve. Nas espécies neotropicais sazonais, a maior parte das ervas e 
arbustos florescem na estação chuvosa, porém muitas árvores florescem tanto na estação seca como na estação chuvosa (Frankie et al., 1974). Em contraste, em floresta não sazonal, não ocorre apenas um pico de floração e as espécies florescem mais que uma vez no ano (Opler et al., 1980; Rabinowitz et al., 1981).

Os fatores ambientais influenciam diretamente as polinizações por afetar a produção de flores e indiretamente por interferir no comportamento dos vetores de pólen.

Segundo Janzen (1967), na região dos trópicos que apresenta sazonalidade, durante a estação seca, há maior número de horas de luz solar diária, devido à ausência de nuvens. Muitas espécies de insetos que visitam as flores, especialmente abelhas, mostram redução na atividade durante os dias ou horas nublados, consequentemente diminuindo a polinização.

Conforme Prance \& Silva (1975), o cupuaçuzeiro floresce no período de julho a dezembro e frutifica de agosto a abril. Calzavara et al. (1984), constataram o início do aparecimento das flores, no mês de junho e o final em março do ano seguinte, com maior intensidade entre os meses de novembro a janeiro, na floração dos anos de $1982-83$ e 1983-84.

De acordo, com Neves et al. (1993a), trabalhando com dados fenológicos de 1989, a floração iniciou-se na primeira quinzena de junho e a maior intensidade de florescimento ocorreu no periodo compreendido entre a segunda quinzena de agosto e a primeira de outubro. A frutificação começou na segunda quinzena de junho, sendo que a maior frequência de frutos iniciados foi no mês de agosto; os primeiros frutos maduros caíram na primeira quinzena de dezembro. $O$ periodo de maior emissão de brotos foliares foi na primeira quinzena de 
julho, portanto no final do periodo das chuvas, enquanto que na segunda quinzena de setembro, no meio do periodo seco, houve a maior abscisão de folhas senescidas. Esses dados mostram a sincronia dos eventos fenológicos, com as variáveis meteorológicas. O florescimento na estação seca, também foi detectado por Venturieri (1994).

Nas citações anteriores, observa-se como ponto comum, a ocorrência da floração do cupuaçuzeiro no período mais seco, período de maior atividade por parte dos polinizadores, principalmente, os insetos; enquanto que o desenvolvimento dos frutos, ocorre no período das chuvas, onde as plantas necessitam de muita água para o bom desempenho da atividade fisiológica de maturação dos frutos. Estes resultados mostram uma forte interação planta-ambiente, a qual demonstra a adaptação da espécie às condições ambientais do trópico úmido.

\subsection{Biologia floral do cupuaçuzeiro}

A biologia floral está inserida em um amplo contexto, dentro da biologia reprodutiva, abrangendo todos os eventos que ocorrem na flor, desde a formação das gemas florais até a fecundação.

\subsubsection{Estádios da floração e frutificação}

Neves et al. (1991, 1993b), dividiram em 20 estádios (fases) o desenvolvimento dos órgãos reprodutivos do cupuaçuzeiro até a queda do fruto, sendo um estádio caracterizado pela presença de bráctea florifera; quatro por botões completamente fechados; quatro por botões fechados com abertura(s) no cálice; um por flor semi-aberta; seis 
por flores abertas e quatro referentes aos estádios de frutos imaturos e maduros. Entre os estádios destacam-se o 2 - BF2-3 (botão fechado entre 2 a $3 \mathrm{~mm}$ de diâmetro) usado nos estudos de contagem de cromossomos na metáfase da meiose, estádio 4 - BF $\geqslant 12 \mathrm{~mm}$ (botão fechado igual ou maior que 12 milimetros de diâmetro), antes de iniciar a receptibilidade do estigma e deiscência da antera, estádio 8 - BF3A (botão fechado com três aberturas no cálice), utilizado nos trabalhos de polinização artificial, pois o estilete e estigma estão receptiveis e já ocorreu a liberação do pólen, e a flor encontra-se completamente fechada, sem qualquer possibilidade de contaminação por pólen indesejável, estádio 10 - FSA (flor semi-aberta), onde ocorre a antese através da liberação das lâminas das pétalas, permitindo o acesso dos polinizadores aos órgãos reprodutivos; estádio 12 - FADA (flor aberta no dia anterior), onde tem início o processo de inviabilidade do estigma e estilete; estádio 15 - FAEC (flor aberta escura completa) que indica se houve a fertilização, pois o ovário encontra-se em maior tamanho, coloração rósea e pedúnculo mais grosso que o normal, permanecendo verde; estádio 18 - FRISEL (fruto imaturo com endosperma líquido) onde ocorre o maior percentual de queda de frutos imaturos e o estádio 20 FRM (fruto maduro), sendo que o fruto pode estar na planta ou no chão.

Silva et al. (1993a), estudando variedades que produzem frutos com sementes, constataram que o desenvolvimento do botão floral em flor aberta ocorre em 25 dias, com amplitude de 19 a 34 dias. No dia anterior à abertura, os botões apresentavam, em média, $13,42 \mathrm{~mm}$ de comprimento e $13,06 \mathrm{~mm}$ de diâmetro e cerca de $23,18 \%$ dos botões iniciados, caiam antes de completarem o desenvolvimento, enquanto que em plantas que produzem frutos sem sementes, o período 
de desenvolvimento do botão foi de 24 dias, e o percentual de botões que foram derrubados antes de completarem o ciclo foi de $34,24 \%$.

\subsubsection{Abertura da flor}

$\mathrm{Na}$ flor do cupuaçuzeiro a antese ocorre logo após o inicio da abertura da flor, pois os órgãos reprodutivos são expostos à ação do polinizador logo que a flor começa a abrir, no estádio 10 - FSA (Neves et al., 1993b).

A maior parte das flores, está completamente aberta no período de $17 \mathrm{hàs} 18 \mathrm{~h}$. No dia da abertura da flor, pela manhã, o botão floral apresenta estrias esbranquiçadas na região de união das sépalas, servindo, dessa forma, como um indicativo da futura abertura da flor, que ocorrerá até o final da tarde. Esta característica é de grande interesse para o desenvolvimento da prática de polinização artificial (Neves et al., 1992c; Venturieri, 1993 e 1994).

\subsubsection{Receptibilidade do estigma e estilete da flor}

$\mathrm{Na}$ flor do cupuaçuzeiro, a exemplo da flor do milho (Zea mays), a fecundação ocorre ao longo do estilete e no estigma, sendo que Silva et al. (1993b), estudando oito estádios do desenvolvimento de botões e flores, constataram que a viabilidade segue uma curva normal entre o estádio 6 - BF1A (Botão fechado com uma abertura no cálice) e o estádio 12 - FADA. Portanto, para que a polinização natural seja satisfatória, esta deve ocorrer no período de $16 \mathrm{~h}$ no estádio 10 - FSA às 9h no estádio 12 - FADA, do dia seguinte. 
Venturieri (1994) constatou deiscência da antera e receptibilidade do estigma, tão logo as flores estejam completamente abertas, permanecendo o estigma receptivo até às $10 \mathrm{~h}$ da manhã do dia seguinte.

Independente da receptibilidade do estigma durar até Th ou $10 \mathrm{~h}$ do dia seguinte da abertura da flor, o importante é a orientação que esses experimentos propiciam para a condução da polinização artificial, a qual preferencialmente deverá ser desempenhada, no periodo de $16 \mathrm{~h}$ às $18 \mathrm{~h}$, periodo da maior intensidade de abertura da flor, portanto facilitando a operacionalização das polinizações.

\subsubsection{Cor da flor}

Foi constatado que as flores do cupuaçuzeiro apresentam grande diversidade de cores, principalmente, nas lâminas das pétalas. Trabalhando com plantas de origem desconhecida, Neves et al. (1992d), detectaram 16 intensidades diferentes de pigmentação, sendo as mais comuns: marrom, róseo-avermelhada, rósea, vermelha e púrpura. Embora na maioria das vezes o caráter cor de flor seja classificado como qualitativo, serve como referencial da variabilidade genética dentro da espécie.

\subsubsection{Exalação de odor}

A comprovação da exalação de odor de flores, pelo olfato, embora seja uma método empírico e não apresente valor científico, por ser subjetivo a cada pessoa, é bastante usado, sendo utilizado por Neves et al. (1993b), que detectaram liberação de odor com maior 
intensidade no estádio 12 - FADA do cupuaçuzeiro. Venturieri (1994) constatou forte exalação de odor quando as flores apresentavam-se completamente abertas e pequeno aumento nas primeiras horas da manhã do dia seguinte.

\subsubsection{Estudos palinológicos}

A palinologia apresentou grande contribuição, ao estudo do gênero Theobroma, pois foi com base em estudos dessa natureza, que houve a reclassificação da espécie Theobroma mariae, do gênero Theobroma para o gênero Herrania, atualmente designada de Herrania mariae.

Neves et al. (1992b), observaram que o grão de pólen do cupuaçuzeiro é suboblasto, tri-colporado e de superficie reticulada. A maior viabilidade ocorreu no estádio 10 - FSA.

\subsubsection{Polinização natural e insetos polinizadores}

Segundo Faegri \& van der Pijl (1979), somente nas angiospermas, a polinização natural é caracterizada por três fases, que são: liberação do pólen da parte masculina da flor, transferência do pólen da parte masculina para a parte feminina, e deposição do pólen sobre estigma compativel para que o tubo polínico cresça e encontre o óvulo (processo de fecundação). Portanto, em plantas auto-incompativeis não ocorre polinização satisfatória. Porém, Inouye et al. (1994), apresentaram um conceito atualmente mais utilizado, onde mantêm as três fases, com alteração da última. Excluem o processo de fecundação da polinização, e consideram todos os eventos que ocorrem após a deposição do pólen no 
estigma, a exemplo de crescimento do tubo polínico, dupla fertilização e inicio do desenvolvimento de semente e fruto, como processos póspolinização.

Dessa forma, a polinização satisfatória é aquela realizada com quantidade de grãos de pólen capaz de fertilizar um número de óvulos que possibilite o desenvolvimento do fruto.

Nas espécies que utilizam animais para a realização da polinização, é necessário que haja atrativos florais, a recompensa para os polinizadores. Para Baker (1983), entre os produtos de recompensa, podem ser incluidos os químicos provedores de energia e os químicos constituintes do corpo. As abelhas utilizam químicos voláteis para a marcação de território ou mesmo para atrair outras abelhas para a área.

Faegri \& van der Pijl (1979) classificaram os atrativos florais em primários (pólen, néctar, óleos e outras substâncias) e secundários (odor e atração visual), pela ordem de importância; os primeiros são considerados mais importantes por estarem ligados diretamente às necessidades nutricionais. A flor do cupuaçuzeiro apresenta as lâminas das pétalas variando desde completamente despigmentada (albina) a forte pigmentação (vermelha) (Neves et al., 1992). O maior atrativo perece ser o pólen que é produzido em grande quantidade. A flor não apresenta nectários, mas apresenta exalação de odor segundo Neves et al. (1993b) e Venturieri (1994).

Nas espécies que necessitam de vetores biológicos para promoverem o fluxo de pólen, a identificação dos polinizadores é um fator de grande importância, pois, como a polinização é um elemento essencial para a produção, a manipulação das populações desses polinizadores consiste numa forma para aumentar a produtividade. 
O cupuaçuzeiro é uma espécie visitada por muitos insetos, o que dificulta a identificação e separação dos polinizadores, predadores e pilhadores. Segundo Falcão \& Lleras (1983), o cupuaçuzeiro é visitado por inúmeras abelhas, sendo as mais frequentes Frieseomelitta silvestrii faceta Moure, Pratrigona impuctata Ducke e Apis melifera adansonii, sendo menos comuns Ptilotrigona lurida Smith e Tetragona clavipes Fabricius, coletadas dentro das flores. A última foi observada perfurando as cúculas das pétalas, concordando com as observações de Silva (1976) de que a polinização do cupuaçuzeiro não é feita somente por um polinizador específico, mas por várias espécies de abelhas que contribuem em diferentes graus.

Neves et al. (1993c), constataram a presença de um curculionideo em $18 \%$ das flores estudadas, com média de 1,23 insetos por flor, com amplitude de 0 a 4 . Em 97 insetos encontrados, 54,6\% apresentavam pólen de cupuaçuzeiro e de outras espécies aderido ao corpo. Esses insetos na fase larval, provocam danos ao botão floral.

Segundo Venturieri (1993; 1994), as abelhas sem ferrão Plebeia minima e Trigonisca pediculana, visitam as flores do cupuaçuzeiro, porém a primeira é considerada o polinizador efetivo, sendo as formigas e o coleóptero "gorgulho" (Baris $\mathrm{sp}$.) considerados polinizadores secundários, pois não promovem polinização efetiva.

\subsection{Sistema reprodutivo e sexualidade floral em plantas arbóreas tropicais.}

Atualmente, a sexualidade floral e o sistema de incompatibilidade são os componentes do sistema reprodutivo que têm recebido maior atenção por parte dos pesquisadores. 
Aubréville (1938), pesquisando a flora de uma floresta primitiva em Massa Mé, Oeste da África, constatou que $74 \%$ das espécies apresentavam flores hermafroditas, 15\% monóicas e 11\% dióicas, sendo resultado inverso encontrado para plantas de florestas temperadas. Com base nesses resultados e em estudos feitos em árvores isoladas devido à destruição das florestas e em plantas cultivadas em jardins botânicos, foi sugerido que para espécies arbóreas tropicais, a endogamia era comum, sendo, portanto, predominantemente autoférteis (East, 1940; Baker, dados não publicados citados por Baker, 1959).

Corner (1954), sugeriu que árvores da floresta tropical úmida poderiam ser de autofertilização, pois apresentavam floração assincrônica e mobilidade dos polinizadores limitada à pequenas distâncias. Baker (1959) também propôs que na complexa floresta úmida, a adequada movimentação dos polinizadores entre as árvores poderia ser impedida. Como resultado, a maior parte das árvores poderia ser de autofertilização e endógama. Fedorov (1966) argumentou em favor da autogamia e endogamia com base no florescimento assincrônico, isolamento espacial dos indivíduos e baixa densidade populacional das árvores da floresta tropical úmida. Em contrapartida, Ashton (1969) expressou opinião em favor da fertilização cruzada e Janzen (1971) mostrou que certos polinizadores podem visitar plantas à longa distância e portanto transportam pólen entre individuos da mesma espécie que estão à grandes distâncias.

O trabalho de Bawa (1974) constatando que a maior parte das espécies, isto é ao redor de $76 \%$ (54\% auto-incompatíveis e $22 \%$ dióicas) eram de fertilização cruzada, portanto, obrigatoriamente alógamas, eliminou completamente qualquer dúvida a respeito do sistema reprodutivo predominante na floresta tropical. 
Zapata \& Arroyo (1978) relataram maiores taxas de fertilização cruzada do que as encontradas por Bawa (1974), analisando espécies de floresta secundária decídua em Miranda, Venezuela.

Bullock (1985) estudando a sexualidade floral de uma vegetação, predominantemente tropical decídua, em Chamela no México, constatou que em 188 árvores estudadas 57,9\% eram hermafroditas, sendo $53,7 \%$ monostilicas e $4,2 \%$ heterostílicas, $2,6 \%$ andromonóicas, $1,1 \%$ poligamonóicas, $12,2 \%$ monóicas, $2,1 \%$ ginodióicas e $23,9 \%$ dióicas. Por outro lado, $76 \%$ das árvores e arbustos apresentavam autoincompatibilidade.

Os estudos desenvolvidos sobre a sexualidade floral e sistema reprodutivo nos trópicos, vêm sendo desenvolvidos basicamente em plantas arbóreas. Croat (1979), trabalhando em floresta tropical úmida da liha Barro Colorado, Panamá, incluiu a flora inteira, e constatou que as árvores não constituíam $50 \%$ da flora local, indicando que estudar apenas o sistema reprodutivo de espécies arbóreas, não serve como referencial, para extrapolar para toda a flora tropical.

A descoberta de apomixia (formação de sementes sem a junção dos gametas masculino e feminino) em algumas árvores na Malásia (Kaur et al., 1978) e baixa incidência de auto-incompatibilidade nas plantas de floresta fria da Venezuela (Sobrevila \& Arroyo, 1982), indicam a possibilidade de mudança na forma como as plantas transmitem seus genes para os descendentes na floresta tropical como um todo, demonstrando que as informações a respeito do sistema reprodutivo obtidas até agora, são poucas para se formular conclusões gerais para todas as florestas tropicais.

Bawa et al. (1985), que estudaram o sistema de polinização de 143 espécies da floresta tropical úmida da Costa Rica, 
concluíram que as abelhas médias e grandes (principalmente Anthophoridae) são as polinizadoras mais frequentes, seguidas pelas mariposas, diversos insetos de pequeno tamanho e abelhas pequenas.

Bawa \& Opler (1975), observaram que a dioicia está associada à polinização por insetos pequenos, pois $66 \%$ das espécies dióicas eram polinizadas por diversos insetos e abelhas de pequeno tamanho. Entre as espécies monóicas, excluindo sete que eram polinizadas por vespas, $75 \%$ eram polinizadas por diversos pequenos insetos ou pequenas abelhas.

Portanto, as citações anteriores demonstram que praticamente não há dúvidas que o hermafroditismo é o sistema sexual predominante nas espécies que compõem a floresta tropical, porém quanto ao sistema reprodutivo, ainda é necessário mais estudos em ecossistemas como os existentes na Região Amazônica, para que se possa obter informações mais abrangentes.

\section{8. Hipóteses que se propõem a explicar a proporção flor:fruto.}

$O$ percentual de flores que se desenvolve em frutos maduros, ou seja, o nivel de frutificação, é um fator altamente relevante para o sucesso reprodutivo das plantas. Nos últimos anos, autores como Stephenson (1981); (1984); Sutherland \& Delph (1984); Sutherland (1986), (1987) têm relatado baixo nível de frutificação (alta taxa de abscisão) em inúmeras plantas hermafroditas. Nestas plantas, parece estar havendo um grande investimento de recursos em flores que não produzem frutos. As espécies tropicais são propensas a apresentarem baixa frutificação em relação à produção de flores. 
As principais hipóteses propostas para explicar 0 "excesso" de produção de flores, em plantas hermafroditas, em relação a produção de frutos, são:

Hipótese de atração: proposta por Willson \& Rathcke, (1974) e adotada por Stephenson (1979) e Schemske (1980), prediz que a produção de flores em "excesso" é vantajosa, pois aumenta a atratividade das plantas para os polinizadores e, consequentemente, aumenta a taxa de polinização.

Hipótese de aborto seletivo: proposta por Stephenson (1981); Stephenson \& Bertin (1983); Kozlowsky \& Stearns (1989), prediz que produção de flores em "excesso" permite a planta abortar seletivamente os frutos. A planta em que todas as flores recebem polinização satisfatória, pode não apresentar capacidade suporte para sustentar o desenvolvimento de todos os frutos, devido à insuficiência de recursos, espaço ou restrições físicas. A limitação de recursos pode causar aborto de muitos óvulos e ovários em desenvolvimento (Stephenson, 1981) e ser uma forma de escolha do cruzamento em plantas (Janzen, 1977).

Hipótese da macho função: proposta por Willson \& Rathcke (1974); Queller (1983); Sutherland \& Delph (1984); Bertin (1988), prediz que embora a planta seja hermafrodita, parte das flores atua como se fosse masculina e somente doam pólen, portanto não contribuem para a aptidão feminina.

Hipótese de disponibilidade de recurso: proposta por Stephenson (1981) e Aker (1982), prediz que a produção de flores em excesso permite à planta explorar condições favoráveis esporádicas em termos de disponibilidade de recurso.

Hipótese de reserva de ovário: proposta por Ehrlén (1991), prediz que a produção de flores em excesso pode constituir uma reserva 
suplementar de ovários, no caso de alta mortalidade durante o periodo da floração.

Hipótese de limitação de polinizador: proposta por Schemske (1980); Willson \& Schemske (1980) e Howell \& Roth (1981), em plantas auto-incompativeis pode refletir a baixa densidade de polinizador ou a baixa taxa de visita do polinizador.

As hipóteses propostas anteriormente, para explicar a alta relação flor:fluto não são mutuamente exclusivas, ou seja a constatação de uma não significa que outros fatores não estejam presentes, pelo contrário o que se tem observado é o efeito de dois ou mais fatores interagindo para manter a frutificação baixa.

\subsection{Influência ambiental sobre o sistema reprodutivo.}

Embora a taxa de cruzamento esteja sob controle genético, a estrutura de cruzamento da maior parte das espécies é plástica e sujeita à influência ambiental. Obviamente, a estrutura de cruzamento das plantas que utilizam insetos como vetores de pólen é afetada pelo número de polinizadores disponiveis, modelo de organização social e número de espécies na área que são servidas por um mesmo polinizador.

O sistema reprodutivo das espécies hermafroditas é determinado por herança de fatores genéticos (grau de autocompatibilidade) e fatores ecológicos (movimento do polinizador, fenologia floral, densidade de população) (Murawski \& Hamrick, 1991).

Segundo Iglich (1980) citado por Clegg (1980), em Acer rubrum, espécie polinizada por insetos, existem as três formas sexuais. No início do período da reprodução, a frequência de flores 
hermafroditas é baixa, entretanto com a aproximação do final da estação de reprodução, a frequência de flores hermafroditas aumenta, presumivelmente aumentando a oportunidade para a autofertilização na ausência de polinizadores.

Koptur (1984), pesquisando sete espécies de Inga, constatou que as espécies deste gênero eram auto-incompativeis e que os cruzamentos intra-específicos foram mais satisfatórios quando a fonte de pólen estava a mais de $1 \mathrm{~km}$.

Estudos visando quantificar a taxa de cruzamento em Avena barbata, Bromus mollis e Hordeum spontaneum, em diferentes habitats, constataram que o grau de aridez do ambiente está correlacionado com o aumento das taxas de autofertilização. Por outro lado, Phillips \& Brown (1977) constataram que a altitude apresenta influência na taxa de cruzamento de Eucalyptus pauciflora.

Como o sistema de cruzamento é afetado por fatores ambientais (Barrett \& Eckert, 1990; Mitton, 1992), e por ser controlado geneticamente, está sujeito à seleção. Consequentemente, pode diferir entre as populações (Lyons \& Antonovics, 1991), assim como dentro de populações, indivíduos podem exibir diferenças na quantidade de autofertilização ou fertilização cruzada, conforme constatado por Clegg \& Epperson (1985).

As diferenças na mensuração da taxa de fertilização cruzada entre vários habitats demonstram a influência ambiental sobre a estrutura reprodutiva. Ellstrand et al. (1978), constataram em Helianthus annuus que a estimativa da taxa de cruzamento está correlacionada com a densidade das plantas. Em Canavanillesia platinafolia individuos isolados pela não floração de plantas próximas, apresentaram taxa elevada de autofertilização (Murawski \& Hamrick, 1992a). 
Segundo Thomson \& Stratton (1985), o grau de exposição estilar afeta a porcentagem de pólen que cai sobre o estigma, demonstrando, dessa forma, a influência da morfologia floral no sistema reprodutivo.

Portanto, uma vez que o sistema reprodutivo sofre influência do ambiente, no final do período de florescimento uma espécie pode apresentar elevada taxa de autofertilização, embora no pico fosse, predominantemente de fertilização cruzada (Kearns \& Inouye, 1993).

\subsection{Análise do sistema reprodutivo através de marcadores isoenzimáticos.}

Atualmente, os estudos de determinação do sistema reprodutivo estão sendo, basicamente, realizados através da utilização de marcadores isoenzimáticos e moleculares.

Análise do padrão eletroforético de progênies tem demonstrado que o sistema de cruzamento das espécies que compõem a floresta tropical varia de fertilização cruzada à autofertilização, porém em geral, as espécies são predominantemente ou completamente de fertilização cruzada (O'Malley \& Bawa, 1987; O'Malley et al., 1988; Murawski \& Hamrick, 1991, 1992a, b).

Murawski et al. (1994), avaliando o sistema de cruzamento através de padrões isoenzimáticos de Shorea congestiflora e S. trapezifolia, no primeiro trabalho com marcadores isoenzimáticos realizado no Velho Mundo, constataram que $87 \%$ das sementes de $S$. congestiflora resultaram de fertilização cruzada, enquanto que em $S$. trapezifolia havia mistura do sistema de cruzamento, com $54 \%$ e $62 \%$ nos dois anos consecutivos de realização do trabalho. 
Bawa \& O'Malley (1987), utilizando-se de marcadores isoenzimáticos detectaram que Pithecellobium pedicellare apresenta $96,4 \%$ de fertilização cruzada.

Loveless \& Hamrick (1987) analisando o sistema reprodutivo de 124 espécies, detectaram correlação altamente significativa entre o sistema reprodutivo e o coeficiente de diferenciação genética $(C D G)$, sendo que espécies exogâmicas apresentaram valores mais baixos que as espécies de sistema reprodutivo misto ou endogâmicas.

\subsection{Sistema de auto-incompatibilidade (SAI)}

A auto-incompatibilidade é a incapacidade de uma planta hermafrodita ou monóica produzir sementes viáveis após ser autopolinizada. Este é o principal e mais eficiente mecanismo para evitar a autofertilização. O sistema de auto-incompatibilidade foi observado em 19 ordens e 71 famílias, incluindo dicotiledôneas e monocotiledôneas, plantas de todas as regiōes geográficas e todas as formas de vida (Brewbaker, 1957).

O sistema de auto-incompatibilidade tem sido mencionado como uma forma de evitar a endogamia, justificativa para sua manutenção e evolução nas plantas. Porém Olmstead (1986), considerando a relação entre o sistema reprodutivo de espécies autoincompativeis e o nivel de endogamia nas populações, propôs que a manutenção e evolução do sistema de auto-incompatibilidade pode ter ocorrido independente do nível de endogamia existente nas populações como um todo. Isto porque, a autofertilização somente apresenta pequena influência sobre o nível de endogamia, quando comparado ao 
efeito do tamanho da população. Já que muitas plantas são caracterizadas pelo pequeno tamanho efetivo da população e considerável subestrutura genética, elas provavelmente experimentam considerável endogamia.

O mesmo autor argumenta que a endogamia tem efeito benéfico, pois reduz o custo da meiose, mantém o complexo gênico coadaptado, e existe em nível ótimo na população. Seguindo esta pressuposição, a manutenção da auto-incompatibilidade resulta, primariamente, de diferenças na relativa adaptação da progênie de autofertilização e de fertilização cruzada, não de qualquer influência positiva conduzida pela exogamia.

A comprovação desta teoria foi obtida por Warren et al. (1995a) que, estudando uma população de cacaueiro, formada por número igual de plantas auto-incompativeis e autocompativeis, comprovaram que as plântulas originadas das plantas autocompativeis eram mais fracas que as originadas de plantas auto-incompatíveis, havendo consequentemente, na geração seguinte, maior número das plantas auto-incompatíveis, que autocompativeis.

Campbell (1986) e Holsinger (1988) questionaram a importância da depressão endogâmica para a evolução do sistema reprodutivo. Eles mostraram que o grau de ligação entre locos controlando a adaptação e um loco controlando a taxa de autofertilização pode ser mais importante do que a depressão endogâmica. Através de um modelo genético determinístico, Damgaard et al. (1992) mostraram que autofertilização parcial pode ser uma ótima estratégia de reprodução.

Bawa (1974) relata que a prevalecência do sistema de auto-incompatibilidade e dioicia, em árvores da floresta tropical é, 
provavelmente, devido à pressão seletiva para manter a variação genética.

Quando há predomínio do sistema de autoincompatibilidade, na maior parte das espécies de uma floresta, é indício de que as barreiras que evitam a autofertilização são de origem genética e não morfológica, conforme constatado por Bawa (1974) em florestas tropicais.

O mesmo autor observou variação no sistema reprodutivo em diversas espécies auto-incompativeis, sendo que um ou dois individuos frutificaram quando autopolinizados. Os frutos apresentavam sementes bem desenvolvidas, provavelmente resultado da quebra do sistema de incompatibilidade e não da contaminação por pólen estrangeiro. Quando os experimentos foram repetidos, as flores autopolinizadas na mesma planta novamente desenvolveram-se em fruto.

Mendoza (1965) pesquisando o sistema reprodutivo de Cordia alliodora e Bryndum \& Hedegart (1969), trabalhando com Tectona grandis detectaram completa auto-incompatibilidade.

A principal vantagem do sistema de autocompatibilidade é o aumento da probabilidade de ocorrer polinização satisfatória, 0 que pode ser consideravelmente vantajoso na impossibilidade da polinização ou falta de polinizadores (Rick, 1966). O aumento da probabilidade de polinização satisfatória pode também promover menor custo da reprodução para produzir o mesmo número de frutos, dessa forma, as espécies autocompatíveis podem dar-se ao luxo de produzir menor número de flores para produzirem o mesmo número de frutos que as auto-incompativeis. Isto porém, nem sempre acontece pois, em cacaueiro, tem sido observado que plantas autocompativeis levam vantagem no número de frutos iniciados, mas com relação ao número de 
frutos maduros não têm apresentado diferença significativa para plantas auto-incompativeis (Warren et al. 1995a, b).

\subsubsection{Tipos de sistema de auto-incompatibilidade (SAI)}

Os sistemas de auto-incompatibilidade podem ser divididos em dois grupos distintos: o SAl gametofitico, no qual o fenótipo da incompatibilidade é determinado por seu próprio genótipo haplóide e o SAl esporofítico no qual o fenótipo da incompatibilidade é governado pelo genótipo do parental produtor do pólen. A diferença entre os dois sistemas está no tempo de ação do gene $\mathbf{S}$, que no sistema esporofítico é pré-meiótico, portanto antes da individualização na tétrade, enquanto que no sistema gametofítico ocorre após a primeira metáfase da meiose na célula mãe do grão de pólen (Nettancourt, 1977).

O SAl esporofítico é dividido em sistema homomórfico (mesma morfologia) e heteromórfico (morfologicamente diferente). O SAI esporofitico heteromórfico apresenta a antera e estigma em planos diferentes, sendo os principais tipos conhecidos, como: distilia, que apresenta os órgãos florais (antera e estigma) em dois planos, sendo que as espécies que apresentam este sistema de auto-incompatibilidade formam dois grupos de cruzamento; e a tristilia em que os órgãos florais estão dispostos em três planos, e as espécies que apresentam este sistema formam três grupos de cruzamentos. As espécies que apresentam o SAI heteromórfico exibem menor oportunidade de cruzamentos, causando, dessa forma, maior custo de energia para as espécies que o possuem, do que o SAl esporofítico homomórfico.

Uma característica do SAl esporofitico de grande interesse para o melhoramento de plantas, é a possibilidade de 
autofertilização e produção de linhagens endogâmicas nas espécies que o possuem, quando a planta é heterozigota e apresenta inversão de dominância na parte masculina e feminina, ou seja, quando o alelo é dominante no pólen e recessivo no ovário (Ramalho et al., 1995).

O SAl esporofítico homomórfico é governado por apenas um loco (S) com muitos alelos controlando a incompatibilidade. No sistema heteromórfico, a distilia é controlada por apenas um loco com dois alelos e a tristilia por dois locos, cada um com dois alelos e havendo epistasia entre os locos (Ganders, 1979).

Apesar da variação no modelo da herança entre os SAl, cada um possui características distintas. Em geral, no sistema gametofítico o grão de pólen é binucleado e o crescimento do tubo polinico é inibido no estilete, enquanto no sistema esporofítico o pólen é trinucleado e a rejeição ocorre na superfície do estigma (Nettancourt, 1977).

Sutherland (1986), revisando o estudo do sistema reprodutivo de 447 espécies concluiu que a compatibilidade é o principal fator controlador da frutificação nas plantas. Planta autocompativel tem significativamente média superior de frutificação.

O SAl esporofitico pode apresentar área de rejeição no ovário. Os primeiros estudos de crescimento do tubo polínico em espécie auto-incompatível sugeriram que a inibição do tubo polínico do próprio pólen ocorre no ovário, sendo bem conhecido o caso do cacaueiro (Cope, 1962).

Seavey \& Bawa (1986) revisaram sobre a frequência de ocorrência, natureza e significância funcional da incompatibilidade no ovário, a qual denominaram de auto-incompatibilidade com ação tardia, e 
constataram que a frequência de ocorrência é maior que citada em literatura.

Os mesmos autores classificaram o sistema de incompatibilidade com reação tardia em quatro categorias: 1 - inibição do tubo polínico no ovário antes do óvulo ser atingido; 2 - inibição préfertilização do óvulo; 3 - rejeição pós-zigótica e 4 - inibição no óvulo, embora os detalhes citológicos ainda não sejam muito claros. Portanto, a inibição do tubo polínico, no ovário, pode ser pré ou pós-zigótica. A rejeição pós-zigótica é frequentemente excluída da definição de autoincompatibilidade, em virtude da dificuldade de distinção com os efeitos causados pela depressão endogâmica, que é o aborto embrionário devido à ação de genes letais recessivos, descobertos pela autofertilização. Muitos autores, trabalhando com várias espécies de diversas familias detectaram o fenômeno, como em Cola nitida (Jacob, 1973), Sterculia chicha (Taroda \& Gibbs, 1982), seringueira (Sedgley \& Attanayake, 1988) e azaléia (Rhododendron prinophyllum) (Padrutt et al., 1992).

\subsubsection{Modificação e perda do sistema de auto-incompatibilidade} (SAI).

Estudos do sistema reprodutivo relatam evidências da perda do SAI. A tendência do gene do loco da auto-incompatibilidade mutar para autocompatibilidade tem sido observado no sistema homomórfico e heteromórfico (Lewis, 1951; Nettancourt, 1977; Shore \& Barrett, 1986).

Vários tipos de modificações levam à ocorrência de autocompatibilidade, como: mutação do(s) gene(s) da incompatibilidade, alteração do conhecimento genético em função dos alelos $\mathbf{S}$, ocorrência 
de poliploidia em sistema gametofitico (excluindo Ranunculus, Beta e monocotiledôneas), e formação de homostilia em espécies distilicas como um resultado do crossing-over no supergene controlando a sindrome da heterostilia. Se o mutante autocompativel vai ou não se estabelecer e difundir-se, depende da sua habilidade em competir com seus progenitores de fertilização cruzada para se estabelecer no novo ambiente (Jain, 1976; Lloyd, 1980). Normalmente, a depressão endogâmica resultante da alta carga genética, é o principal fator restringindo a expansão do mutante, principalmente se o progenitor que Ihe deu origem é originado de uma população de tamanho grande.

Em espécies de fertilização cruzada que apresentam polinizador esporádico, e que falham numa escala de tempo de 100 gerações, a seleção promove mudanças no modo de reprodução com alto grau de autofertilização, a qual reduz a carga genética e a magnitude da depressão endogâmica (Lande \& Schemske, 1985).

Hamilton \& Mitchell-Olds (1994) estimando o sistema reprodutivo de Arabis fecunda, planta perene hermafrodita, detectaram $39 \%$ de autofertilização, porém as progênies resultantes apresentavam depressão endogâmica e a mistura de sistema de cruzamento evidencia que efeitos deletérios da autofertilização são mantidos através de altas taxas de mutação de pequeno efeito, que provavelmente estavam encobertas pelo alto grau de heterozigosidade.

A mutação no loco de incompatibilidade, tornando-o autocompatível não, necessariamente, significa que $\mathrm{o}$ indivíduo será autopolinizado, como observado na espécie Astianthus viminalis, que embora autocompativel, apresentou resultado negativo para os testes de autogamia e apomixia (Bullock, 1985). O grau de autofertilização depende de fatores, como morfologia floral e abundância de vetores de pólen. 
A perda de incompatibilidade no SIA homomórfico, foi documentado em Leavenworthia crassa e L. alabamica que exibem população com auto-incompatibilidade e autocompatibilidade. A população autocompativel desenvolveu adaptações, como modificação da antera e pequeno tamanho de flor, que aumentam a eficiência da autopolinização (Lloyd, 1965).

Em certos casos, a perda da auto-incompatibilidade pode estar associada com a especiação, como proposto para Stephanomeria mallheurensis (Gottlieb, 1973) e Lasthenia maritima (Crawford et al., 1985). Em ambos os casos, parece que modificações genéticas no loco que controla a auto-incompatibilidade esporofitica desencadeou eventos levando ao isolamento reprodutivo.

Indicação de possivel mudança de autoincompatibilidade para autocompatibilidade em cacaueiro foi obtida por Pound (1932), que sugeriu existir fatores fisiológicos que modificariam a expressão genética da incompatibilidade em certas estações do ano e propôs o termo autocompatibilidade condicional. A metodologia empregada para a avaliação do resultado da frutificação, foi criticada por Voelcker $(1937,1938)$, quando estabeleceu que a contagem dos frutos após seis dias da polinização poderia dar uma falsa impressão da compatibilidade genética e que melhor verificação seria obtida em intervalo de quatorze dias. Utilizando este critério, não foi constatada a existência do fenômeno.

Segundo Taroda \& Gibbs (1982), a espécie Sterculia cola, é auto-incompativel apresentando interincompatibilidade entre duas plantas que estavam isoladas no campo experimental, sendo que, no final da floração elas chegaram a frutificar. Os autores alegam uma possível quebra do sistema de auto-incompatibilidade, embora a possibilidade de 
fertilização cruzada com pólen de árvores situadas à longa distância não seja descartada.

A maior parte das informações na literatura sobre a modificação genética no loco de incompatibilidade no sistema homomórfico é baseada em estudos de plantas cultivadas e, principalmente, nas hortaliças. Os melhoristas têm se empenhado em transformar clones auto-incompativeis em autocompativeis para facilitar a produção de linhagens homozigotas, contudo, não estão obtendo resultados satisfatórios, em virtude de haver, relativamente, pouca informação a respeito da variação na expressão da autoincompatibilidade em populações de muitas espécies silvestres.

Determinar o SAI é de grande importância para a compreensão da evolução do sistema reprodutivo, taxas de exogamia versus endogamia, eficiência de polinização com atenção para 0 comportamento dos polinizadores, valor adaptativo do sistema reprodutivo, fluxo gênico e tamanho de vizinhança (Dafni, 1992).

\subsubsection{Incompatibilidade genética na família Sterculiacea}

A família Sterculiaceae mostra diversidade a respeito do sistema reprodutivo, como heterostilia em Melochia (Martin, 1973) e provável incompatibilidade homomórfica em Herrania (Fryxell, 1957).

O estudo da auto-incompatibilidade em Sterculiaceae foi mais efetivo no cacaueiro (Theobroma cacao). O primeiro resultado indicando a existência do fenômeno foi publicado por Pound (1932). Fazendo cruzamentos, ele separou as plantas em autocompatíveis e auto-incompatíveis. Marshall (1933) e Voelcker $(1937,1938)$ confirmaram os resultados de Pound, trabalhando com populações de Trinidad. Cope 
(1938), trabalhando com árvores jovens estabeleceu uma variação absoluta entre auto-incompatibilidade e autocompatibilidade. Seus dados não foram sustentados por Ostendorf, (1948), que trabalhou com material de Samarang, estabelecendo divisão entre as duas classes.

Posnette (1945) testando uma população originada do Alto Amazonas introduzida em Trinidad, constatou que todas as árvores eram auto-incompativeis, porém eram compativeis com populações cultivadas na região, tendo obtido boa frutificação.

A base citológica da incompatibilidade foi estudada por Cope $(1938,1939)$. Uma comparação estatística do crescimento do tubo polínico em estigma compatível e incompatível não foi significativa. $O$ autor, também, observou que o reconhecimento da autoincompatibilidade ocorria no estigma, mas com a área de rejeição localizada no ovário.

Knight \& Rogers (1955) estudaram a incompatibilidade entre as progênies de três clones da Amazônia em experimento em dialelo, e concluíram que todas as progênies eram auto-incompatíveis, porém com um certo grau de cruzamento. Propuseram um modelo genético baseado em um loco com cinco alelos, apresentando a seguinte dominância $S 1>2=3>4>5$. O SAl é o esporofitico, com mecanismo de incompatibilidade no óvulo e pólen.

Cope (1962), utilizando material autocompatível e autoincompativel em trabalho de autopolinização e polinização cruzada mostrou que em população auto-incompatível, após terem sido autopolinizadas, a porção de óvulos que não receberam o tubo polínico foi de $25 \%, 50 \%$ e $100 \%$, conforme a reação de compatibilidade dos alelos $S$ existentes nos dois parentais e a possibilidade de se encontrarem no gameta masculino e feminino. 
O mesmo autor propôs que o gene do loco $S$ parece ter ação antes e depois da meiose de formação do grão de pólen. Portanto, o sistema de auto-incompatibilidade está sob controle gametofítico e esporofítico propondo, além disso, a existência de mais dois locos governando o sistema de incompatibilidade, denominando-os de A e B. Este alelos apresentam importância na produção de precursores não específicos para 0 alelo $\mathbf{S}$, sendo que, dessa forma, genótipos homozigotos com alelos inativos num ou mais locos $\mathbf{A}, \mathbf{B}$, e $\mathbf{S}$ serão autocompativeis.

Tendo por base a classificação de Seavey \& Bawa (1986) o cacaueiro é um planta que apresenta o sistema de autoincompatibilidade com reação no ovário pré-zigótica, ocorrendo a abscisão da flor antes da formação do embrião.

Yamada et al. (1982) estudaram a herança da compatibilidade do cacaueiro, em onze clones da família Parimari (PA), e concluíram que todos eram auto-incompatíveis. No cruzamento entre individuos deste clone auto-incompativel com clone de outra origem genética autocompatível, obteve-se segregação de $1: 1$, indicando que 0 clone PA possuía um alelo de compatibilidade.

Outras espécies da familia Sterculiaceae também apresentam o sistema de auto-incompatibilidade, como Sterculia chicha (Taroda \& Gibbs, 1982) e Cola nitida (Jacob, 1982).

Segundo Venturieri (1994), o cupuaçuzeiro é uma espécie alógama, com auto-incompatibilidade com ação tardia (no ovário), semelhante ao cacaueiro. 


\subsection{Isolamento da flor do cupuaçuzeiro}

Para o desenvolvimento da prática de polinização artificial, em trabalhos de melhoramento, é necessário evitar contaminação do material utilizado com pólen indesejável, imprescindivel na maioria das espécies, como o cacaueiro (Theobroma cacao), mandioca (Manihot esculenta), e desnecessária em outras, como em azaléia (Rhododendron prinophllum) (Padrutt et al., 1992). Por ser um fator de grande importância para o sucesso da polinização artificial, o botão floral deve ser protegido antes e/ou depois da polinização, por meio de protetor adequado à espécie.

Neves et al. (1993d), desenvolveram o protetor para botões e flores do cupuaçuzeiro, denominado de PRAMP, que é confeccionado com um copo plástico pequeno, tipo usado para tomar café, sem o fundo e coberto por um saco confeccionado com o tecido denominado de "volta espaço", com abas para a fixação em qualquer parte da planta. Este protetor superou as deficiências apresentadas pelos convencionais, confeccionados com sacos plásticos, papel, morim e o usado para proteger a flor do cacaueiro, devido a localização da flor do cupuaçuzeiro ser na extremidade dos galhos mais finos, enquanto que no cacaueiro as flores são encontradas dispostas ao longo do caule e nos galhos mais grossos.

\subsection{Polinização artificial do cupuaçuzeiro}

A polinização artificial da flor do cupuaçuzeiro, é feita de maneira direta, onde na flor do parental feminino são retirados os verticilos de proteção e realizada a emasculação, restando somente o 
pistilo. No parental masculino, retira-se a cúcula para ter acesso ao conjunto de anteras, o qual é retirado e com leves friç̧ões passado no estilete e estigma da parte feminina. É importante que seja depositado grande quantidade de pólen nos cinco estilóides, pois a polinização somente é satisfatória se houver a fertilização de quantidade de óvulos necessário para o desenvolvimento do fruto. Ao término da operação, 0 botão polinizado deve ser protegido com o protetor PRAMP, adequado para a flor do cupuaçuzeiro. A polinização pode ser realizada em botões no estádio 8 - BF3A. Após 72 horas de realização da operação, é feita a avaliação de verificação da fertilização, observando-se o aspecto do ovário. Em polinização satisfatória, o ovário apresentar-se-á com maior tamanho e róseo; caso contrário, encontrar-se-á murcho e apresentará coloração amarelada (Neves \& Silva, 1992).

Neves (dados não publicados) e Venturieri (1994), relataram que em condição natural, somente um percentual em torno de $2 \%$ das flores recebem uma quantidade de grãos pólen suficiente para promover, satisfatoriamente, o desenvolvimento do fruto. Cruden (1977), estimou a necessidade de 2 a 6 grãos de pólen compativeis, para cada óvulo. Como o cupuaçuzeiro apresenta, em torno de 48 óvulos por flor, a quantidade de pólen compativel necessária para a formação do fruto, está em torno de 96 a 288. Venturieri (1994) constatou que a flor que recebe 60 grãos de pólen compativeis apresenta $20 \%$ de probabilidade de frutificar e requer 400 grãos de pólen para que ocorra uma polinização satisfatória. 


\subsection{Sistema reprodutivo do cupuaçuzeiro}

Falcão \& Lleras (1983), constataram que flores protegidas com sacos confeccionados com o tecido filó não formavam frutos, e concluíram que na espécie não havia autofertilização espontânea. Observaram também que em condição natural somente $0,89 \%$ das flores iniciavam frutos. A produção média de frutos iniciados por planta, foi de 27,8 frutos, sendo que destes somente 17,2 frutos chegaram à maturação.

O cupuaçuzeiro apresenta alta taxa de cruzamento Neves (dados não publicados) e Venturieri (1994). Contudo, foi observado em Brasilia-DF, que uma planta isolada frutificou, possivelmente por autofertilização, sendo, portanto, uma espécie tipicamente alógama e apresentado auto-incompatibilidade com ação tardia no ovário, semelhante ao cacaueiro (Venturieri, 1994).

\subsection{Utilização da análise multivariada na avaliação da divergência genética}

A análise de divergência genética vem sendo utilizada pelos melhoristas de plantas, para investigar relações de parentesco, diversidade de origem geográfica, capacidade de combinação e heterose, entre espécies e unidades subespecíficas. A divergência genética é, geralmente, quantificada por estatísticas multivariadas, que permitem ao melhorista melhor inferência sobre os genótipos disponíveis.

A análise multivariada é o ramo da estatistica que tem por objetivo o resumo, a apresentação e a interpretação de dados 
amostrados a partir de populações em que foram avaliadas diversas variáveis.

Sneath \& Sokal (1973), lançaram os fundamentos do estudo de base numérica, onde os caracteres foram denominados de variáveis, que podem estar em escalas quantitativas ou qualitativas, e os organismos foram considerados como Unidades Taxonômicas Operacionais (OTU), o qual foi denominado de Taxonomia Numérica.

A análise multivariada é um método estatístico utilizado para estudar a relação conjunta de variáveis relacionadas, cujos dados contêm intercorrelações. A utilização desta metodologia é possível devido às diversas variáveis envolvidas serem consideradas simultaneamente, possibilitando obter interpretações que não seriam possiveis de serem obtidas com a análise de apenas um caráter individualmente (James \& Mcculloch, 1990).

Entre as técnicas estatísticas multivariadas utilizadas no estudo da divergência genética encontram-se a análise por agrupamento que, normalmente, utiliza a distância Euclideana ou a distância generalizada de Mahalanobis para a formação dos grupos, os componentes principais e as variáveis canônicas.

Para o melhorista, a escolha do método mais adequado entre as técnicas de análise multivariada, vai depender da precisão desejada, da capacidade de análise e da forma como os dados foram coletados (Cruz, 1990).

\subsubsection{Análise de agrupamento aglomerativo}

A análise de agrupamento é uma técnica multivariada que tem por finalidade reunir, por algum critério de classificação, as 
unidades amostrais (individuos, objetos, locais, etc.) em grupos, de tal forma que exista homogeneidade dentro dos grupos e heterogeneidade entre grupos (Mardia et al., 1979).

Conforme Curi (1991), o processo de formação do agrupamento envolve basicamente, cinco etapas: 1) anotação das variáveis nas unidades em classes ou como foram obtidas, as quais podem ser transformadas quando necessário; 2) escolha do coeficiente de semelhança, que pode ser: associação, usada principalmente em dados qualitativos especialmente em duplo estado; distâncias, sendo as mais usadas a Euclideana e de Mahalanobis na estruturação da matriz de dissimilaridade e correlação; 3) escolha do algoritmo de agrupamento; 4) verificação do ajuste do método, através do cálculo do coeficiente de correlação entre os elementos correspondentes da matriz inicial de dissimilaridade; e (5) a formação do dendrograma ou diagrama de árvore.

Entre os métodos de análise de agrupamento, destacam-se, os hierárquicos e de otimização, como os mais comumentes utilizados no melhoramento de plantas. Os métodos hierárquicos subdividem-se em: A) aglomerativos, como o método do vizinho mais próximo ("single linkage method"), o do vizinho mais distante ("complete linkage method"), o de ligação média ("average linkage") ponderada ou não, e divisivos, como os apresentados por Edwards \& Cavalli-Sforza (1965) e B) otimização, representado pelo método de Tocher, citado por Rao (1952).

Martinez et al. (1983) estudando vários métodos de análise multivariada concluiram que a distância Euclideana parece ser particularmente apropriada para estudos onde os caracteres medidos apresentam pequena intercorrelação, enquanto que a distância de Dempster é mais conveniente para os casos onde existe alta correlação. 
A distância Euclideana apresenta o inconveniente de ser influenciada não somente pelo número e pela escala, mas também pelas correlações não genéticas entre as variáveis em estudo, quando a mesma é estimada a partir de variáveis originais (Cruz, 1990). Contudo, estas inconveniências podem ser contornadas pela padronização dos dados e pela utilização da distância Euclideana Média, a qual é obtida dividindo-se a distância Euclideana pela raiz quadrada do número de variáveis avaliadas.

A transformação dos dados quantitativos tem por objetivo, eliminar o efeito de escalas de medidas diferentes, sendo que as mais usadas são: a divisão pelo desvio-padrão e a divisão pelo maior valor que a variável apresenta no conjunto das unidades para que assumam valor no intervalo de 0 a 1 e preserve as diferentes variabilidades (Curi, 1991).

Embora a distância Euclideana média padronizada controle os problemas inerentes ao número e escala dos caracteres avaliados, apresenta o inconveniente de não levar em consideração as correlações residuais entre os caracteres disponíveis (Cruz, 1990).

A delimitação de grupos nos dendrogramas obedece aos chamados pontos de alta mudança de nível. $O$ outro método, desenvolvido a partir de uma sugestão de Tocher, conforme Rao (1952), estabelece grupos cujas média das distâncias intragrupos, são sempre menores que as distâncias médias intergrupos.

A análise de componentes principais e/ou distância Euclideana média, têm sido muito empregadas na avaliação de acessos em bancos de germoplasma, devido ao fato de, nesta situação, ser difícil a quantificação das influências não genéticas, que atuam conjuntamente sobre os vários caracteres (Cruz \& Regazzi, 1994). 
Pereira (1989), evidencia a importância da avaliação da influência dos caracteres na discriminação genotípica em bancos de germoplasma, onde, normalmente, o número de acessos é elevado e vários descritores são utilizados.

O mesmo autor, avaliando 280 acessos de mandioca (Manihot esculenta Crantz), através da análise de componentes principais, reduziu de 28 para 14, o número de descritores morfoagronômicos utilizados na caracterização dos acessos.

Bekele et al. (1994) avaliando 53 acessos de cacaueiro (Theobroma cacao L.), utilizando os métodos dos componentes principais e método agrupamento baseado na distância Euclideana média, reduziram a lista de 62 descritores que envolviam dados quantitativos e qualitativos, para doze.

Portanto, as citações anteriores comprovam a potencialidade das técnicas multivariadas de componentes principais e métodos aglomerativos utilizando a distância Euclideana média para o estudo da divergência genética de espécies em bancos de germoplasma.

\subsubsection{Análise por variáveis canônicas}

A análise multivariada através de variáveis canônicas, foi relatada por Rao (1952). Trata-se de um processo para a avaliação do grau de similaridade entre materiais, que leva em consideração tanto a matriz de covariância residual quanto a matriz de covariância entre médias fenotípicas dos caracteres avaliados (Cruz, 1990; Cruz \& Regazzi, 1994).

Dado dois ou mais grupos de observações com mensuração em diversas variáveis, a análise discriminante deriva uma 
combinação linear das variáveis que têm maior possibilidade de correlação múltipla com os grupos. Esta correlação múltipla máxima é denominada de primeira correlação canônica. Os coeficientes de combinação linear são os coeficientes canônicos. A variável definida pela combinação linear é a primeira variável canônica ou componente canônico.

A segunda correlação canônica é obtida pela combinação linear não correlacionada com a primeira variável canônica que tem maior correlação múltipla com os grupos. $O$ processo de extração da variável canônica pode ser repetido até que o número de variáveis canônicas iguale-se ao número de variáveis originais ou ao número de classes menos um, independente de qual seja a menor classe (variáveis ou grupos).

A primeira correlação canônica é tanto maior quanto a correlação múltipla existente entre o grupo das variáveis originais. Se as variáveis originais têm baixa correlação dentro do grupo, a primeira correlação canônica não é muito maior que a correlação múltipla. Contudo, se as variáveis originais têm alta correlação dentro do grupo, a primeira correlação canônica pode ser igual a todas as correlações múltiplas.

Uma propriedade interessante das variáveis canônicas é não serem correlacionadas quando calculadas da amostra total ou de um conjunto de correlações dentro da classe. Os coeficientes canônicos não são ortogonais, portanto, as variáveis canônicas não representam direções perpendiculares no espaço formado pelas variáveis originais (SAS, 1985).

Como consequência, as variáveis canônicas podem ser utilizadas no estudo da divergência genética, quando se tem repetição 
das variáveis avaliadas em populações, variedades, acessos, linhagens, etc. (MORAIS, 1992).

Conforme Singh et al. (1981), a análise através de variáveis canônicas, permite: 1) condensar caracteres, facilitando a análise dos dados; 2) avaliar a importância de cada variável original para a variação total, possibilitando a eliminação das que pouco contribuem para a variação; e 3) efetuar o agrupamento de indivíduos com o mais alto grau de similaridade, mediante análise de dispersão gráfica no espaço bi ou tridimensional.

A avaliação da divergência genética, entre 170 variedades de arroz (Oryza sativa L.), com relação a nove caracteres agronômicos, investigada por Rao et al. (1981), mostrou que as duas primeiras variáveis canônicas encerraram cerca de $87 \%$ da variação total. Entre os caracteres com os maiores coeficientes de ponderação nos dois primeiros vetores característicos, destacaram-se o peso da panícula e 0 número de dias para $50 \%$ da floração.

Cruz (1990) quantificou a divergência genética entre cinco cultivares de milho (Zea mays L.), com relação a oito caracteres agronômicos, utilizando-se de procedimentos multivariados. $O$ autor verificou que apenas as duas primeiras variáveis canônicas seriam suficientes para explicar $97,39 \%$ da variação total disponivel.

Resende (1991) detectou divergência fenética entre as 11 espécies de orquídeas, com base em 13 caracteres avaliados, e concluiu que as duas primeiras variáveis canônicas continham $80,13 \%$ da variação total disponivel.

Oliveira (1992) estudando os padrões de variação fenotipica e ecologia de Oryzae (Poaceae) selvagens da Amazônia, utilizando 37 caracteres, em 14 populações, através de procedimentos 
multivariados de variáveis canônicas e distância de Mahalanobis, observou que as duas primeiras variáveis canônicas mantinham $79,5 \%$ da variância total, proporcionando a distinção entre 4 espécies estudadas. Amaral Júnior (1994) estudando sete caracteres morfoagronômicos em oito acessos de moranga (Curcubita maxima Duchesne), através de variáveis canônicas e método de agrupamento, fundamentado na distância generalizada de Mahalanobis, constatou que os acessos 3 (BGH 5.458) e 7 (BGH 5.642) foram os mais dissimilares, enquanto os acessos 1 (BGH 1.908) e 5 (BGH 5.618) apresentaram-se como os mais semelhantes. 


\section{MATERIAL E MÉTODOS}

\subsection{Material}

\subsubsection{Descrição da área de estudo e caracterização climática.}

O local de coleta dos dados do presente estudo, foi uma área de 1 ha, dos 30,3 ha que formam o campo experimental de fruteiras, pertencente ao Banco Ativo de Germoplasma do Centro de Pesquisa Agroflorestal da Amazônia Oriental - CPATU, localizado em Belém, a qual está situada a uma latitude de $01^{\circ} 28^{\prime} \mathrm{W}$; longitude $48^{\circ} 28^{\prime}$ $\mathrm{S}$ e a $10 \mathrm{~m}$ de altitude, no Estado do Pará, Brasil.

Segundo a classificação de Köppen, o clima é do subtipo Afi2, tropical chuvoso, caracterizado por apresentar precipitação pluviométrica média anual variando entre $2500 \mathrm{~mm}$ e $3000 \mathrm{~mm}$. O subtipo não apresenta estação seca, e a precipitação do mês menos chuvoso é igual ou superior a $60 \mathrm{~mm}$, com temperatura média anual de $25,9^{\circ} \mathrm{C}$, umidade relativa do ar $84,0 \%$, com 2219,8 horas de insolação e apresentando deficiência hídrica de $4 \mathrm{~mm}$ no mês de outubro e $15 \mathrm{~mm}$ no mês de novembro (Martorano, 1993).

O campo experimental foi implantado em 1984, com o material coletado em expedições na Amazônia brasileira, cujo objetivo era coletar germoplasma de plantas amazônicas de cultura pré-colombiana. Estas culturas eram cultivadas ou pelo menos utilizadas pelos indígenas 
antes do descobrimento da América. No caso do cupuaçuzeiro, foram coletadas plantas matrizes (propagadas vegetativamente) que apresentavam características agronômicas relacionadas à número e tamanho de fruto, acidez da polpa, ausência de doenças, etc. (Lima \& Costa, 1991).

O campo experimental foi formado por 45 clones de cupuaçuzeiro enxertados, dispostos em espaçamento de $4 \times 4 \mathrm{~m}$, com três a cinco repetições. Estes encontram-se sombreados com ingá (Inga edulis), apresentando, atualmente, altura média de, aproximadamente, 3,5 $\mathrm{m}$, e vêm sendo utilizados para observação da incidência do fungo Crinipellis perniciosa, agente causal da doença "vassoura de bruxa", tendo por objetivo selecionar os clones resistentes.

No ano de 1994 as plantas receberam $200 \mathrm{~g}$ de adubo mineral da fórmula NPK (14-28-20) e $5 \mathrm{~kg}$ de adubo orgânico (esterco de curral), sendo a adubação ministrada em partes durante o ano. Em 1995 as plantas receberam somente adubação mineral, a qual foi aplicada no mês de dezembro, no final da floração.

\subsubsection{Aspectos do material usado na coleta dos dados}

Os dados experimentais, do presente estudo, foram coletados em seis clones originados de várias partes da Amazônia brasileira (Figura 1), com três repetições, escolhidos aleatoriamente, os quais apresentaram as seguintes peculiaridades:

1 - Clone Muaná1: Foi coletado na Fazenda Santo André, "Ilha do Livramento", no municipio de Muaná, Estado do Pará, por apresentar 


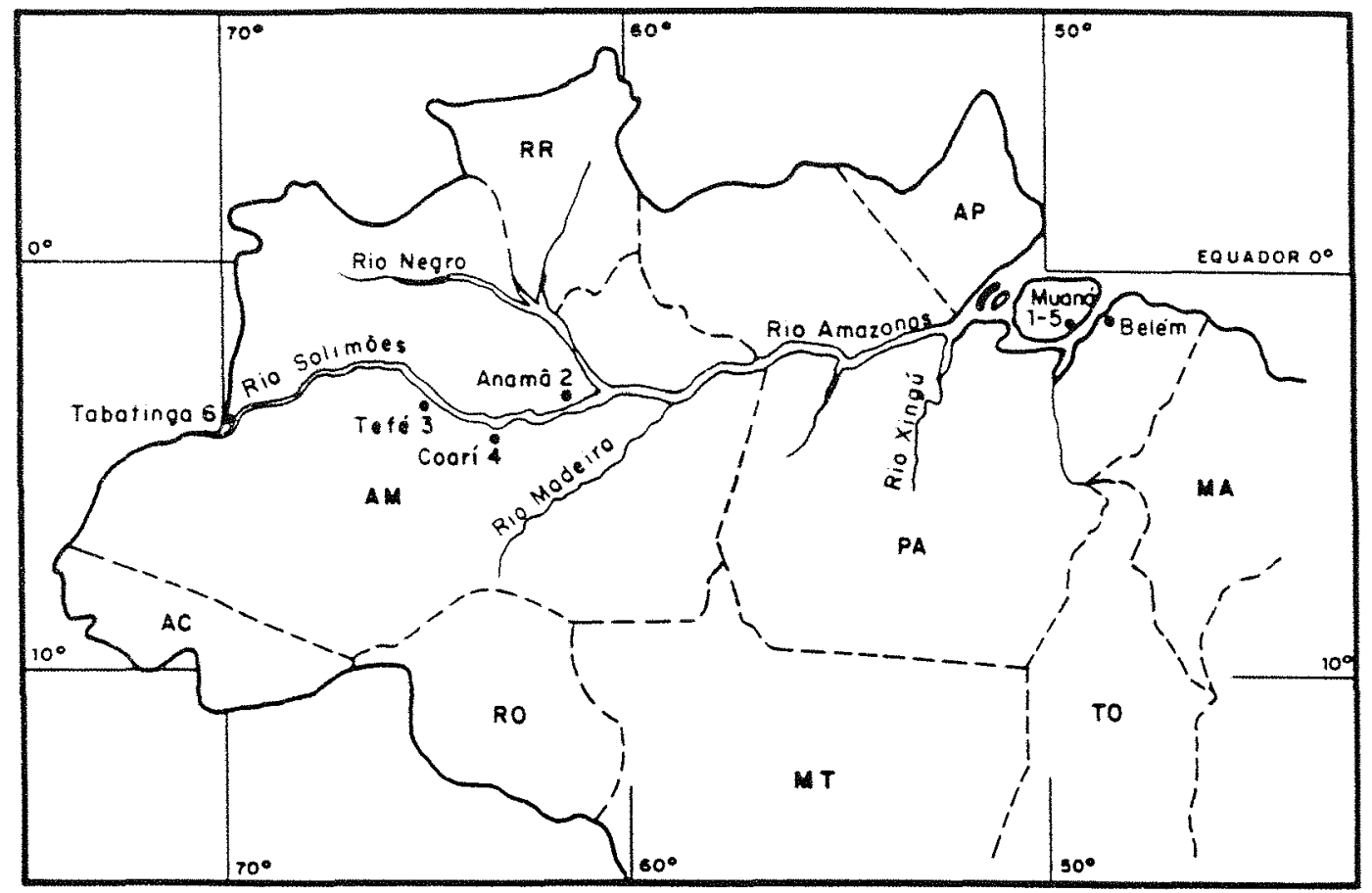

1: Muaná1-PA

2: Anamã-AM

3: Tefé-AM

4: Coarí-AM

5: Muaná2-PA

6: Tabatinga-AM

Figura 1: Mapa de localização geográfica das regiōes de origem dos seis clones e local de coleta dos dados do presente trabalho. 
polpa com pouca acidez e coloração amarelada e a árvore não apresentar sintomas da doença "vassoura de bruxa".

2 - Clone Anamã: Foi coletado na residência do Sr. Eustáquio Viana dos Santos, no município de Anamã, às margens do rio Solimões, Estado do Amazonas, por apresentar o fruto com as cinco lojas bem definidas, proporcionando o aspecto de quina, e devido a essa característica, recebeu a denominação de "cupuaçu de quina".

3 - Clone Tefé. Foi coletado na localidade de Piraruaia, no sítio do Sr. Cícero Domingos, no município de Tefé, às margens do rio Tefé, Estado do Amazonas, por apresentar boa frutificação, não apresentar sintomas da doença "vassoura de bruxa" e fruto com diâmetro grande.

4 - Clone Coari: Foi coletado na Comunidade Espirito Santo, no município de Coari, às margens do rio Solimões, Estado do Amazonas, por apresentar fruto de tamanho grande.

5 - Clone Muaná2: Foi coletado na Fazenda Santo André, "Ilha do Livramento", no município de Muaná, Estado do Pará, por apresentar polpa com pouca acidez e coloração amarelada e a árvore não apresentar sintomas da doença "vassoura de bruxa".

6 - Clone Tabatinga: Foi coletado na estrada vicinal Norte-2, no lote do Sr. Francisco Paulo, no município de Tabatinga, às margens do rio Solimões, Estado do Amazonas, por ser considerado precoce e não apresentar sintomas da doença "vassoura de bruxa". 


\subsection{Métodos}

\subsubsection{Fenologia da floração e frutificação}

Durante os anos de 1994 e 1995, foram realizados acompanhamentos das características fenológicas de floração e frutificação, nas três repetições, dos seis clones, sendo que, semanalmente, eram coletados e contados, todos os botões e flores caídos embaixo da planta; mensalmente os frutos imaturos $\mathrm{e}$, diariamente, os frutos que amadureciam durante o periodo da floração e frutificação.

Os resultados permitiram observar 0 início, pico e término da floração, período da floração, duração da frutificação, proporção de gemas florais emitidas em relação às flores abertas, frutos com desenvolvimento inicial e frutos maduros, assim como a proporção flor:fruto maduro.

Os dados fenológicos foram correlacionados com os dados da precipitação pluviométrica, obtidos na Estação Meteorológica do CPATU, a qual encontra-se localizada a $15 \mathrm{~km}$ do local de onde o experimento está instalado.

Os dados referentes ao rendimento, como comprimento, diâmetro e peso do fruto, número e peso de sementes, peso e espessura de casca e peso de polpa, foram também coletados para serem usados na análise de divergência genética.

Para observar todos os eventos, acima citados, foram elaboradas planilhas de campo.

Os resultados do acompanhamento fenológico realizado no ano de 1994, serviram como referencial para a aplicação dos 
tratamentos de determinação do sistema reprodutivo, ao longo da floração, no ano de 1995.

\subsubsection{Caracterização floral}

Foram coletados dados de biologia floral, que caracterizam a flor, os quais foram utilizados como variáveis na análise de divergência genética e determinação indireta do sistema reprodutivo, como:

- Cor da flor: foi observado a coloração das lâminas das pétalas, através do contraste visual, com o auxílio de uma carta de cores;

- Estimativa da quantidade de grãos de pólen da flor: foi realizada a contagem direta de todos os grãos de pólen de uma teca da antera biteca central, em seis botões florais no estádio 4 - BF $\geqslant 12 \mathrm{~mm}$ (botão fechado igual ou maior que $12 \mathrm{~mm}$ de diâmetro) (Figura $2 \mathrm{~A}$ ) e extrapolado para o conjunto de estame e flor.

A teca da antera central foi removida para uma lâmina com uma gota do corante carmim acético a $2 \%$ e macerada até não haver parte grande da parede da antera. Após três minutos a lâmina foi observada ao microscópio e com auxilio de lente de aumento de $200 x$, foi realizada a contagem direta dos grãos de pólen, movimentando-se, lateralmente, o campo do foco do microscópio até cobrir por completo a lâmina. Foi calculado um índice de perdas em decorrência do esmagamento da antera calculado em $3 \%$, o qual foi adicionado como um fator de correção em todas as amostras examinadas.

- Viabilidade dos grãos de pólen: foi realizado através do método indireto com o corante carmim acético a $2 \%$, em 500 grãos de 


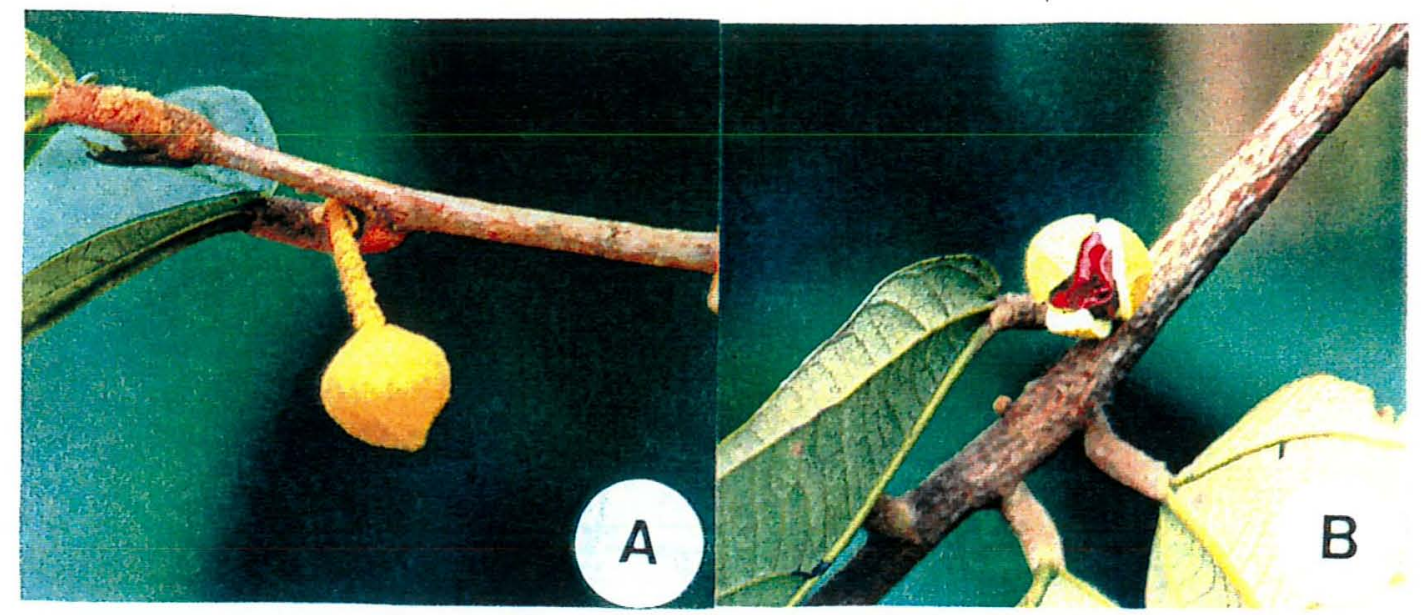

Figura 2: Botão floral do cupuaçuzeiro. A: estádio $4-\mathrm{BF} \geqslant 12 \mathrm{~mm}$ (botão fechado igual ou maior que 12 milímetros de diâmetro) e B: estádio 8 - BF3A (botão fechado com três aberturas no cálice).

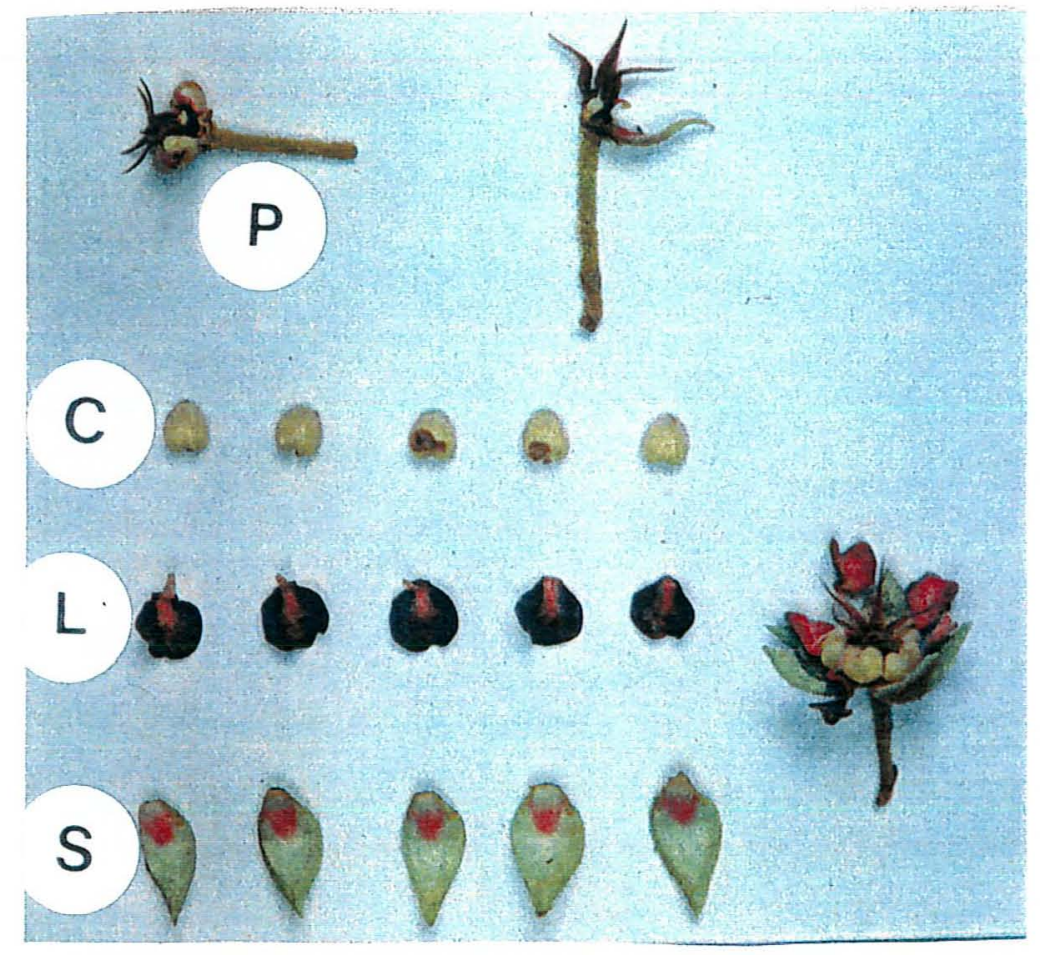

Figura 3: Flor do cupuaçuzeiro em vista lateral e as diversas partes que a compõem. S: sépala; L: lâmina da pétala; C: cúcula; e P: pedúnculo. 
pólen por clone, coletados em seis botões no estádio 8 - BF3A, usado nas polinizações artificiais (Figura 2 B).

- Contagem de óvulo: foi realizada, conforme a metodologia desenvolvida por Pound (1931) para a flor do cacaueiro, a qual consiste em remover a parede do ovário, com uma agulha fina e, com auxílio de uma lupa, promover a contagem direta dos óvulos, individualmente, dentro de cada lóculo do ovário. A contagem foi realizada em seis botões, no estádio 8 - BF3A, em cada clone.

- Tamanho da flor: em seis flores de cada clone, foram medidos o comprimento e diâmetro do pedúnculo e cúcula, comprimento e largura das sépalas e lâminas das pétalas e distância entre o estigma e as anteras (Figura 3).

\subsubsection{Determinação direta do sistema reprodutivo}

Para a determinação direta do sistema reprodutivo, foram executados cinco tratamentos, empregando-se metodologia adaptada a partir do modelo proposto por Dafni (1992), sendo que o tratamento para a observação da polinização aberta foi realizado em todos os clones nos anos de 1994 e 1995. Os demais tratamentos foram aplicados em todos os clones, exceto ao clone Tefé no ano de 1994 e Tabatinga em 1995.

Tratamento 1: Polinização aberta - (PAB)

Objetivo: Estimar o percentual de frutificação desenvolvido em condições naturais. 
Para análise da polinização aberta, foram realizados acompanhamentos da fenologia de floração e frutificação nos seis clones, durante o período da floração nos dois anos.

\section{Tratamento 2: Agamospermia - (AGA)}

Objetivo: Verificação da agamospermia (produção de sementes sem fertilização).

Foram marcados, emasculados e retirados os verticilos de proteção de 15 e 20 botões florais no estádio 8 - BF3A, em cada clone, nos anos de 1994 e 1995, respectivamente. Após a operação, os botões foram protegidos, com 0 protetor PRAMP, para evitar polinizações indesejáveis. A primeira avaliação de verificação do início da formação do fruto, foi realizada 72 horas após a aplicação do tratamento. A operação de "limpeza" foi realizada com auxílio de bisturi e pinça.

Tratamento 3: Autopolinização espontânea - (APE)

Objetivo: Observação da autopolinização natural.

Foram identificados e protegidos 15 e 20 botões florais no estádio 8 - BF3A, em cada clone, nos anos de 1994 e 1995, respectivamente. Para a proteção foi utilizado o PRAMP e a primeira avaliação para a verificação do início da formação do fruto, foi realizada 72 horas após a operação.

Tratamento 4: Autopolinização forçada (Gueitonogamia) - (APF)

Objetivo: Observar o comportamento da flor polinizada com o seu próprio pólen, ou seja, sem haver troca de genes.

As polinizações foram realizadas em 15 botões florais no estádio 8 - BF3A no ano de 1994 e em 15 a 20 botões florais no ano de 
1995, no mesmo estádio, em cada clone. Foi utilizada a metodologia usada por Neves \& Silva (1992). A primeira avaliação para a verificação do início da formação do fruto foi realizada 72 horas após a operação e a segunda aos 12 dias, período no qual o fruto iniciado muda da coloração rósea para marrom, cor do fruto maduro (Neves et al., 1993b).

O tratamento foi realizado no horáio de $16 \mathrm{~h}$ às $18 \mathrm{~h}$, em virtude de ser o período de maior intensidade de abertura das flores (Neves et al., 1992c) e o período de maior receptibilidade do estigma e estilete (Silva et al., 1993b). Em todas as polinizações foi tomada a precaução de depositar grande quantidade de pólen no estigma e estilete. Os grãos de pólen usados nas polinizações foram obtidos a partir de botões florais no estádio 8 - BF3A, estádio em que estes apresentavamse viáveis e férteis (Neves et al., 1993b), e não havia a possibilidade de terem sidos contaminados por pólen de outras plantas.

Após a operação de polinização artificial, o botão floral foi protegido com o PRAMP, para que não houvesse a possibilidade de contaminação com grãos de pólen indesejáveis.

\section{Tratamento 5: Polinização cruzada (Xenogamia) - (PCR)}

Objetivo: Observar o comportamento da flor sob a ação de pólen de outras plantas, ou seja, avaliar a capacidade de troca gênica.

Este experimento foi realizado utilizando-se o delineamento de dialelo completo com reciprocos, de forma que todos os clones foram intercruzados.

As polinizações foram realizadas em 15 botões florais no estádio 8 - BF3A no ano de 1994 e em 15 a 20 botões florais no ano de 1995, no mesmo estádio, em cada clone. Foi utilizada a metodologia usada por Neves \& Silva (1992). A primeira avaliação para a verificação 
do inicio da formação do fruto foi realizada 72 horas após a operação e a segunda aos 12 dias.

Após a operação de polinização o botão floral foi protegido com o PRAMP, para que não houvesse a possibilidade de contaminação com grãos de pólen indesejáveis.

Todos os cuidados tomados no tratamento anterior, também foram adotados neste.

No ano de 1994, os tratamentos foram executados no início do florescimento, para observar o completo desenvolvimento dos frutos originados a partir de polinização artificial.

No ano de 1995, os tratamentos foram executados no início da floração. Porém, em plantas que estavam com número muito grande de frutos, estes foram derrubados com idade de quinze dias, para não sobrecarregarem e influenciarem na formação de frutos de meio e final da floração.

Para avaliar compatibilidade dos clones, foi utilizado o índice de auto-incompatibilidade $(|\mathrm{A}|)$, sugerido por Zapata \& Arroyo (1978).

$|A|=\quad$ Frutificação de autopolinização

Frutificação de polinização cruzada

Os valores obtidos para o $|A|$, são classificados em:

$>1=$ Auto-incompatível

$>0,2<1=$ Parcialmente auto-incompativel

$<0,2=$ Principalmente auto-incompativel

$0=$ Completamente auto-incompatível 
As taxas de frutificação após a autopolinização artificial são classificadas em:
Auto-incompativel:
0 a $3 \%$ Classe 0
Ligeiramente Autocompativel: 3 a $30 \%$ Classe 1
Altamente Autocompativel: $\quad>30 \%$ Classe 2 .

\subsubsection{Determinação indireta do sistema reprodutivo}

\subsubsection{Relação entre morfologia, viabilidade floral e o sistema reprodutivo.}

Cruden (1977), constatou que o nivel de cruzamento de uma espécie mostra forte associação com a dimensão floral, separação temporal da deiscência da antera e receptibilidade do estigma e a relação espacial do estigma e antera. Em decorrência disso, propôs um índice de cruzamento (IC), que é expressado pela somatória dos valores atribuídos às seguintes características:

1 - Diâmetro da flor (ou inflorescência)

$$
\begin{gathered}
<1 \mathrm{~mm}=0 \\
1 \text { a } 2 \mathrm{~mm}=1 \\
2 \text { a } 6 \mathrm{~mm}=2 \\
>6 \mathrm{~mm}=3
\end{gathered}
$$

2 - Separação temporal da deiscência da antera e receptibilidade do estigma.

Homogamia, protogenia $=0$

Protandria $\quad=1$ 
3 - Posição espacial do estigma e antera.

$\begin{array}{ll}\text { Mesmo nivel } & =0 \\ \text { Espacialmente separado } & =1\end{array}$

Os resultados encontrados para O IC são classificados, como:

$$
\begin{aligned}
& 0=\text { Cleistogamia } \\
& 1=\text { Autogamia obrigatória } \\
& 2=\text { Autogamia facultativa } \\
& 3=\text { Autocompativel, alguma demanda de polinizadores } \\
& 4=\text { Polinização cruzada, parcialmente auto- }
\end{aligned}
$$
incompativel, demanda por polinizadores.

\subsubsection{Proporção pólen:óvulo (P:O)}

A mudança evolucionária que transformou as plantas alógamas (predominantemente de fertilização cruzada) para autógamas (predominantemente de autofertilização) proporcionou um decréscimo no tamanho da flor e alteração na morfologia da flor (Ornduff, 1969) causando uma redução no custo de energia por flor. A diminuição no número de grãos de pólen não foi acompanhada pelo decréscimo no número de óvulos, causando a diminuição na proporção pólen:óvulo desde cleistogamia, autogamia a alogamia. Com base nessas informações Cruden (1977) propôs um método de observação indireta do sistema reprodutivo no qual correlaciona o número de grãos de pólen com o número de óvulos produzidos por uma flor ou inflorescência. 
Com base na proporção P:O observada num grande número de espécies, montou a seguinte classificação:

Cleistogamia

Autogamia obrigatória:

Autogamia facultativa:

Xenogamia facultativa

Xenogamia obrigatória
P:0

$P: 0$

P:0

$P: 0$

$P: 0$
$2,7-5,4$

$18,1-39,0$

$31,9-396,0$

$244,7-2588,0$

$2108,4-195525,0$

\subsubsection{Determinação da divergência genética pela utilização de} análise multivariada.

A análise de divergência genética foi utilizada com o objetivo de detectar a similaridade genética entre os clones, a qual foi correlacionada com os dados oriundos das polinizações controladas, além disso procurou-se distinguir as variáveis que apresentavam maior valor discriminatório para a classificação dos clones analisados, utilizando a técnica de agrupamento com o algoritmo de ligação média não ponderada (UPGMA) e método de otimização sugerido por Tocher, tendo por base, a matriz de dissimilaridade entre os clones quantificada pela distância generalizada de Mahalanobis, denominada $D^{2}$ ii' e dispersão dos escores em gráfico, cujos eixos foram representados pelas duas primeiras variáveis canônicas. 


\subsubsection{Análise de Agrupamento}

\subsection{Método de agrupamento utilizando o algoritmo de ligação média não ponderada (UPGMA).}

Esta è uma técnica conglomerativa hierárquica, desenvolvida por Sokal \& Michener (1958), cujo procedimento consiste, inicialmente, na identificação, na matriz de dissimilaridade genética, dos clones mais similares, os quais constituirão o primeiro grupo. O processo de identificação dos clones mais similares é repetido sobre a nova matriz de dissimilaridade genética, por meio da determinação da distância média entre o grupo e os demais clones, até que sejam reunidos em um único grupo.

A distância entre o grupo $\mathrm{k}$ e l é definida por:

$D_{k l}=\sum_{i \varepsilon l} d\left(X_{i}, X_{j}\right) /\left(N_{k} N_{l}\right)$

$D_{k l}=$ Qualquer distância ou dissimilaridade medida entre os grupos $\mathrm{k}$ el.

$k$ o grupo resultante do subconjunto de $(1,2, \ldots \ldots, n)$

I o grupo resultante do subconjunto de $(1,2, \ldots, n)$

$d\left(X_{i}, \quad X_{j}\right)$ qualquer distância ou similaridade medida entre observações ou vetores $x \in y$.

$N_{k}$ números de observações no grupo $k$;

$N_{1}$ número de observações no grupo $\mathrm{I}$; 


$$
\begin{aligned}
& \text { Se } d(x, j)=\|x-y\| \text { então } \\
& D_{k l}=\|x-y\|+W_{k} / N_{k}+W_{1} / N_{l}
\end{aligned}
$$

$$
\begin{aligned}
& W_{k}=\sum_{\text {isk }}\|x-y\|^{2} \\
& N_{k}=\sum_{\text {i } \varepsilon}\|x-y\|^{2}
\end{aligned}
$$

A fórmula combinatorial é

$$
D_{j m}=\left(N_{k} D_{j k}+N_{j} D_{j l}\right) / N_{m}
$$

$\mathrm{Na}$ fórmula combinatorial, assume-se que o grupo $\mathrm{k}$ e I são unidos para formar o grupo $\mathrm{m}$ e a fórmula dá a distância entre o novo grupo $m$ e qualquer outro grupo $\mathbf{j}$.

A ligação média da distância entre dois grupos é a distância média entre pares de observações, em cada grupo. A ligação média direciona a junção dos grupos com pequena variância e é amplamente voltada para produzir grupos com a mesma variância (SAS, 1985).

\subsection{Método de agrupamento pelo método de otimização do} Tocher.

Este método é estabelecido pelo critério em que a distância média intragrupo é inferior a qualquer distância intergrupo (Singh \& Chaudhary, 1979). 
O desenvolvimento do método exige, inicialmente, a formação do primeiro grupo, o qual é constituído pelo par de clones que apresentar o menor valor de distância ( $D^{2}$ ii' ) na matriz de dissimilaridade entre os clones. A partir desta etapa, avalia-se a possibilidade de inclusão de outros clones no primeiro grupo, respeitando-se 0 critério anteriormente. Para tanto, procede-se à comparação entre 0 acréscimo no valor da distância média intragrupo, e o valor máximo de $D^{2}{ }_{i i}$, denominado $\alpha$, que corresponde ao maior elemento do conjunto de menores distâncias, em relação aos clones (Cruz \& Regazzi, 1994; Morais, 1992). A inclusão de um clone em um grupo é possivel quando:

$$
\frac{D^{2}(i j) k}{n}<\alpha \text {, onde }
$$

$D^{2}(i j) k$ é a distância entre o grupo ij e o acesso $k$, obtida pela expressão:

$$
D^{2}(i j) k=D^{2} i k+D^{2} j k \text {, onde }
$$

$D^{2}$ ik é a distância entre os clones i e $\mathbf{k}$;

$D^{2} \mathrm{jk} \quad$ é a distância entre os clones j j $\mathbf{k}$; e

$\mathrm{n} \quad$ é o número de clones que constitui o grupo original.

\subsubsection{Material utilizado na análise da divergência genética}

Para a determinação da divergência genética foram coletados dados em todos os clones, exceto ao clone Tabatinga.

$\mathrm{Na}$ análise multivariada foram utilizados onze caracteres de morfologia floral, mensurados em milimetros $(\mathrm{mm})$ e 
contagem, obtidos a partir de seis flores em cada clone, e oito caracteres do fruto mensurados em gramas $(\mathrm{g})$ e centimetros $(\mathrm{cm})$ em seis frutos produzidos no ano de 1994 e 1995, considerados a seguir:

1 - comprimento da sépala (CS)

2 - largura da sépala (LS)

3 - comprimento da lâmina da pétala $(\mathrm{CL})$

4 - largura da lâmina da pétala (LL)

5 - comprimento da cúcula (CC)

6 - largura da cúcula (LC)

7 - comprimento do pedúnculo (CP)

8 - diâmetro do pedúnculo (DP)

9 - distância do estigma-estilete a antera (DEE-A)

10 - número de óvulos (NO)

11 - número de grãos de pólen por flor (NP)

12 - número de sementes (NS)

13 - peso de sementes (PS)

14 - peso da casca (PC)

15 - peso da polpa (PP)

16 - peso do fruto (PF)

17 - espessura da casca (EC)

18 - comprimento do fruto (CF)

19 - diâmetro do fruto (DF)

\subsubsection{Operacionalização das análises}

Para atender às condições exigidas pela análise estatistica, os dados referentes à emissão de gemas florais no ano de 
1995 foram transformados pela fórmula $Z(y)=y^{(1-b / 2)}$, cujo $b$ calculado com base na homocedasticidade dos dados e transformação estabilizadora da variância, foi 1,663937.

Todas as análises estatisticas foram realizadas através do Systems Analysis Statistics (SAS) na versão 5.0. Para a análise de estatística simples, como análise da variância com aplicação do teste " $F$ " foi utilizado as Procedure ANOVA e para o teste "T" foi utilizado a Procedure TTEST. Os graus de liberdade (G.L.) ligado ao teste "T" foi calculado com base na fórmula de Sattertwaite. A análise multivariada de variáveis canônicas foi realizada através da Procedure CANDISC, e o método de agrupamento através da Procedure CLUSTER. 


\section{RESULTADOS E DISCUSSÃO}

\subsection{Fenologia da floração e frutificação}

No ano de 1994 a floração do cupuaçuzeiro começou com a emissão das primeiras gemas floriferas, na primeira quinzena de março e terminou na primeira quinzena de novembro, sendo que o período médio de florescimento dos clones foi de 11,7 quinzenas, com variação de 8 quinzenas (clone Muaná2) a 15,6 quinzenas (clone Coarí). O ponto máximo da floração ocorreu na segunda quinzena de agosto (Figura 4).

No ano de 1995 a floração iniciou-se somente na segunda quinzena de maio, portanto seis quinzenas depois do início em 1994. O final da floração foi na segunda quinzena de novembro, dessa forma o período médio de florescimento dos clones foi de 10,67 quinzenas, com variação de 9 quinzenas (clone Muaná2) a 12 quinzenas (clone Coarí). O ponto máximo de floração foi na segunda quinzena de julho, portanto um mês antes do ocorrido no ano de 1994 (Figura 5).

Portanto, foi observado deslocamento da floração no ano de 1995 em relação a 1994, sendo que esta mudança não pode ser atribuída à precipitação pluviométrica, pois não houve diferença significativa na quantidade de chuva entre os dois primeiros semestres dos anos $(T=0,23 ; G . L .=22 ; P>0,05)$. No entanto, no primeiro semestre de 1994, as chuvas foram distribuídas mais uniformemente, enquanto que 


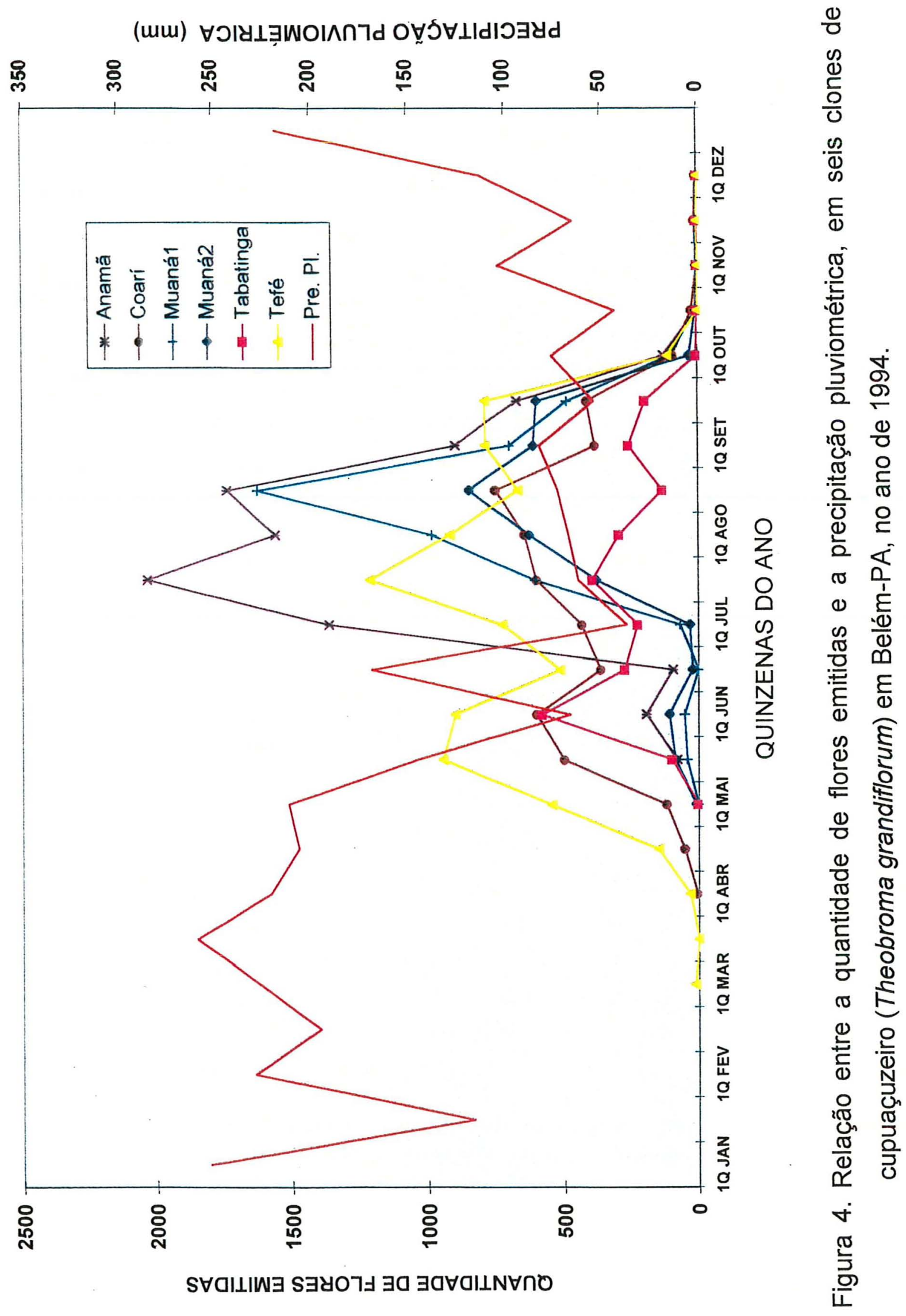




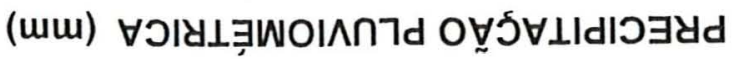

율

이 유 유

옹ํㅁ

$\stackrel{\circ}{\circ}$

요

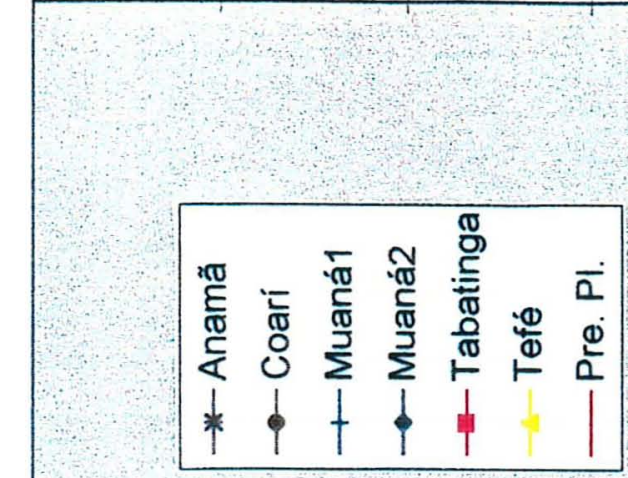

0

은
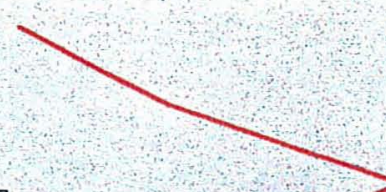

岃

$\frac{.0}{\Phi}$

$\frac{\mathrm{L}}{\mathrm{Q}}$

ญే

$x^{2} \stackrel{3}{2}$

3
2
0
5
5
0
0

เค

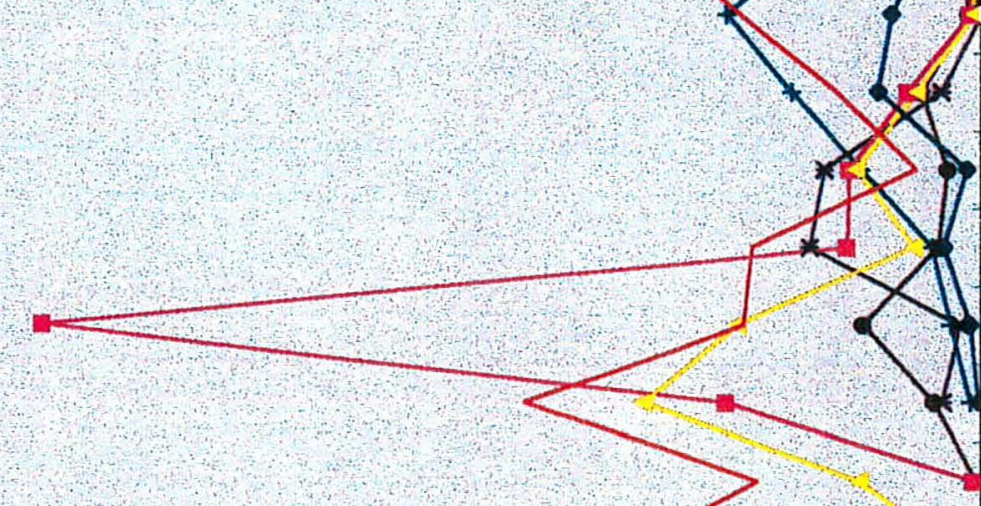

$\underline{-1}$

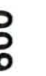

:

:

ㅎำ

윰ำ

용

S

두

음 
no primeiro semestre de 1995, ocorreram grandes oscilações (Figura 6), o que pode ter influenciado no deslocamento da floração.

O florescimento do cupuaçuzeiro ocorreu em picos, os quais variaram de dois em 1994 a três em 1995 (Figuras 4 e 5). Este modelo de floração é característico das espécies tropicais de floresta não sazonal, concordando com os resultados encontrados por Opler et al. (1980) que estudaram árvores e arbustos da floresta úmida na Costa Rica, estando pois, fortemente correlacionado com as características climáticas da região.

Foi constatada correlação negativa entre o modelo de floração e a precipitação pluviométrica da região, pois o maior pico de emissão de gemas florais, correspondeu ao período de menor precipitação (Figura 6), corroborando o observado por Calzavara et al. (1984), Neves et al. (1993a) e Venturieri (1994).

A floração no periodo seco e a frutificação no período chuvoso, maximiza a competitividade pela atração dos polinizadores e umidade para a atividade fisiológica de desenvolvimento dos frutos, caracterizando, dessa forma, a interação entre a espécie e o ambiente, demonstrando a adaptação da espécie às condições ambientais do trópico úmido.

A floração na estação seca, onde ocorre maior luminosidade diária e menor umidade no ar, apresenta muitas vantagens, como: favorecimento do desempenho dos polinizadores, possibilitando que estes permaneçam mais tempo no campo polinizando; concentração do néctar (qualidade do ponto de vista nutricional do polinizador), facilita 0 transporte de néctar; aumenta a viabilidade do pólen de espécies sensiveis à umidade (Janzen, 1967) e maximiza a polinização pela não retirada dos grãos de pólen antes de iniciar o processo de fecundação. 


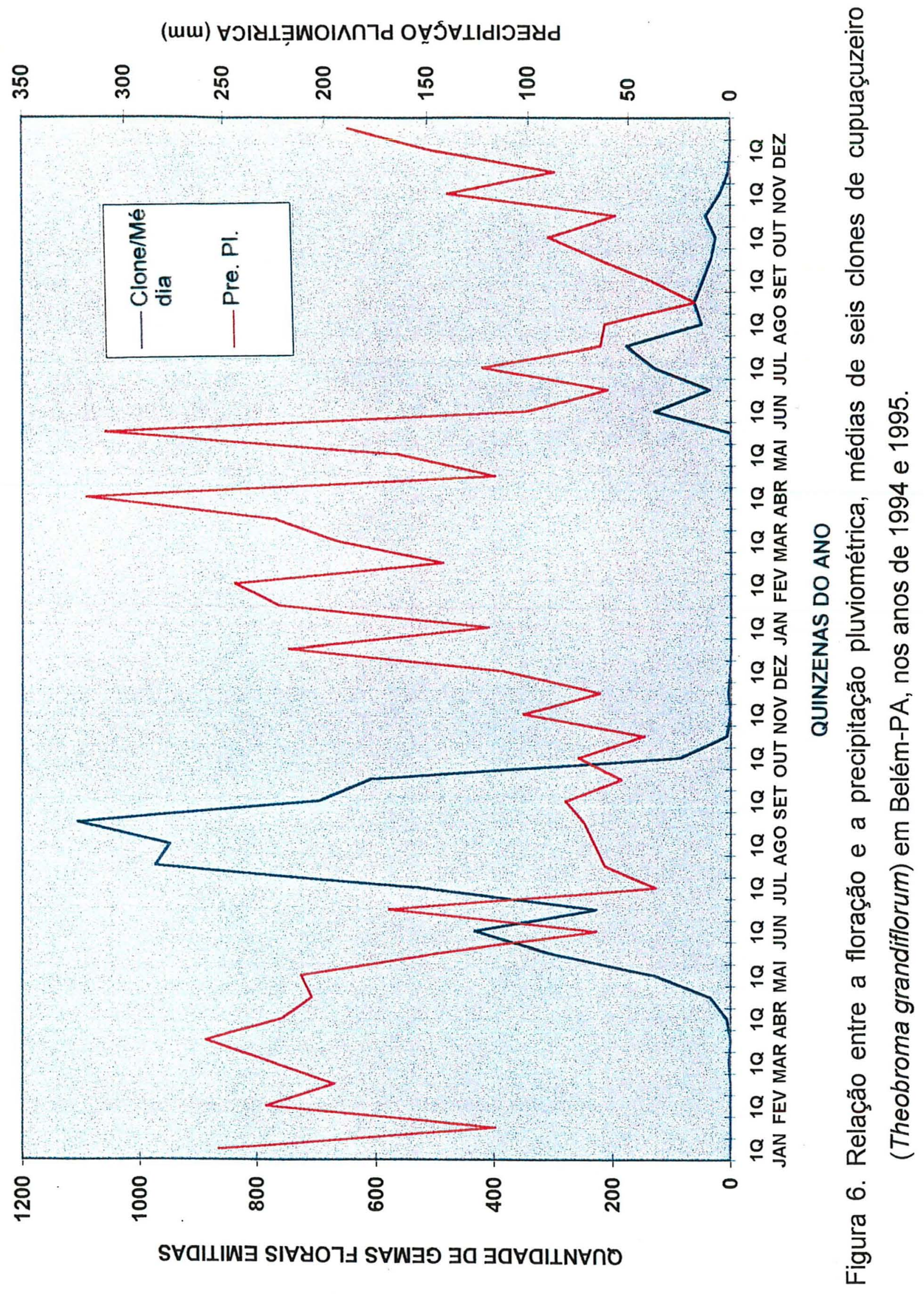


O florescimento no periodo mais seco do ano não é uma caracteristica seguida por todas as espécies que compõem a floresta tropical Amazônica, pois Jardim (1991) constatou que o açaizeiro (Euterpe oleracea) apresenta o pico máximo de floração nos meses de janeiro a maio, período mais chuvoso, enquanto que o ponto alto da frutificação ocorre de junho a dezembro, periodo rnais seco, completamente oposto ao que foi encontrado para o cupuaçuzeiro no presente trabalho.

A floração apresentou diferença altamente significativa ( $T=4,64 ; G . L .=5,3 ; P<0,01)$ na emissão de gemas florais entre os dois anos. A floração em 1995 foi em média 85,11\% menor do que a de 1994 (Figura 6), contudo o percentual de redução foi diferenciado entre os clones, variando de 47,37\% (clone Tabatinga) a 97,27\% (Clone Anamã).

Autores como Agren (1988), Campbell (1989) e Vaugton (1991), já observaram que entre anos há variação na frutificação e propuseram modelos teóricos para prognosticar ótimas condições de frutificação em plantas hermafroditas sob diferentes condiçōes.

No ano de 1995 as plantas receberam uma quantidade bem menor de adubação, porém isso não é justificativa para a reduzida emissão de gemas florais. Em 1994, por ocasião da escolha das plantas para a realização deste trabalho, entre as cinco plantas que compõem os clones sorteados, somente três foram utilizadas, aquelas que apresentavam maior floração, justamente para facilitar os trabalhos de polinização controlada. Porém, as plantas que não foram selecionadas em 1994, foram as que mais floriram e frutificaram em 1995, fato constatado nos clones Tabatinga e Anamã, eliminando, dessa forma, o fator adubação como o maior responsável pela grande oscilação na emissão de gemas florais no período estudado. 
Esta constatação não significa que o fator nutricional não influência na produção. Pelo contrário, o nivel de frutificação apresentou variação altamente significativa $(T=3,69 ; \mathrm{G} . \mathrm{L} .=10 ; \mathrm{P}<$ $0,01 \%)$. As plantas melhores nutridas em 1994 produziram em média 10,15 frutos maduros, contra 4,44 no ano de 1995, indicando, portanto, que a condição nutricional não é o único fator controlando a produção do cupuaçuzeiro.

A constatação da grande oscilação entre os anos, mostrada pelos clones, sugere seleção para clones com produção mais estável ou então a estratégia, em plantios comerciais, de se combinarem materiais que apresentem boa produção em anos diferentes, visando manter a produção estabilizada. A utilização de clones com o mesmo comportamento proporcionará boa produção em um ano, porém baixa em outros.

O padrão de floração diferenciado apresentado pelo clone oriundo de Tefé, com antecipação da floração (Figuras 4 e 5) é um fator de grande interesse econômico pois promove a produção de frutos no início da safra, quando o produto recebe melhor preço no mercado. Porém para que isso ocorra é necessário encontrar outros clones com estas mesmas características e que sejam geneticamente compativeis, para possibilitar polinização efetiva.

Mais importante do que a quantidade de gemas florais produzidas é a relação entre o número de gemas florais e flor, pois isto indica maior probabilidade de produção de frutos, em virtude da maior atração de polinizadores.

Como o cupuaçuzeiro apresenta várias pragas que provocam danos ao botão floral, clones com melhor relação gema floral:flor podem ser que sejam mais tolerantes ao ataque desses insetos. 
A quantidade de gemas florais emitidas pelos clones apresentou diferença significativa ao nivel de $5 \%$ de probabilidade pelo teste de Tukey, nos anos de 1994 e 1995 (Tabelas 1 e 2).

Os clones apresentaram grande variação na emissão de gemas florais no ano de 1995, sendo que na análise da variância com os dados brutos obteve-se coeficiente de variação (C.V.) de $72,90 \%$, e não foi detectado diferença estatística significativa entre eles pelo teste de Tukey a 5\%. Porém, na análise da variância com os dados transformados, obteve-se C.V. $13,20 \%$ e foi detectada diferença estatística na floração dos clones.

O clone Tabatinga, no ano de 1994 foi o que apresentou menor floração, porém em 1995 inverteu sua posição, passando a ser o clone com maior emissão de gemas florais. Situação inversa ocorreu com o comportamento da floração do clone Anamã, que em 1994 foi o clone com maior floração, porém em 1995 foi o penúltimo, entre os seis clones estudados.

Uma caracteristica interessante é que em populações propagadas pelo homem, mesmo sem nenhum manejo posterior, também ocorreu oscilação na produção de frutos, no mesmo período, indicando a possível bianualidade da espécie. É como se as plantas utilizassem um ano para "descansar", preparando-se para uma nova frutificação no ano seguinte, característica esta de planta perene com ciclo de vida longo (espécie $\mathrm{K}$ ), em que não é necessário reproduzir todos os anos para a manutenção da espécie. Os acompanhamentos fenológicos dos próximos cinco anos mostrarão a existência ou não do fenômeno.

Conforme já constatado por Neves et al. (1993a) as plantas com grande produção, no final do período de frutificação 
Tabela 1: Potencial de florescimento. Os valores são percentuais baseados em três repetições por clone, que foram derrubados na fase de botão, flor, fruto imaturo, fruto maduro e total de gemas florais emitidas em seis clones de cupuaçuzeiro (Theobroma grandiflorum) em Belém-PA, no ano de 1994.

\begin{tabular}{|c|c|c|c|c|c|}
\hline Clone & $\begin{array}{c}\text { Gema } \\
\text { floral emitida }\end{array}$ & $\begin{array}{c}\text { Botão } \\
(\%)\end{array}$ & $\begin{array}{l}\text { Flor } \\
(\%)\end{array}$ & $\begin{array}{c}\text { Fruto } \\
\text { imaturo } \\
(\%)\end{array}$ & $\begin{array}{l}\text { Fruto } \\
\text { maduro } \\
(\%)\end{array}$ \\
\hline Anamã & $10141,00 a^{*}$ & 13,27 & 86,40 & 0,27 & 0,06 \\
\hline Tefé & 8936,33 a b & 6,64 & 93,02 & 0,22 & 0,12 \\
\hline Coari & $5264,00 \mathrm{a} b \mathrm{c}$ & 7,13 & 92,31 & 0,39 & 0,17 \\
\hline Muaná1 & 5240,33 a b c & 8,38 & 89,48 & 1,85 & 0,29 \\
\hline Muaná2 & 4347,67 b c & 20,77 & 77,38 & 1,65 & 0,20 \\
\hline Tabatinga & $2669,33 \quad \mathrm{C}$ & 6,37 & 91,80 & 1,40 & 0,48 \\
\hline $\begin{array}{c}\text { Média } \\
\text { C.V. }(\%)\end{array}$ & $\begin{array}{c}6099,78 \\
34,09\end{array}$ & 10,46 & 88,63 & 0,75 & 0,17 \\
\hline
\end{tabular}

Tabela 2: Potencial de florescimento. Os valores são percentuais baseados em três repetições por clone, que foram derrubados na fase de botão, flor, fruto imaturo, fruto maduro e total de gemas florais emitidas em seis clones de cupuaçuzeiro (Theobroma grandiflorum) em Belém-PA, no ano de 1995.

\begin{tabular}{|c|c|c|c|c|c|}
\hline Clone & $\begin{array}{c}\text { Gema } \\
\text { floral emitida }\end{array}$ & $\begin{array}{c}\text { Botão } \\
(\%)\end{array}$ & $\begin{array}{l}\text { Flor } \\
(\%)\end{array}$ & $\begin{array}{c}\text { Fruto } \\
\text { imaturo } \\
(\%)\end{array}$ & $\begin{array}{c}\text { Fruto } \\
\text { maduro } \\
(\%)\end{array}$ \\
\hline Tabatinga & $1417,00 a^{*}$ & 46,22 & 52,93 & 0,61 & 0,24 \\
\hline Tefé & $873,00 \mathrm{ab}$ & 43,97 & 54,56 & 1,03 & 0,42 \\
\hline Muaná1 & $702,00 \mathrm{ab}$ & 9,50 & 87,28 & 2,04 & 1,19 \\
\hline Coari & $334,67 \mathrm{a} \mathrm{b}$ & 37,95 & 60,15 & 1,30 & 0,60 \\
\hline Anamã & $277,33 a \mathrm{~b}$ & 11,18 & 81,97 & 4,93 & 1,92 \\
\hline Muaná2 & $173,00 \quad b$ & 32,76 & 61,27 & 3,66 & 2,31 \\
\hline Média & 629,50 & 34,96 & 62,85 & 1,43 & 0,71 \\
\hline C.V. $(\%)$ & 13,20 & - & - & - & - \\
\hline
\end{tabular}

* Médias na mesma coluna seguidas pela mesma letra não diferem estatisticamente pelo teste de Tukey, ao nivel de $5 \%$ de probabilidade. 
derrubaram as folhas, indicando possivel translocação de nutrientes para sustentar a frutificação.

O percentual de gemas florais derrubadas na fase de botão floral em 1995 foi significativamente superior $(T=-2,84 ; G . L .=6,2$; $\mathrm{P}<0,05)$ do que o de 1994, pois, além do fator nutricional que pode ter influenciado, a menor quantidade de gemas florais provavelmente aumentou a incidência de doenças e pragas que atingem o botão floral, como o curculionídeo Derelomus chamaeropsis (Neves et al., 1993c) ou Baris sp. (Venturieri, 1994). Este curculionídeo, classificado em gêneros diferentes pelos autores acima referidos, ataca os botões do cupuaçuzeiro, na forma larval. Porém, o mesmo inseto é referido como polinizador pelos mesmos autores. Jardim (1991) o reconheceu também como polinizador do açaízeiro, sendo que a utilização destas duas culturas no mesmo local, deve causar aumento na população deste inseto e, consequentemente, grande ataque aos botões florais do cupuaçuzeiro. Para que estas duas espécies sejam usadas em consórcio faz-se necessário um estudo mais completo dos danos e beneficios causados pelo inseto.

A queda de gema floral na fase de botão no ano de 1995 foi marcante nos clones Tabatinga (46,22\%) (Tabela 1) e Tefé $(43,97 \%)$ (Tabela 2). O primeiro apresentou maior quantidade de "vassoura de bruxa", doença que ataca principalmente a extremidade dos ramos, local em que se encontra a maior incidência de botões, enquanto no clone Tefé foram encontradas colônias de formigas vivendo em simbiose com afídeos que se alimentam da seiva retirada da base do botão, local em que fazem seu ninho, provocando danos à floração. Em 1994, ano em que ocorreu grande floração, portanto, com muito alimento, esta associação parece não ter causado muito dano. 
O percentual médio de gemas florais que atingiu 0 estádio de flor foi maior em 1994 (88,63\%) que em 1995 (62,85\%) (Tabelas 1 e 2); com diferença altamente significativa ( $T=3,43 ; G . L .=10$; $P<0,01)$. Portanto, quanto maior a floração, maior a probabilidade das gemas florais chegarem até o estádio de flor aberta.

O percentual de flores que são fertilizadas e iniciam o desenvolvimento de fruto foi $1,03 \%$ (1994) e 3,38\% (1995), indicando que entre 98,16 (1994) e 29,6 (1995) flores emitidas, uma inicia a formação do fruto. $O$ nivel de fruto iniciado variou significativamente entre os anos ( $T=$ - 2,47; G.L. $=6 ; P<0,05)$. O percentual médio de frutos iniciados no período foi de $2,2 \%$, e entre 63,88 flores emitidas apenas uma iniciou 0 desenvolvimento do fruto. Este valor é maior do que 0,89\% encontrado por Falcão \& Lleras (1983), em trabalho realizado no Estado do Amazonas. Provavelmente, esta diferença se deva ao material genético, ambiente diferente $\mathrm{e}$ ao fato de que os dados foram obtidos por estimativa.

O cupuaçuzeiro é uma planta que apresenta grande investimento em flor e somente uma pequena parte é transformada em fruto. No período estudado, a proporção de flor:fruto maduro foi de $0,19 \%$ (1994) e 1,08\% (1995) indicando que entre 538,12 (1994) e 92,22 (1995) flores emitidas, uma atingiu o estádio de fruto maduro. $O$ nivel de frutificação variou significativamente no período ( $T=-2,57$; G.L. $=5,2$; $\mathrm{P}<0,05)$. $O$ percentual médio de frutos que atingiu a maturação no período foi de $0,64 \%$, e a proporção flor:fruto maduro foi de 315,07 .

A taxa de vingamento, frutos iniciados que completaram o desenvolvimento até a maturação foi de $25,17 \%$, sendo considerado as doenças, pragas, nutrição e questões climáticas os principais causadores do grande percentual de frutos derrubados ainda 
imaturos. Esse percentual é bem inferior aos 61,87\% encontrado por Falcão \& Lleras (1993) e 67\% encontrado por Venturieri (1994), provavelmente devido aos mesmos terem trabalhado com árvores maiores e os dados terem sido obtidos através de estimativa.

Na Figura 7, observa-se o percentual médio de gemas florais que são derrubadas na fase de botão floral, flor aberta, fruto imaturo e fruto maduro, no cupuaçuzeiro, demonstrando que esta, assim como outras espécies tropicais amazônicas, apresenta grande investimento na produção de gemas florais e somente um pequeno percentual completa o ciclo até a maturação do fruto, como observado por Purseglove (1968).

\subsection{Hipóteses que se propõem a explicar a proporção flor:fruto}

Como outros membros da floresta tropical, o cupuaçuzeiro produz grande quantidade de flores e apresenta baixo nível de frutificação.

Na literatura existem várias hipóteses não mutuamente exclusivas, que se propõem a explicar a grande quantidade de flores hermafroditas que são produzidas em relação ao pequeno número de frutos que completam o desenvolvimento até fruto maduro.

$\mathrm{Na}$ hipótese da macho função, parte das flores funciona como se fosse masculina, somente doando pólen, causando, dessa forma, aumento no denominador da proporção flor:fruto, o que resulta em baixo valor de frutificação. Neste trabalho, não foram encontradas evidências para sustentar esta hipótese, como detectado por Stephenson (1979) em Catalpa speciosa, onde após quatro flores terem sido polinizadas numa inflorescência contendo 27 flores hermafroditas, as 


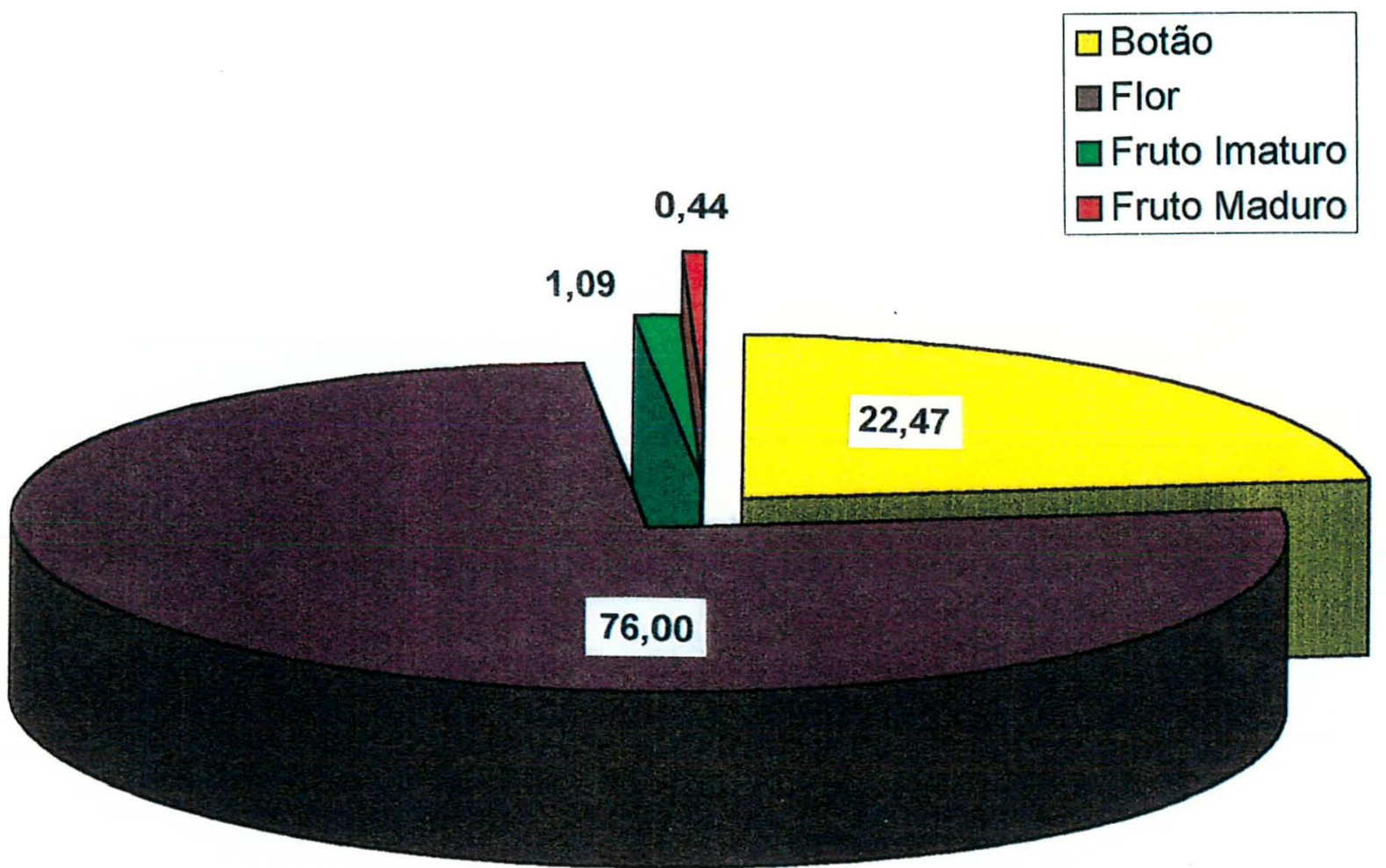

Figura 7: Potencial reprodutivo: percentual médio de gemas florais que foram derrubadâs nas fases de botão floral, flor, fruto imaturo e fruto maduro, em seis clones de cupuaçuzeiro (Theobroma grandiflorum), em Belém-PA, nos anos de 1994 e 1995. 
demais passam somente a doar pólen, pois a parte feminina das demais torna-se infértil. No cupuaçuzeiro as flores que vão abrindo ao longo do período de florescimento são viáveis, independente do número de frutos que foram iniciados.

A hipótese de atração do polinizador somente é relevante se a planta requer polinizadores para que ocorra a frutificação. No caso do cupuaçuzeiro, isto foi confirmado pelos resultados dos dois anos consecutivos do tratamento de exclusão do inseto, conforme resultados apresentados neste trabalho, e por Falcão \& Lleras (1983). No entanto, um pré-requisito adicional para sustentação dessa hipótese é que a frutificação seja limitada pela disponibilidade do pólen, sendo que o resultado do tratamento de polinização artificial suplementar realizado em 1994 exclui esta possibilidade, pois se a disponibilidade de pólen fosse um fator limitante, aumento da taxa de transferência de pólen (como simulado pela polinização suplementar) conduziria ao aumento da produção de frutos maduros, o que não foi constatado no presente trabalho.

Um critério que poderia ser usado para testar esta hipótese, seria o da visita preferencial dos polinizadores, já que estes preferencialmente visitam grandes inflorescências. Espera-se então, que o clone com maior floração, apresente maior frutificação. Porém, este critério não pode ser aplicado no presente trabalho pois, como os clones apresentaram-se auto-incompatíveis, o percentual de frutificação depende do grau de compatibilidade com os clones mais próximos. Portanto, o clone que apresentou maior floração poderia estar recebendo maior quantidade de visitas por parte do polinizador porém, esta polinização estaria sendo realizada com pólen originado do mesmo 
material genético (planta do mesmo clone) e por conseguinte este grande percentual de polinização não estaria resultando em grande frutificação.

Quando a análise é feita, a nível geral, fica evidente que a frutificação foi maior, quando ocorreu maior floração (ano de 1994), o que parece suportar a hipótese de atração. Porém, o tratamento de polinização controlada realizado, não é adequado para testar está hipótese, dessa forma os resultados encontrados, no presente trabalho, não oferecem completa base de sustentação para esta hipótese.

A hipótese de aborto seletivo prediz que se a polinização satisfatória é alta e o número de frutos iniciados é superior ao que a planta consegue sustentar, esta aborta seletivamente e somente completam o desenvolvimento aqueles frutos que são de "alta qualidade".

Embora o tratamento de polinização artificial, realizado no presente trabalho, não apresente base para afirmar se aumenta a produtividade, demonstrou-se que a quantidade de pólen não foi fator limitante, pois os frutos originados de polinização artificial foram derrubados da mesma forma que os de polinização aberta. Por outro lado, todos os frutos maduros apresentaram número de sementes equivalentes em todos os lóculos e, só raramente, apresentaram uma a duas sementes a mais por loja, demonstrando que, no cupuaçuzeiro, nem toda polinização satisfatória leva à formação de um fruto maduro, porém todo fruto maduro foi originado a partir de uma polinização satisfatória. Provavelmente, os frutos originados a partir de polinização inadequada, onde um número mínimo de óvulos por lóculo não foi fertilizado, foram seletivamente abortados.

Um outro fator que parece estar limitando a produtividade do cupuaçuzeiro é o aspecto nutricional, pois os produtores estão diminuindo a intensidade de queda de frutos imaturos com a 
utilização de adubação orgânica. É possivel que determinado local na planta receba mais assimilados do que outros, quando estes estão reduzidos, como ocorre em maçã, onde os frutos recebem assimilados preferencialmente das folhas mais adjacentes Hensen (1967).

Um terceiro fator que interfere no aborto de frutos imaturos é o período de menor precipitação pluviométrica que ocorre entre os meses de setembro à novembro, e esporadicamente periodos de 20 a 40 dias sem ocorrência de chuvas, o qual é denominado de "veranico", período em que os frutos estão em desenvolvimento. Porém, quando as chuvas voltam, também ocorrem perdas por rachadura nos frutos maiores, os quais racham formando fendas que quando atingem as sementes formam um local para entrada de patógenos causando a perda do fruto. Quando as rachaduras não atingem as sementes é possivel que ocorra a "cicatrização" e o fruto completa o seu desenvolvimento, conforme observado por Neves (dados não publicados).

O cupuaçuzeiro, em seu estado silvestre, parece não ser muito atingido por essas oscilações do clima, pois na floresta sobre 0 solo, existe uma camada de matéria orgânica que retém umidade, a qual supre as necessidades da planta. Em plantio experimental, foi observado que as plantas a pleno sol apresentam maiores perdas que as plantas sombreadas (ambiente mais próximo do hábitat natural) (Neves, dados não publicados).

Em plantios comerciais a pleno sol, local em que o cupuaçuzeiro tem se mostrado mais produtivo e apresentado menor incidência da doença "vassoura de bruxa", há necessidade de suplementação de água nesse pequeno período do desenvolvimento dos frutos. No municipio de Tomé-Açu, Sul do Estado do Pará, local onde o 
suplementação de água nesse pequeno período do desenvolvimento dos frutos. No municipio de Tomé-Açu, Sul do Estado do Pará, local onde o periodo sem chuvas é maior, foram estimadas perdas de até $40 \%$ para a safra 95/96 (Rafael Alves) ${ }^{1}$.

Os resultados encontrados no presente trabalho oferecem base de sustentação para esta hipótese, havendo, porém, necessidade de pesquisa com metodologia especifica para testá-la, como a realizada em Prunus mahaleb (Rosaceae) por Guitian (1994).

A frutificação nos clones de cupuaçuzeiro foi baixa durante o período de dois anos de desenvolvimento do trabalho. Os diferentes fatores responsáveis por este baixo nível provavelmente interagem, e seus efeitos provavelmente exibem variação no tempo e espaço. Parece que a espécie esta sob pressão seletiva, que mantém a produtividade de acordo com a capacidade de suporte da planta e aumento na produtividade somente será possivel com o aumento desta capacidade de suporte, através do fornecimento de água e nutrientes.

\subsection{Variação no início da floração dentro de clones}

O início do florescimento na plantas dentro dos clones apresentou grande variação, com situação onde todas as três plantas iniciaram a floração na mesma quinzena, caso observado no clone originado de Tabatinga-AM, e no outro extremo, a ocorrência de diferença de até 90 dias, clone originado de Tefé-AM.

A variação no início do florescimento observada nas repetições dentro dos clones, portanto entre plantas do mesmo material genético e localizadas em local relativamente uniforme, indica possivel 
compreensão deste fato. Em caso de comprovação, será necessário fazer seleção para a interação enxerto e porta-enxerto.

\subsection{Caracterização floral}

\subsubsection{Cor da flor}

A pigmentação das flores entre clones não foi muito discrepante (Figura 8), sendo o róseo-avermelhado a cor encontrada para os clones Muaná1, Tefé e Coari; vermelha para o clone Anamã e púrpura para o clone Muaná2. O clone Tefé apresentou pigmentação em outras partes da flor, como cúcula e sépala.

A variação encontrada na coloração da lâmina das pétalas dos clones, não é significativa para a espécie, pois Neves et al. (1992d) constaram 16 intensidades diferentes de pigmentação, variando desde a completa despigmentação ao vermelho intenso. A coloração róseo-avermelhada apresentada por três clones no presente trabalho, corresponde à coloração predominante, encontrada no trabalho citado anteriormente. $O$ caráter cor da flor serve com referencial para indicar a variabilidade dentro da espécíe e constitui um fator de grande importância, na atração de polinizadores. Em espécies que dependem de animais para promover o fluxo de pólen, é um caráter de grande importância.

Soria et al. (1982) e Alvim (1984), estudando duas populações de cacaueiro que apresentavam dimorfismo em relação à coloração da flor, não encontraram diferença significativa na produção de frutos entre os clones, constatando que nessa espécie, a coloração das lâminas não tem influência na atração dos polinizadores. Porém 


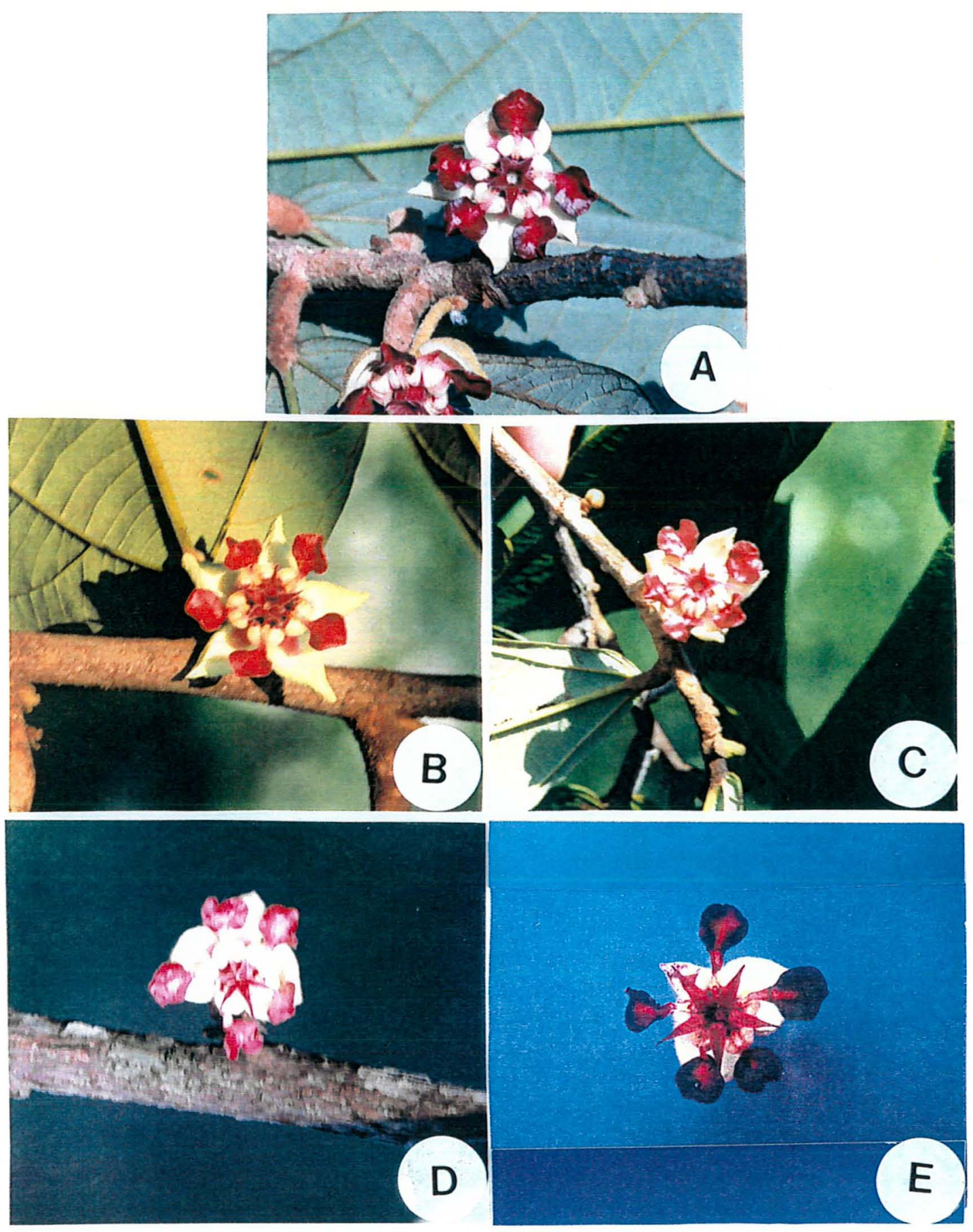

Figura 8: Flor aberta do cupuaçuzeiro. A - clone Muaná1, 3,69 cm; B clone Anamã $3,50 \mathrm{~cm}$; C - clone Tefé $3,46 \mathrm{~cm}$; D - clone Coarí $3,52 \mathrm{~cm}$; e E - clone Muaná2 $3,71 \mathrm{~cm}$. 
Venturieri (1996), enfatizou a influência da cor vermelha intensa na atração do besouro Chrysomelideo, inseto que utiliza as flores vermelhas para o acasalamento e promove a polinização do cupuaçuzeiro. É necessário agora descobrir o polinizador dos genótipos que apresentam as flores com outras tonalidades e despigmentadas.

\subsubsection{Estimativa da quantidade de grãos de pólen na flor}

O cupuaçuzeiro é uma espécie que apresenta grande quantidade de grãos de pólen em suas flores, que têm cinco conjuntos de estames com 15 anteras bitecas.

A quantidade de grãos de pólen produzida pela flor apresenta variação significativa a nivel de $5 \%$ de probabilidade pelo teste de Tukey, entre os clones estudados (Tabela 3), apresentando dois grupos bem distintos: o primeiro formado pelos clones Coarí, Tefé e Anamã, que apresentam flores menores; o segundo formado pelos clones que produzem as maiores flores (Muaná1 e Muaná2).

Portanto, os resultados permitem concluir que no cupuaçuzeiro a quantidade de grãos de pólen produzida é inversamente proporcional ao tamanho da flor.

Embora haja diferença significativa no número de grãos de pólen produzidos, a massa polínica total parece ser equivalente entre os dois tipos de planta, pois embora os clones de flor maior produzam menor número de grãos de pólen, estes foram individualmente de maior tamanho (observação visual).

Venturieri (1994) estimou o número de grãos de pólen por flor em dez plantas, a partir de uma amostra de dez flores por planta, utilizando a metodologia de diluição dos grãos de pólen num 
Tabela 3: Aptidão para macho função: Os valores são médias de número de grãos de pólen por flor e desvios-padrões baseados, em seis repetições, de cinco clones de cupuaçuzeiro (Theobroma grandiflorum).

\begin{tabular}{lll}
\hline Clone & Média \pm (DP) & \\
& & \\
\hline Coari & $90084 \pm 8883,78$ & a \\
Tefé & $86195 \pm 3871,87$ & a b \\
Anamã & $79701 \pm 3237,52$ & b c \\
Muaná2 & $76122 \pm 5437,24$ & c \\
Muanã1 & $74922 \pm 1688,75$ & $\mathrm{c}$ \\
\hline Média & 81404,67 & \\
C.V.(\%) & 6,45 & \\
\hline
\end{tabular}

* Médias na mesma coluna seguidas pela mesma letra não diferem estatisticamente pelo teste de Tukey, ao nível de $5 \%$ de probabilidade. 
meio líquido, e encontrou média de 88337 grãos de pólen por flor, com o C.V. igual a $15,7 \%$. No presente trabalho foi realizada a estimativa dos grãos de pólen por flor de cinco clones, a partir de uma amostra de seis flores, obtendo-se média de 81404,67 grãos de pólen com C.V. igual a $6,45 \%$, o que demonstra a boa condução do experimento e eficiência da metodologia utilizada.

\subsubsection{Viabilidade dos grãos de pólen}

A determinação da viabilidade dos grãos de pólen foi realizada pelo método indireto de coloração, constatando-se viabilidade superior a 95\%, indicando que a espécie não tem problema de viabilidade. Os grãos de pólen viáveis apresentam-se corados de vermelho, enquanto que os inviáveis, não coraram e/ou apresentam-se em menor tamanho.

Embora o método de coloração de pólen seja criticado por muitos autores, os resultados encontrados foram confirmados através do alto percentual de frutos iniciados resultante do tratamento de polinização controlada.

\subsubsection{Contagem de óvulos}

O cupuaçuzeiro apresenta o ovário pentalocular com muitos óvulos. Na Tabela 4 observa-se que não existe diferença significativa a nivel de $5 \%$ entre o número de óvulos por loja, o qual varia de 8,57 (clone Coari) a 10,47 (clone Anamã), sendo observado porém, diferença significativa no número de óvulos por ovário, formando três 
Tabela 4: Aptidão para função feminina: Os valores são médias de óvulos por lóculo, ovário e desvios-padrões e amplitude baseados em seis repetições em cinco clones de cupuaçuzeiro (Theobroma grandiflorum).

\begin{tabular}{ccccc}
\hline Origem & $\mathrm{N}$ & $\begin{array}{c}\text { Média de } \\
\text { óvulos/lóculo } \\
\text { no ovário }\end{array}$ & $\begin{array}{c}\text { Média de } \\
\text { onvios/ovário } \pm \text { D.P. }\end{array}$ & Amplitude \\
\hline Mauná1 & 6 & $9,90 \mathrm{a}$ & $49,20 \pm 0,56 \mathrm{~b}$ & $48-51$ \\
Muaná2 & 6 & $9,83 \mathrm{a}$ & $49,17 \pm 1,11 \mathrm{~b}$ & $45-52$ \\
Tefe & 6 & $9,33 \mathrm{a}$ & $46,67 \pm 0,84 \mathrm{~b}$ & $43-49$ \\
Coari & 6 & $8,57 \mathrm{a}$ & $42,83 \pm 0,95 \mathrm{c}$ & $40-46$ \\
\hline Média & 6 & 9,56 & 48,03 & $44,8-50,8$ \\
C.V. (\%) & - & 7,97 & 7,97 & - \\
\hline
\end{tabular}

* Médias na mesma coluna seguidas pela mesma letra não diferem estatisticamente pelo teste de Tukey, ao nivel de $5 \%$ de probabilidade. 
grupos: o primeiro pelo clone Anamã com o maior número de óvulos $(52,3)$, um segundo grupo formado pelos clones Muaná1 $(49,2)$, Muaná2 $(49,17)$ e Tefé $(46,67)$. O clone Coari foi o que apresentou menor número de óvulos por ovário $(42,83)$.

O número de óvulos por ovário variou de 40 (clone Coari) a 56 (clone Anamã) apresentando média de 48,03 (Tabela 4). 0 clone Anamã foi o clone que apresentou maior número de óvulos no ovário, sendo que estes eram, individualmente, de menor tamanho (Figura 9A), enquanto que o clone Coari apresentou ovário com menor número de óvulos, sendo que estes eram de maior tamanho do que os óvulos dos demais clones (Figura 9B), possibilitando a formação de sementes maiores.

Um fato interessante é que os clones Anamã (1 $326,83 \mathrm{~g}$ ), Coari $(1105,83 \mathrm{~g})$ e Tefé (1 119,17g) produzem frutos considerados grandes, enquanto Muaná1 (520g) e Muaná2 $(573,33 \mathrm{~g})$ produzem frutos pequenos, demonstrando, dessa forma, que fruto grande não necessariamente apresentará maior número de sementes, em decorrência do limitado número de óvulos existentes no ovário.

O número de sementes não é proporcional ao número de óvulos, pois este é um componente de produção muito variável que também depende do percentual de fertilização. Como o número de óvulos por ovário é caráter que não apresenta variação significativa dentro do clone, o número variado de sementes por fruto depende, principalmente, do percentual de fertilização e desenvolvimento do embrião na semente.

O aborto de frutos, é um fenômeno que vem sendo observado desde Darwin (1876), e vem sendo revisado por muitos autores, como Stephenson (1981), Bawa \& Webe (1984), porém, 


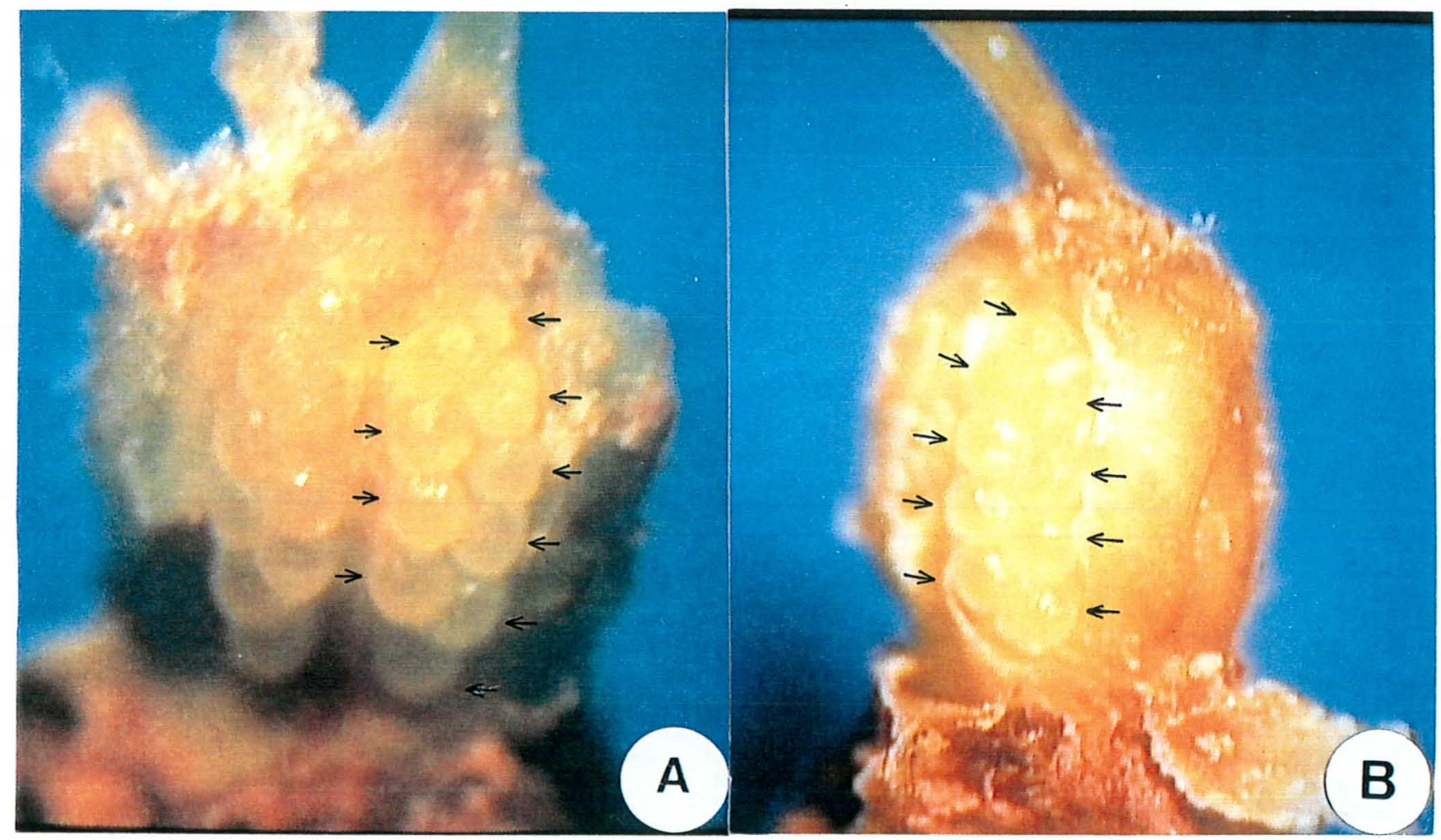

Figura 9: Ovário de cupuaçuzeiro após a remoção da parede. A: ovário do clone Anamã e B: ovário do clone Coarí. As setas indicam a quantidade de óvulos num lóculo do ovário. 
informações de sobrevivência de óvulos em ovários em desenvolvimento em populações naturais, são raros.

A porcentagem de óvulos que transformam-se em sementes (proporção óvulo:semente, proporção $O: S$ ), é um referencial do potencial de fertilização. Na Tabela 5 observa-se que o cupuaçuzeiro pode ser classificado como uma planta perene arbórea com grande capacidade de conversão de óvulos em sementes, pois apresenta em média $70,78 \%$ dos óvulos transformados em sementes, percentual muito superior aos $32,7 \%$ encontrado por Wiens (1984) em plantas com essas características.

As espécies perenes apresentam ciclo vital longo, o que aumenta a exposição à predadores e patógenos, sendo sugerido ser esta a melhor explicação para o predomínio da alogamia como sistema reprodutivo, o qual favorece a recombinação genética e, consequentemente, apresenta maior oportunidade para formar recombinantes resistentes à essas moléstias.

\subsection{A relação entre tamanho de flor e percentual de frutos iniciados}

O tamanho da flor entre os clones apresentou diferença significativa ( $F=2,97 ; G . L .=4 ; P<0,05)$ sendo que, esta diferença não foi detectada pelo teste de Tukey a $5 \%$ de probabilidade (Tabelas 6 e 7 ).

Com o objetivo de testar a influência do tamanho da flor na frutificação, os clones com maior tamanho de flor (Muaná1 e Muaná2, Tabela 7) foram reunidos em um grupo e o outro grupo foi formado pelos demais clones. Não houve diferença significativa $(T=0,98$; $G . L .=8 ; P>0,05)$ no percentual de fruto iniciado, demonstrando que não 
Tabela 5: Potencial de conversão de óvulos em sementes. Número de óvulos por ovário foi baseado em amostra de seis ovários, porém o número de sementes por fruto foi obtido a partir de número variado de frutos, em cinco clones de cupuaçuzeiro (Theobroma grandiflorum).

Clone

Número de Número de
óvulos/ovário sementes/fruto

Fertilização

$(\%)$

\begin{tabular}{llll}
\hline Coraí & 42,83 & 29,75 & 69,46 \\
Tefé & 46,67 & 36,00 & 77,14 \\
Muaná1 & 49,20 & 34,97 & 71,08 \\
Muaná2 & 49,17 & 31,89 & 64,86 \\
Anamã & 52,30 & $\mathbf{3 7 , 3 3}$ & 71,38 \\
\hline Média & 48,03 & 33,99 & 70,78 \\
\hline
\end{tabular}


Tabela 6: Análise da variância do tamanho de flor em cinco clones de cupuaçuzeiro (Theobroma grandifflorum).

\begin{tabular}{cccc}
\hline Fonte de Variação & G.L. & Q.M. & F \\
\hline Clones & 4 & 8,26 & $0,0388^{*}$ \\
Resíduo & 25 & 2,78 & \\
Total & 29 & & \\
\hline
\end{tabular}

C.V. $(\%)=4,66$

G.L. $=$ Graus de Liberdade

Q.M. = Quadrado Médio

${ }^{*}=$ Significativo ao nivel de $5 \%$ pelo teste $\mathrm{F}$.

Tabela 7: Teste de Tukey para as médias de tamanho de flor em cinco clones de cupuaçuzeiro (Theobroma grandiflorum).

\begin{tabular}{cc}
\hline Clones & Médias \\
\hline Muaná2 & $37,123 \mathrm{a}^{*}$ \\
Muaná1 & $36,930 \mathrm{a}$ \\
Coarí & 35,157 a \\
Anamã & 35,033 a \\
Tefé & 34,583 a \\
\hline
\end{tabular}

* Médias na mesma coluna seguidas pela mesma letra não diferem estatisticamente pelo teste de Tukey, ao nivel de $5 \%$ de probabilidade. 
existiu influência do caráter tamanho de flor no início da formação de frutos.

Os clones com flor maior produziram um percentual $18 \%$ menor no número de flores, porém esta redução foi compensada pela tamanho da flor na atração dos insetos e formação de frutos iniciados.

\subsection{Determinação direta do sistema reprodutivo}

Segundo Bawa \& O'Malley (1987), a estimativa preliminar do percentual de autogamia em plantas da floresta tropical pode ser obtida a partir de observações da biologia floral e de polinizações controladas, porém estes métodos apresentam limitações: primeiro, a endogamia não depende exclusivamente da autofertilização já que pequeno tamanho populacional também pode causá-la; segundo, as polinizações controladas podem ser feitas em número reduzido de indivíduos, o que poderá mascarar a avaliação quantitativa do sistema de cruzamento; e terceiro, a altura das árvores dificulta as polinizações controladas. Todavia, as técnicas de eletroforese superam estas limitações e também têm a vantagem de oferecer informação sobre o nivel de variação genética presente nas populações.

Indubitavelmente, a análise do sistema reprodutivo através de marcadores moleculares é a melhor forma para se determinar a taxa de cruzamento que está ocorrendo na natureza, contudo fornece informação incompleta, pois os resultados obtidos se referem à condição que a planta se encontra e não o que poderia acontecer se esta estivesse em condição diferente. Por exemplo, em espécie que apresenta apomixia parcial, plantas que estejam localizadas a uma distância em que não 
possam receber pólen de outras, se mostrarão completamente apomíticas, apesar de serem capazes de promover troca gênica e somente não o fazem, devido à circunstância desfavorável em que se encontram.

As informações obtidas com os marcadores moleculares é o resultado de todo um processo que envolve polinização, fecundação, fertilização e desenvolvimento de sementes e/ou plântulas.

Quando o objetivo é estudar alteração no sistema reprodutivo da espécie que apresenta auto-incompatibilidade (objetivo do presente trabalho) a modificação no loco de incompatibilidade originada por mutação, que a transforme em autocompatível, somente será observado se houver vetor para realizar a autopolinização, caso contrário passará desapercebido.

Enquanto a análise do sistema reprodutivo utilizandose marcadores moleculares mostra o que está acontecendo em condição natural, estudos da biologia floral e polinização controlada explicam os resultados obtidos através da metodologia anterior e mostra ainda, o que poderia acontecer se esse material fosse colocado em condição de cultivo.

Portanto, as questões levantadas pelos autores anteriores não deixam de estar corretas, porém o estudo de biologia floral e polinizações controladas, e marcadores isoenzimáticos e moleculares se completam para um melhor entendimento do sistema reprodutivo das espécies arbóreas tropicais. 


\subsubsection{Polinização aberta}

$\mathrm{Na}$ flor do cupuaçuzeiro observa-se o fenômeno de hercogamia, ou seja, ocorrem barreiras morfológicas formadas pelas cúculas e coroa de estaminódios, que impedem a autopolinização. A espécie apresenta, também, sistema de auto-incompatibilidade, o método mais eficiente de impedir a autofertilização, indicando que se trata de uma espécie alógama.

Venturieri (1994) classificou a abelha sem ferrão Plebeia minima como o polinizador efetivo do cupuaçuzeiro, embora, o horário de maior intensidade de abertura da flor não coincida com o horário em que abelha está no campo. Contudo existe um percentual de $25 \%$ das flores que abre ao longo do dia, podendo, portanto, ser eventualmente polinizado pela abelha, percentual muito superior aos $2 \%$ de polinização encontrado pelo autor e $2,2 \%$ de fertilização encontrado no presente estudo.

O fato do cupuaçuzeiro ser uma espécie que apresenta poucas flores abrindo num dia e longo período de floração, pode ser resultado da pressão seletiva a que estão submetidas as espécies que apresentam alogamia como forma do sistema reprodutivo.

Os resultados do tratamento para verificação da polinização natural mostram que o percentual de fertilização (frutos iniciados) foi de 1,24\% em 1994 e de 4,38\% em 1995, e a taxa de vingamento (frutos que completaram o desenvolvimento) foi de $16,67 \%$ (1994) e 35,43\% (1995) (Tabela 8). 
Tabela 8: Determinação direta do sistema reprodutivo em função do sistema de polinização. Os valores foram obtidos de três repetições em cinco clones de cupuaçuzeiro (Theobroma grandiflorum) em Belém-PA, nos anos de 1994 e 1995.

$\begin{array}{llllll}\text { Sistema de } & \text { Número } & \text { Número } & \text { Percentual } & \text { Número } & \text { Percentual } \\ \text { polinização } & \text { de flores } & \text { de frutos } & \text { flor/fruto } & \text { de frutos } & \text { de fruto } \\ & & \text { iniciados } & \text { iniciado } & \text { maduros } & \text { maduro }\end{array}$

\begin{tabular}{|c|c|c|c|c|c|}
\hline \multicolumn{3}{|c|}{1994} & & & \\
\hline PAB & 73286 & 912 & 1,04 & 157 & 16,67 \\
\hline AGA & 75 & 0 & 0 & - & - \\
\hline APE & 75 & 0 & 0 & - & - \\
\hline APF & 75 & 0 & 0 & - & - \\
\hline PCR & 300 & 214 & 71,33 & 17 & 7,94 \\
\hline & 199 & & & & \\
\hline PAB & 5093 & 223 & 4,38 & 79 & 35,43 \\
\hline AGA & 100 & 0 & 0 & - & - \\
\hline APE & 100 & 0 & 0 & - & - \\
\hline APF & 90 & 0 & 0 & - & - \\
\hline PCR & 355 & 281 & 79,16 & - & - \\
\hline
\end{tabular}

PAB: Polinização aberta

AGA: Agamospermia

APE: Autopolinização espontânea

APF: Autopolinização forçada (gueitonogamia)

PCR: Polinização cruzada. 


\subsubsection{Agamospermia}

Os resultados na Tabela 8 indicam que o cupuaçuzeiro requer polinização para que ocorra a formação de frutos. Mostram, também, que as 100 flores protegidas ao longo do periodo da floração do ano de 1995 não iniciaram frutos, indicando que a espécie não muda o seu comportamento reprodutivo para tornar-se agamospérmica no decorrer do florescimento.

\subsubsection{Autopolinização espontânea}

Na Tabela 8 observa-se que não há formação de fruto quando a flor foi isolada. O sistema de hercogamia que a espécie apresenta é muito funcional e impede a aproximação dos grãos de pólen da mesma flor, sendo que esta característica não muda ao longo da floração.

Resultado semelhante ao obtido no presente trabalho foi constatado por Falcão \& Lleras (1983) que protegeram as flores com protetor confeccionado com o tecido filó.

\subsubsection{Autopolinização forçada (gueitonogamia)}

O sistema de auto-incompatibilidade existente na espécie mostrou-se muito eficiente, pois não houve formação de frutos, neste tratamento (Tabela 8). Os clones mostraram-se totalmente autoincompativeis.

As caracteristicas apresentadas pelo botão floral, submetido a autopolinização e polinização cruzada entre clones 
compativeis 24 horas após a operação eram praticamente as mesmas; o ovário tornava-se róseo, indicativo que o tubo polínico atingiu o ovário, porém com 48 horas o ovário dos botões autopolinizados começavam a amarelar e o pedúnculo tornava-se fino e raramente permanecia até as 72 horas.

Os clones estudados eram formados por três plantas que estavam dispostas em forma sequencial. Portanto, como estes se mostraram auto-incompativeis, a planta que ficava no meio, apresentava uma probabilidade de $50 \%$ e as das extremidades de $25 \%$ de não frutificar, pois as polinizações não resultaram em frutificação. Os experimentos que tenham a finalidade de testar clones quanto à produção, devem ser distribuidos no campo aleatoriamente, de modo que uma repetição não fique próxima da outra, para, dessa forma, maximizar a produção e todos os clones terem a mesma oportunidade de frutificarem.

\subsubsection{Polinização cruzada (xenogamia)}

Os resultados da Tabela 8 mostram que os percentuais de frutos iniciados a partir de polinização artificial foram de $71,33 \%$ e $79,16 \%$, nos anos de 1994 e 1995, respectivamente. Porém quando foram utilizados somente os cruzamentos compativeis, os percentuais de frutos iniciados foram de 88,75\% em 1994 e de 92,13\% em 1995. Portanto, entre os cruzamentos compatíveis o percentual foi de $90,44 \%$ no período estudado.

Em cruzamento compativel, o ovário aumentava de tamanho e tornava-se mais róseo e o pedúnculo tornava-se mais grosso e permanecia verde 72 horas após a polinização, aos 12 dias 
apresentava a coloração marrom caracteristica do fruto maduro. Aos 30 dias apresentava crescimento longitudinal (Figura 10).

No ano de 1994 foram realizadas todas as 15 polinizações programadas (Tabela 9), porém em 1995 não foram realizadas todas as 20 polinizações programadas, em virtude da reduzida floração, contudo foram realizadas, no mínimo, 15 polinizações (Tabela 10), o que equivale a uma amostra equivalente a três vezes a utilizada por Warren et al. (1995a) para detecção de incompatibilidade em cacaueiro.

Nos cruzamentos realizados, em 1994, observou-se reação de incompatibilidade entre as combinações Tabatinga $\times$ Coari e Muaná1 x Muaná2. Em virtude da pequena quantidade de flores produzidas pelo clone Tabatinga, este foi substituído pelo clone Tefé em 1995, que se mostrou compatível com o clone Coarí, sendo que a combinação Muaná1 x Muaná2, manteve-se incompativel (Tabelas 9 e 10). As características apresentadas pelos cruzamentos incompatíveis foram semelhantes as de autopolinização.

A incompatibilidade intra-especifica em cupuaçuzeiro, foi detectada por Venturieri (1994) mas, como o autor não protegeu as flores polinizadas, então restam dúvidas a respeito dos resultados encontrados.

A incompatibilidade mostrou-se bilateral (Tabelas 9 e 10), ou seja, o sistema de incompatibilidade pode estar agindo no pólen e óvulo, conforme observado por Knight \& Rogers (1955) trabalhando com cacaueiro, porém como o número de clones trabalhado é pequeno não se pode tirar conclusões definitivas.

Num total de 655 flores polinizadas envolvendo cruzamentos foi obtido um percentual de $75,25 \%$ de frutos iniciados aos 


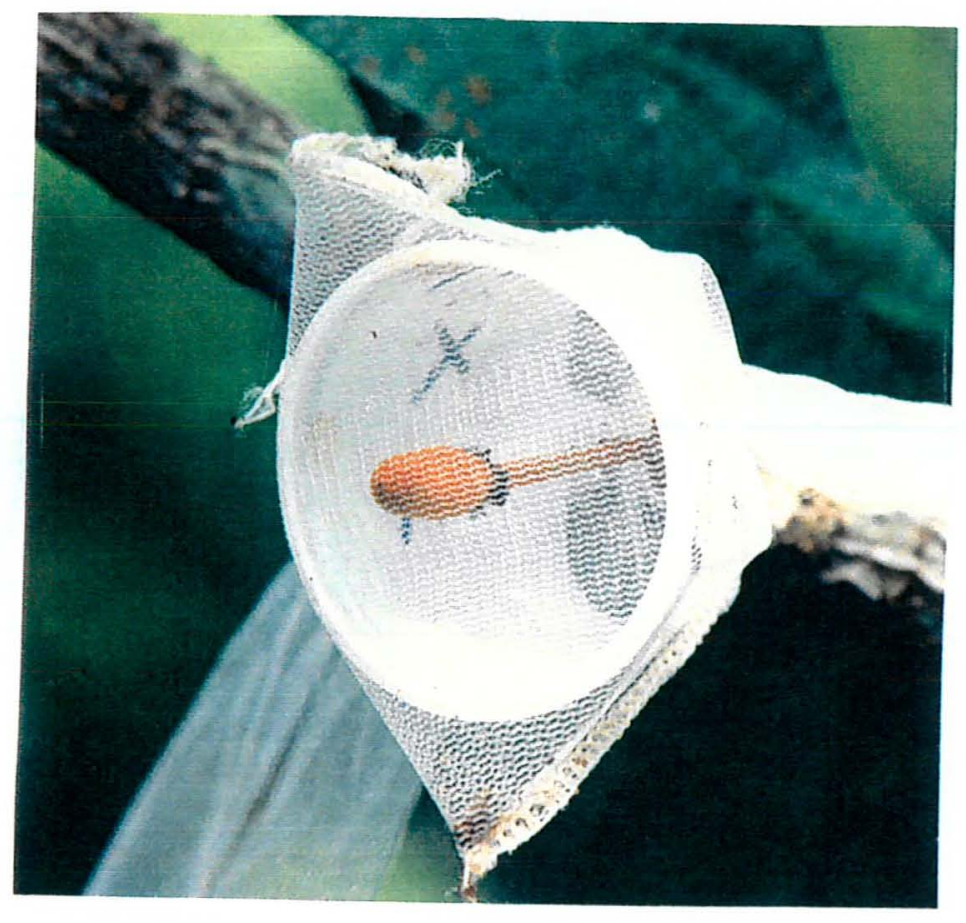

Figura 10: Fruto imaturo resultante do cruzamento Muaná1 x Coarí aos 30 dias após à polinização protegido pelo PRAMP. 
Tabela 9: Determinação direta do sistema reprodutivo: tratamentos de autopolinização e polinização cruzada. Número de polinizações realizadas, avaliação da fertilização aos quinze dias, percentual de fertilização e frutificação após seis meses da polinização, em cinco clones de cupuaçuzeiro (Theobroma grandiflorum) em Belém-PA no ano de 1994.

\begin{tabular}{|c|c|c|c|c|}
\hline$q^{\text {Polinização }}$ & $\begin{array}{l}\text { Número de } \\
\text { polinizações }\end{array}$ & $\begin{array}{c}\text { Avaliação aos } \\
15 \text { dias }\end{array}$ & $\begin{array}{c}\text { Fertilização } \\
\%\end{array}$ & $\begin{array}{c}\text { Número de } \\
\text { frutos } \\
\text { maduros }\end{array}$ \\
\hline Mua1 x Mua1 & 15 & 0 & 0 & 0 \\
\hline Mua1 x Ana & 15 & 13 & 86,67 & 1 \\
\hline Mua1 $\times$ Tab & 15 & 14 & 93,67 & 2 \\
\hline Mua1 $\times$ Coa & 15 & 15 & 100,00 & 3 \\
\hline Mua1 $\times$ Mua2 & 15 & 0 & 0 & 0 \\
\hline Ana x Mua1 & 15 & 14 & 93,33 & 2 \\
\hline Ana x Ana & 15 & 0 & 0 & 0 \\
\hline Ana $\times$ Tab & 15 & 12 & 80,00 & 0 \\
\hline Ana $\times$ Coa & 15 & 14 & 93,33 & 1 \\
\hline Ana $\times$ Mua2 & 15 & 13 & 86,67 & 1 \\
\hline Tab x Mua1 & 15 & 13 & 86,67 & 0 \\
\hline Tab x Ana & 15 & 12 & 80,00 & 1 \\
\hline Tab $\times$ Tab. & 15 & 0 & 0 & 0 \\
\hline Tab $\times$ Coa & 15 & 0 & 0 & 0 \\
\hline Tab x Mua2 & 15 & 13 & 86.67 & 0 \\
\hline Coa x Mua1 & 15 & 14 & 93,33 & 2 \\
\hline Coa x Ana & 15 & 13 & 86,67 & 1 \\
\hline Coa $\times$ Tab & 15 & 0 & 0 & 0 \\
\hline Coa x Coa & 15 & 0 & 0 & 0 \\
\hline Coa x Mua2 & 15 & 15 & 100,00 & 1 \\
\hline Mua2 $\times$ Mua1 & 15 & 1 & 6,67 & 0 \\
\hline Mua2 x Ana & 15 & 14 & 93,67 & 0 \\
\hline Mua2 x Tab & 15 & 12 & 80,00 & 1 \\
\hline Mua2 x Coa & 15 & 12 & 80,00 & 1 \\
\hline Mua2 $\times$ Mua2 & 15 & 0 & 0 & 0 \\
\hline Total & 375 & 214 & - & 17 \\
\hline
\end{tabular}


Tabela 10: Determinação direta do sistema reprodutivo: ao longo do periodo da floração: tratamentos de autopolinização e polinização cruzada. Número de polinizações realizadas, avaliação da fertilização aos quinze dias, percentual de fertilização em cinco clones de cupuaçuzeiro (Theobroma grandiflorum) em Belém-PA no ano de 1995.

\begin{tabular}{|c|c|c|c|}
\hline $\begin{array}{l}\text { Polinização } \\
9\end{array}$ & $\begin{array}{l}\text { Número de } \\
\text { polinizações }\end{array}$ & $\begin{array}{c}\text { Avaliação } \\
\text { aos } 15 \text { dias }\end{array}$ & $\begin{array}{c}\text { Fertilização } \\
\% \\
\end{array}$ \\
\hline Mua $1 \times$ Mua1 & 20 & 0 & 0 \\
\hline Mua1 x Ana & 20 & 17 & 85,00 \\
\hline Mua1 $\times$ Tefé & 20 & 17 & 85,00 \\
\hline Mua1 x Coa & 20 & 20 & 100,00 \\
\hline Mua1 x Mua2 & 20 & 0 & 0 \\
\hline Ana x Mua1 & 20 & 17 & 85,00 \\
\hline Ana x Ana & 20 & 0 & 0 \\
\hline Ana $\times$ Tefé & 20 & 18 & 90,00 \\
\hline Ana $\times$ Coa & 20 & 17 & 85,00 \\
\hline Ana $\times$ Mua2 & 20 & 19 & 95,00 \\
\hline Tefé x Mua1 & 20 & 19 & 95,00 \\
\hline Tefé x Ana & 15 & 13 & 86,68 \\
\hline Tefé $x$ Tefé & 20 & 0 & 0 \\
\hline Tefé x Coa & 15 & 12 & 75,00 \\
\hline Tefé x Mua2 & 17 & 13 & 76,47 \\
\hline Coa x Mua1 & 18 & 17 & 94,44 \\
\hline Coa x Ana & 16 & 14 & 87,50 \\
\hline Coa x Tefé & 15 & 13 & 86.68 \\
\hline Coa $\times$ Coa & 20 & 0 & 0 \\
\hline Coa x Mua2 & 18 & 16 & 88,89 \\
\hline Mua2 x Mua1 & 15 & 0 & 0 \\
\hline Mua2 x Ana & 15 & 13 & 86,68 \\
\hline Mua2 $\times$ Tefé & 15 & 12 & 80,00 \\
\hline Mua2 x Coa & 16 & 14 & 87,50 \\
\hline Mua2 $\times$ Mua2 & 15 & 0 & 0 \\
\hline Total & 450 & 281 & - \\
\hline
\end{tabular}


doze dias após a polinização. O percentual encontrado no presente trabalho foi superior aos $25,14 \%$ obtido por Venturieri (1994), provavelmente devido este autor ter realizado polinizações pela manhã e à tarde e ter trabalhado com plantas que apresentavam $15 \mathrm{~m}$ de altura, enquanto que no presente trabalho foi realizado no periodo da tarde, horário de maior intensidade de abertura da flor e receptibilidade do estigma e estilete e em plantas com $3,5 \mathrm{~m}$ de altura, o que permitiu maior comodidade para a realização das polinizações.

Em 1994, através da polinização artificial houve uma grande quantidade de frutos iniciados, porém a maior parte desses frutos foi eliminada como "peco" fisiológico (fruto que paralisou o crescimento, murcho e seco resultante de mecanismos internos através dos quais a planta elimina o excedente da produção) na mesma intensidade que os de polinização aberta, demonstrando que os frutos para serem mantidos na planta, não dependem somente de uma polinização satisfatória da flor que the deu origem. Estes resultados são semelhantes aos obtidos por Leite et al. (1990) trabalhando com cacaueiro. A produtividade do cupuaçuzeiro parece estar sob pressão seletiva que mantém a produção em determinada quantidade correspondente à capacidade de suporte da planta.

Não é descartada a possibilidade de haver preferência da planta em abortar frutos defeituosos (hipótese do aborto seletivo), sendo que em condição onde haja grande quantidade de frutos originados de flores que receberam polinização satisfatória este "excesso" também é descartado, como observado no tratamento de polinização cruzada entre os clones, no ano de 1994. Os resultados encontrados neste trabalho, mostram que a polinização manual não promove grande aumento na produtividade da planta, a não ser que sua capacidade suporte seja 
aumentada através da aplicação de fertilizantes, como constatado por Bawa \& Webe (1984), e Leite et al. (1990) e Warren et al. (1995a, b) trabalhando com cacaueiro.

Os resultados obtidos a partir do experimento de determinação direta do sistema reprodutivo do cupuaçuzeiro durante a floração mostrou que a mesma é uma espécie que não é capaz de formar fruto e semente sem que ocorra a polinização. Portanto o cupuaçuzeiro não é uma espécie agamospérmica.

Segundo o indice de auto-incompatibilidade proposto por Zapata \& Arroyo (1978) a espécie apresenta alto grau de autoincompatibilidade e também interincompatibilidade entre certos genótipos e alta capacidade de cruzamento, o que permite ser classificada como uma espécie alógama como forma do sistema reprodutivo.

O perfil do sistema reprodutivo não apresentou alteração, ao longo da floração, provavelmente devido ao fato de que a pressão ambiental exercida não foi suficiente para provocar mudanças. Os casos relatados na literatura de alteração no sistema reprodutivo, normalmente foram acompanhados por isolamento geográfico, em Sterculia Cola (Taroda \& Gibbs, 1982); altitude, em Eucalyptus pauciflora (Phillipis \& Brown, 1977); não existência de outras plantas para cruzar, em Canavanillesia platinafolia (Murawski \& Hamrick, 1992a). Venturieri (1994) relata o fato de um indivíduo de cupuaçuzeiro, isolado em BrasíliaDF, ter frutificado, o que indica que pressões ambientais possam quebrar as barreiras de auto-incompatibilidade. No caso dos clones estudados não foi observado quebra dessas barreiras. 


\subsection{Determinação indireta do sistema reprodutivo}

\subsubsection{Relação entre morfologia, viabilidade e sistema reprodutivo}

O diâmetro médio da flor do cupuaçuzeiro obtido a partir dos cinco clones foi de $35,77 \mathrm{~mm}$, maior que o exigido pelo método de determinação indireta do sistema reprodutivo baseado na morfologia e comportamento da flor, proposto por Cruden (1977), recebendo o peso 3 para esta característica.

$\mathrm{Na}$ flor do cupuaçuzeiro a antese (exposição dos órgãos reprodutivos à ação dos polinizadores) ocorre logo após o início da liberação das sépalas. A receptibilidade do estigma e estilete e a deiscência da antera começam ao mesmo tempo quando a flor ainda encontra-se fechada, sendo portanto uma flor homogâmica, atribuindo-se peso 0 para esta caracteristica. $\mathrm{Na}$ flor do cupuaçuzeiro é observado $\mathrm{O}$ fenômeno de hercogamia, separação espacial dos órgãos reprodutivos, recebendo peso 1 para esta caracteristica.

O somatório dos pesos atribuidos às características exigidas pelo método foi 4 , o que permite classificar o cupuaçuzeiro, segundo o índice de cruzamento, em parcialmente auto-incompatível, polinização cruzada ou apresentando demanda de polinizadores.

Segundo Cruden (1977) este método foi superado pelo método de determinação indireta do sistema reprodutivo através da proporção pólen:óvulo porém, o resultado encontrado neste experimento corrobora o encontrado na determinação direta do sistema reprodutivo, realizado através de polinização controlada.

O método é de grande utilização prática, pois permite estimar o sistema reprodutivo da espécie no local de coleta dos dados, 
o que é vantajoso para pesquisadores que estudam o sistema reprodutivo de espécies silvestres em seu habitat.

\subsubsection{Proporção pólen:óvulo (P:O)}

O cupuaçuzeiro apresenta alto investimento na produção de grãos de pólen e óvulo (Tabela 11).

A proporção pólen:óvulo apresentou variação entre os clones estudados, desde 1513,58 (clone Muaná1) a 2 103,29 (clone Coari) e apresentou média de 1692,41 o que permite classificar a espécie como xenógama facultativa.

Os resultados observados no presente experimento não foram confirmados pelos resultados obtidos no método de determinação direta do sistema reprodutivo realizado através de polinizações controladas, que classificou o cupuaçuzeiro como uma espécie xenógama obrigatória.

$\mathrm{Na}$ determinação do sistema reprodutivo baseado na morfologia e comportamento floral, obteve-se resultado semelhante aos obtidos pela polinização controlada, demonstrando ser mais eficiente na estimativa do sistema reprodutivo do cupuaçuzeiro que o método da proporção pólen:óvulo. Resultado oposto ao que foi encontrado por Cruden (1977) quando estimou o sistema reprodutivo de várias espécies utilizando os dois métodos e concluiu que a proporção pólen:óvulo era o método indireto mais eficiente de determinação do sistema reprodutivo. 
Tabela 11: Determinação indireta do sistema reprodutivo: proporção pólen:óvulo. Os valores são médias baseadas em seis repetições por clone para a produção de grãos de pólen e óvulos por ovário em cinco clones de cupuaçuzeiro (Theobroma grandiflorum).

\begin{tabular}{lccc}
\hline Clone & $\begin{array}{c}\text { Média do } \\
\text { número de } \\
\text { grãos de } \\
\text { pólen/flor }\end{array}$ & $\begin{array}{c}\text { Média do } \\
\text { número de } \\
\text { óvulos/flor }\end{array}$ & $\begin{array}{c}\text { Proporção } \\
\text { pólen:óvulo }\end{array}$ \\
\hline Coari & 90084 & 42,83 & 2103,29 \\
Tefé & 86195 & 46,67 & 1846,90 \\
Anamã & 79701 & 52,30 & 1523,05 \\
Muaná2 & 76122 & 49,17 & 1548,14 \\
Muaná1 & 74922 & 49,25 & 1513,58 \\
\hline Média & 81404,67 & 48,03 & 1692,40 \\
\hline
\end{tabular}


4.8. Relações genéticas entre os clones baseados em caracteres de morfologia floral e fruto.

\subsubsection{Análise univariada}

Na Tabela 12 são apresentados os resultados da análise da variância univariada referentes aos 19 caracteres, avaliados em cinco clones de cupuaçuzeiro. Verifica-se a existência de diferença altamente significativas entre médias dos clones, a $1 \%$ de probabilidade pelo teste de Tukey, para quatorze caracteres (LS, CL, LL, CC, DP, DEEA, NO, NP, PP, PC, PS, EC, CF e PF) a $5 \%$ de probabilidade para três caracteres (DF, CS e CP). Apenas dois caracteres não apresentaram diferença significativa entre as médias dos clones (LC e NS).

A grande diversidade constatada entre os clones, comprova os dados de observação obtidos através da coloração das lâminas das pétalas observadas por Neves et al. (1992d) e Calzavara et al. (1984) trabalhando com o formato do fruto para classificação das variedades.

Dessa forma, todos os caracteres foram empregados nos passos seguintes de estimação da diversidade genética baseada nas técnicas multivariadas.

A precisão na condução do experimento foi relativamente alta para os caracteres originados de flor, com coeficiente de variação (C.V.) abaixo de $6 \%$, exceto para o tamanho de pedúnculo que foi de $13 \%$. Os altos valores encontrados para os C.V. dos frutos foi, provavelmente, devido à natureza do material. 
Tabela 12: Resumo da análise da variância de 19 caracteres avaliados em cinco clones de cupuaçuzeiro no delineamento inteiramente casualizado.

\begin{tabular}{|c|c|c|c|c|c|c|c|c|}
\hline \multirow{2}{*}{$\begin{array}{l}\text { Fonte de } \\
\text { variação }\end{array}$} & \multicolumn{4}{|c|}{ Quadrado } & \multicolumn{2}{|c|}{ Médio } & \multirow[b]{2}{*}{$\begin{array}{c}\mathrm{CC} \\
(\mathrm{mm})\end{array}$} & \multirow[b]{2}{*}{$\begin{array}{c}\mathrm{LC} \\
(\mathrm{mm}) \\
\end{array}$} \\
\hline & $\begin{array}{c}\mathrm{CS} \\
(\mathrm{mm})\end{array}$ & $\begin{array}{l}\mathrm{LS} \\
(\mathrm{mm}) \\
\end{array}$ & $\begin{array}{c}\mathrm{CL} \\
(\mathrm{mm}) \\
\end{array}$ & $\begin{array}{c}\mathrm{LL} \\
(\mathrm{mm}) \\
\end{array}$ & \multicolumn{2}{|c|}{$\begin{array}{c}\mathrm{NP} \\
\text { (unid.) } \\
\end{array}$} & & \\
\hline Clone & $2,49^{\star}$ & $1,46^{\star \star}$ & $6,41^{\star \star}$ & $6,67^{\star \star}$ & \multicolumn{2}{|c|}{$256662862,00^{\star \star}$} & $0,36^{\star \star}$ & 0,20 \\
\hline Resíduo & 0,70 & 0,17 & 0,14 & 0,21 & \multicolumn{2}{|c|}{27607988} & 0,08 & 0,07 \\
\hline Média & 16,75 & 7,88 & 6,80 & 7,78 & \multicolumn{2}{|c|}{81404,67} & 5,90 & 5,88 \\
\hline CV (\%) & 4,99 & 5,30 & 5,48 & 5,88 & \multicolumn{2}{|c|}{6,46} & 4,73 & 4,57 \\
\hline Fonte de & \multicolumn{4}{|c|}{ Quadrado } & \multicolumn{2}{|c|}{ Médio } & \multirow{2}{*}{\multicolumn{2}{|c|}{$\begin{array}{l}P P \\
(g)\end{array}$}} \\
\hline variação & $\begin{array}{l}\mathrm{CP} \\
(\mathrm{mm})\end{array}$ & $\begin{array}{c}\mathrm{DP} \\
(\mathrm{mm})\end{array}$ & \multicolumn{2}{|c|}{$\begin{array}{c}\text { DEE-A } \\
(\mathrm{mm})\end{array}$} & $\begin{array}{l}\text { NO } \\
\text { (unid.) }\end{array}$ & $\begin{array}{c}\mathrm{NS} \\
\text { (unid.) } \\
\end{array}$ & & \\
\hline Clone & $20,98^{*}$ & $0,202^{\star \star}$ & \multicolumn{2}{|c|}{$0,54^{\star \star}$} & $74,42^{\star \star}$ & 61,80 & \multicolumn{2}{|c|}{$172936,25^{\text {** }}$} \\
\hline Resíduo & 5,52 & 0,004 & \multicolumn{2}{|c|}{0,04} & 5,37 & 34,41 & \multicolumn{2}{|c|}{12517,67} \\
\hline Média & 16,90 & 2,27 & \multicolumn{2}{|c|}{5,10} & 48,00 & 35,57 & \multicolumn{2}{|c|}{362,67} \\
\hline $\mathrm{CV}(\%)$ & 13,90 & 2,68 & \multicolumn{2}{|c|}{4,14} & 4,83 & 16,49 & \multicolumn{2}{|c|}{30,85} \\
\hline
\end{tabular}

\begin{tabular}{ccccccc}
\hline Fonte de & \multicolumn{7}{c}{ Quadrado } & Médio \\
\cline { 2 - 7 } variação & $\begin{array}{c}\mathrm{PC} \\
(\mathrm{g})\end{array}$ & $\begin{array}{c}\mathrm{PS} \\
(\mathrm{g})\end{array}$ & $\begin{array}{c}\mathrm{EC} \\
(\mathrm{cm})\end{array}$ & $\begin{array}{c}\mathrm{CF} \\
(\mathrm{cm})\end{array}$ & $\begin{array}{c}\mathrm{DF} \\
(\mathrm{mm})\end{array}$ & $\begin{array}{c}\mathrm{PF} \\
(\mathrm{g})\end{array}$ \\
\hline Clone & $137764,72^{\star \star}$ & $15257,87^{\star \star}$ & $0,13^{\star \star}$ & $198,95^{\star \star}$ & $3,34^{\star}$ & $779226,78^{\star \star}$ \\
Resíduo & 9236,20 & 1337,20 & 0,02 & 4,60 & 0,81 & 49213,03 \\
\hline Média & 420,07 & 146,47 & 0,72 & 18,30 & 10,18 & 929,03 \\
C.V. $(\%)$ & 22,88 & 24,97 & 19,84 & 11,72 & 8,85 & 23,88 \\
\hline
\end{tabular}

${ }^{* *} e^{*}$ : Significativo ao nivel de $1 \%$ e $5 \%$ de probabilidade pelo teste $F$, respectivamente.

1 - comprimento da sépala (CS)

2 - largura da sépala (LS)

3 - comprimento da lâmina da pétala $(\mathrm{CL})$

4 - largura da lâmina da pétala (LL)

5 - comprimento da cúcula (CC)

6 - largura da cúcula (LC)

7 - comprimento do pedúnculo $(\mathrm{CP})$

8 - diâmetro do pedúnculo (DP)

9 - distância do estigma-estilete a antera (DEE-A)

10 - número de óvulos (NO)
11 - número de grãos de pólen por flor (NP)

12 - número de sementes (NS)

13 - peso de sementes (PS)

14 - peso da casca (PC)

15 - peso da polpa (PP)

16 - peso do fruto (PF)

17 - espessura da casca (EC)

18 - comprimento do fruto (CF)

19 - diâmetro do fruto (DF) 
4.8.2. Estimativa da divergência genética obtida pela distância generalizada de Mahalanobis.

4.8.2.1. Análise de agrupamento pelo método de otimização de Tocher.

$\mathrm{Na}$ Tabela 13 são apresentadas as medidas de dissimilaridade entre cada par de clone, utilizando a distância generalizada de Mahalanobis. Observa-se que a amplitude das distâncias teve o máximo de 586,05 entre os clones Muaná2 e Tefé, e o mínimo de 29,57 entre os clones Muaná1 e Muaná2. Em termos genéticos, concluise que os clones Muaná2 e Tefé são os mais dissimilares, enquanto os clones Muaná1 e Muaná2 são os mais semelhantes.

Os grupos foram formados utilizando-se como referencial a maior distância existente no conjunto formado pelas menores distâncias entre cada par de clone. O valor do limite máximo para a inclusão de um clone no grupo, com referência às distâncias mínimas, foi de 238,79 .

Em decorrência da análise por este método, foram formados 3 grupos, apresentados na Tabela 14, no qual se verifica que 0 grupo I inclui dois clones 1 (Muaná1) e 5 (Muaná2); o segundo grupo também inclui dois clones, 2 (Anamã) e 4 (Coari). O clone 3 (Tefé) formou o terceiro grupo.

Pela análise das distâncias intra e intergrupos, apresentadas nas Tabelas 14 e 15 respectivamente, constata-se graus de divergência intragrupos diferente nos grupos I e II, cujas distâncias médias intragrupos foram de 29,55 e 181,75 , respectivamente. Isto indica que os clones que formam o grupo I (1 - Muaná1 e 5 - Muaná2) 
Tabela 13 - Medidas de dissimilaridade genética entre pares de clones de cupuaçuzeiro (Theobroma grandiflorum), fundamentadas na distância generalizada de Mahalanobis $\left(D^{2} i i i\right)$ a partir de 19 caracteres de morfologia floral e fruto.

\begin{tabular}{lccccc} 
Clone & Muaná1 & Anamã & Tefé & Coarí & Muaná2 \\
\hline Muaná1 & - & 221.36 & 482,31 & 374,82 & 29,57 \\
Anamã & & - & 238,79 & 181,75 & 312,99 \\
Tefé & & & - & 480,57 & 586,05 \\
Coarí & & & - & 371,88 \\
Muaná2 & & & & & - \\
\hline
\end{tabular}


Tabela 14 - Grupos com padrões de comportamento similares estabelecidos pelo método de otimização de Tocher, e distância média dentro de grupo, provenientes da avaliação de 19 caracteres da morfologia floral e fruto em cinco clones de cupuaçuzeiro (Theobroma grandiflorum).

\begin{tabular}{ccc}
\hline Grupo & Clone & Distância média \\
\hline I & 1 (Muaná) e 5 (Muaná2) & 29,57 \\
II & 2 (Anamã) e 4 (Coari) & 181,75 \\
III & 3 (Tefé) & - \\
\hline
\end{tabular}

Tabela 15 - Distâncias médias entre os grupos formados pelo método de otimização de Tocher, provenientes da avaliação de 19 caracteres da morfologia floral e fruto em cinco clones de cupuaçuzeiro (Theobroma grandiflorum).

\begin{tabular}{cccc}
\hline Grupo & I & II & III \\
\hline I & - & 320,26 & 534,18 \\
II & & - & 328,18 \\
III & & & - \\
\hline
\end{tabular}


apresentam maior similaridade que os clones Anamã e Coari que compõem o grupo $\|$.

Constata-se, também, que os maiores valores encontrados para a divergência genética entre os grupos foi de 534,18 entre os grupos I e III, indicando que o maior grau de heterose entre os clones estudados, é esperado do cruzamento entre os membros destes dois grupos, já que são os mais divergentes.

No presente trabalho foi observada correlação positiva entre a área geográfica e a divergência genética, pois os clones originados do Estado do Pará ficaram em grupo distinto dos originados do Estado do Amazonas. Isto ocorreu, possivelmente, em virtude de ser costumeiro a retirada das matrízes de cupuaçuzeiro que apresentam boas características agronômicas encontradas na floresta, para fazerem parte dos plantios de "fundo de quintal" das casas dos cablocos, local em que o material foi coletado para formar o banco de germoplasma, e utilizado na coleta dos dados do presente estudo.

Como o material é coletado na floresta existe maior probabilidade de ser plantado em local próximo de onde foi coletado, portanto é esperado que exista maior similaridade genética entre dois materiais cultivados na região, do que entre materiais pertencentes a locais distantes, conforme demonstraram os resultados encontrados no presente trabalho.

$\dot{E}$ importante salientar que trata-se de material, praticamente silvestre e, que portanto, não sofreu, ainda, influência de intercâmbio de germoplasma. Os resultados mostram que ainda não houve "mistura gênica" entre os clones dos dois Estados (Pará e Amazonas), o que caracteriza a "pureza genética" do material encontrado em cada região. 


\subsubsection{Análise de agrupamento utilizando o algoritmo de ligação média não ponderada.}

A técnica de agrupamento hierárquico aglomerativo fundamentado na distância generalizada de Mahalanobis, foi empregada na delimitação dos grupos formados pelos clones.

As relações entre os clones são mais claras quando apresentadas na forma de dendrograma o qual foi obtido utilizando-se o algoritmo de ligação média não ponderada (UPGMA) (Figura 11).

Um problema comum a todos os métodos de agrupamento é a dificuldade em se decidir quanto ao número de grupos presentes nos dados (Riboldi, 1986). Métodos informais para tal propósito, como o sugerido por Frieman \& Rubin (1967), baseiam-se na análise do dendrograma e verificação do ponto de alta mudança de nível, considerando isto como indicativo do número correto de grupos.

No presente trabalho não houve dificuldade na distinção dos grupos formados, pois além de ser pequena a quantidade de OTU's envolvidas, estas formaram três grupos distintos, possibilitando a delimitação dos grupos pela observação da alta mudança de nivel. No dendrograma observa-se que o maior salto, isto é, o maior acréscimo de distância, ocorreu no ponto em que o grupo formado pelos clones Muaná1 e Muaná2 originados do Estado do Pará, une-se ao outro grupo, composto pelos clones Anamã e Coari e o terceiro grupo formado pelo clone Tefé, originados do Estado do Amazonas. Dessa forma, observase uma maior distância genética do clone Tefé em relação ao grupo formado pelos clones Anamã e Coari, e ainda maior do grupo formado pelos clones Muaná1 e Muaná2. 


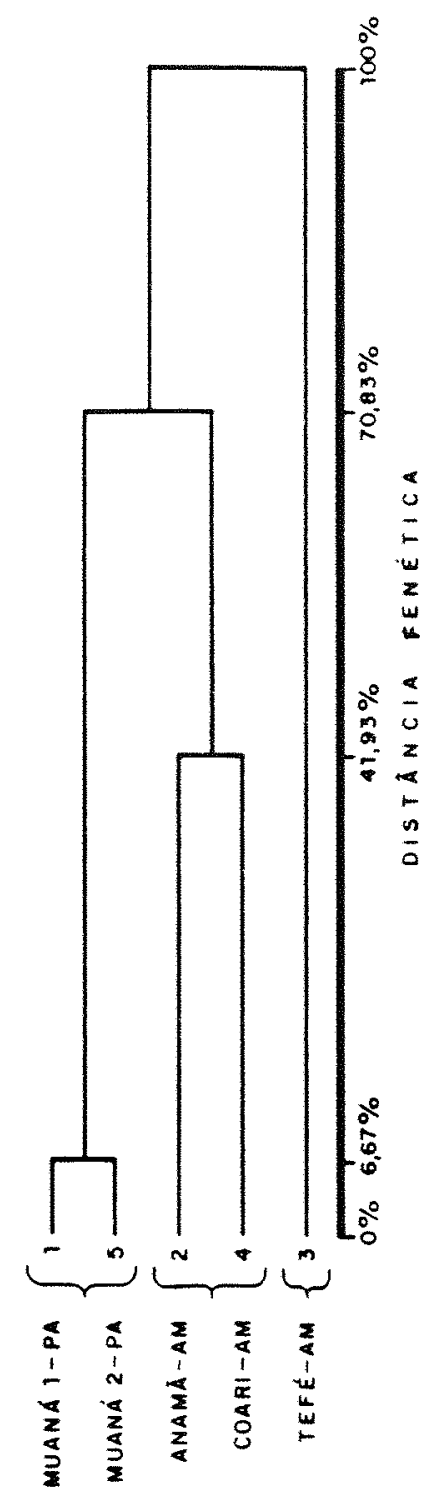

Figura 11: Dendrograma ilustrativo do padrão de similaridade estabelecido pelo método hierárquico aglomerativo de ligação média não ponderada (UPGMA), fundamentado na distância generalizada de Mahalanobis, utilizando 19 caracteres de flor e fruto, em cinco clones de cupuaçuzeiro (Theobroma grandiflorum). 
Estes dados coincidem com os obtidos pelo método de otimização de Tocher, com a formação do mesmo número de grupos e, em cada grupo os mesmos clones. Concordância na discriminação de grupos entre os dois métodos também foi obtida por Soares (1991), trabalhando com clones de batata-baroa e Amaral Júnior (1994) trabalhando com acessos de moranga.

Viana (1990) estudando a divergência genética entre 20 clones de cana-de-açúcar (Saccharum spp.), com base em oito caracteres, utilizando o método de otimização de Tocher, baseado na distância generalizada de Mahalanobis observou a formação de poucos grupos. Resultado semelhante foi obtido por Soares (1991) estudando a divergência genética entre 30 clones de batata-baroa (Arracacia xanthorrhiza Bancroft), utilizando a mesma metodologia. Os clones estudados formaram três grupos, sendo que somente o primeiro grupo conteve $86 \%$ dos genótipos estudados.

Cury (1993) estudando a variação fenética de 30 variedades de mandioca (Manihot esculenta Crantz), através do método de Tocher, fundamentado na distancia Euclideana média, constatou que as 14 variedades formaram quatro grupos fenéticos.

Souza (1996) estudando a divergência genética entre 13 acessos de aceroleira (Malpighia sp.) utilizando a mesma metodologia do autor anterior, constatou a formação de três grupos, sendo o primeiro composto por onze acessos.

Portanto, a formação de três grupos quando somente cinco clones foram avaliados, demonstra a grande variabilidade genética existente na espécie e o poder discriminatório dos caracteres utilizados. 


\subsubsection{Análise por variáveis canônicas}

A utilização das variáveis canônicas teve por finalidade simplificar os dados originais, de forma que as relações entre os clones, inicialmente influenciadas por um conjunto $\mathbf{p}$-dimensional $(p=$ número de caracteres iniciais) pudessem ser avaliadas num complexo bi-dimensional de fácil interpretação. Desta forma o método de variáveis canônicas permite reduzir o número inicial de caracteres sem que haja perda significativa de informação.

A eficácia do método depende da quantidade da variação total disponível contida nas $n$ (sendo $n<p$ ) primeiras variáveis canônicas. A importância de cada variável canônica é avaliada pela porcentagem da variação total por ela explicada, sendo arranjadas em ordem decrescente de variância. Assim a primeira variável canônica é definida como aquela de maior importância por reter a maior parte da variação total encontrada nos dados originais.

A Tabela 16 apresenta a correlação entre os caracteres originais e as quatro variáveis canônicas (CAN1, CAN2, CAN3 e CAN4). Observa-se que os duas primeiras variáveis canônicas exploram 90,21\% da variação total disponível. Baseados apenas nestas duas primeiras variáveis canônicas pode-se explicar satisfatoriamente a variabilidade entre os clones estudados.

Resultados com obtenção de altos valores para a variação total explorada pelas duas primeiras variáveis canônicas, também, foram observados por Resende (1991) estudando as relações fenéticas no gênero Laelia seção Parviflorae.

Como as duas primeiras variáveis canônicas envolveram a maior parte da variação total $(90,21 \%)$ seus escores, para 
Tabela 16: Correlação entre as variáveis originais e a estrutura canônica (CAN1, CAN2, CAN3 e CAN4). Origem das variáveis originais, porcentagem de informação retida pelas variáveis canônicas (\% variável) e ordenação das variáveis originais, conforme seu poder discriminatório obtido pela ponderação das quatro variáveis canônicas em relação ao percentual de informação contida pela variável.

Variável Origem CAN1 CAN2 CAN3 CAN4 Ordem

\begin{tabular}{llrrccc}
\hline DP & Flor & 0,720 & $-0,602$ & 0,149 & 0,130 & 1 \\
CF & Fruto & 0,672 & 0,495 & 0,427 & $-0,166$ & 2 \\
CL & Flor & $-0,910$ & $-0,096$ & $-0,234$ & 0,046 & 3 \\
PC & Fruto & 0,707 & 0,432 & 0,082 & $-0,196$ & 4 \\
LL & Flor & $-0,738$ & $-0,247$ & $-0,503$ & 0,068 & 5 \\
PF & Fruto & 0,714 & 0,328 & 0,283 & $-0,242$ & 6 \\
PS & Fruto & 0,597 & 0,412 & 0,360 & $-0,111$ & 7 \\
NP & Flor & 0,562 & 0,425 & $-0,338$ & 0,050 & 8 \\
DEE-A & Flor & $-0,808$ & 0,063 & $-0,089$ & 0,054 & 9 \\
PP & Fruto & 0,679 & 0,176 & 0,405 & $-0,297$ & 10 \\
LS & Flor & $-0,459$ & 0,569 & 0,072 & 0,269 & 11 \\
DF & Fruto & 0,583 & 0,222 & $-0,040$ & $-0,137$ & 12 \\
CP & Flor & $-0,441$ & 0,387 & 0,072 & $-0,244$ & 13 \\
CS & Flor & $-0,598$ & $-0,080$ & $-0,058$ & 0,015 & 14 \\
CC & Flor & $-0,434$ & 0,184 & 0,458 & 0,144 & 15 \\
NO & Flor & $-0,187$ & $-0,405$ & 0,679 & $-0,335$ & 16 \\
LC & Flor & $-0,422$ & 0,037 & 0,128 & 0,441 & 17 \\
NS & Fruto & 0,262 & $-0,251$ & 0,316 & 0,025 & 18 \\
EC & Fruto & 0,275 & 0,131 & $-0,668$ & 0,018 & 19 \\
\hline \% Variável & - & 57,11 & 33,11 & 8,97 & 0,82 & - \\
& & & & & & \\
Acumulada & - & 57,11 & 90,21 & 99,18 & 100 & - \\
\hline
\end{tabular}


cada clone, foram dispersos num gráfico bidimensional (Figura 12), onde a primeira e segunda variáveis canônicas, corresponderam aos eixos $X e$ $Y$, respectivamente. Constata-se que o clone mais distanciado em relação aos demais foi o 3 (Tefé), enquanto o clones 1 (Muaná1) e 5 (Muaná2), apresentam-se como os mais próximos. Estes resultados corroboram o obtido pelas técnicas de agrupamento aglomerativo e otimização de Tocher, fundamentadas na distância generalizada de Mahalanobis.

Levando em consideração o eixo CAN1 observa-se que as variáveis da flor apresentam valor discriminatório negativo, exceto o NP e DP, enquanto que as do fruto apresentam valor discriminatório positivo (Tabela 16 e Figura 8). Portanto clone com CAN1 grande, apresenta flor pequena e fruto grande, caracteristica dos clones Coarí (Figura $13 \mathrm{~A}$ e C), Anamã e Tefé, sendo que clone com CAN1 pequeno apresenta flor grande e fruto pequeno, características observadas nos clones Muaná1 (Figura 13 B e D) e Muaná2.

$\mathrm{Na}$ Figura 8 observa-se, também, a disposição das variáveis, assim como sua contribuição para a formação e distinção dos grupos. As variáveis $\mathrm{CL}, \mathrm{CS}$ e $\mathrm{LL}$, originadas da flor, apresentam correlação positiva com o primeiro grupo, enquanto as variáveis $P S, P C$, PF, CF, DF e PP originadas do fruto e NP originada da flor, estão correlacionadas positivamente com o segundo grupo e a variável DP apresenta correlação positiva com o terceiro grupo.

A importância dos caracteres de morfologia floral e fruto para a divergência genética entre os clones foi determinada através da ponderação entre cada variável canônica e porcentagem de variância por ela explicada. O critério adotado para determinação das variáveis de maior importância, constituiu-se na identificação das variáveis que apresentam os maiores valores absolutos resultantes da ponderação dos 


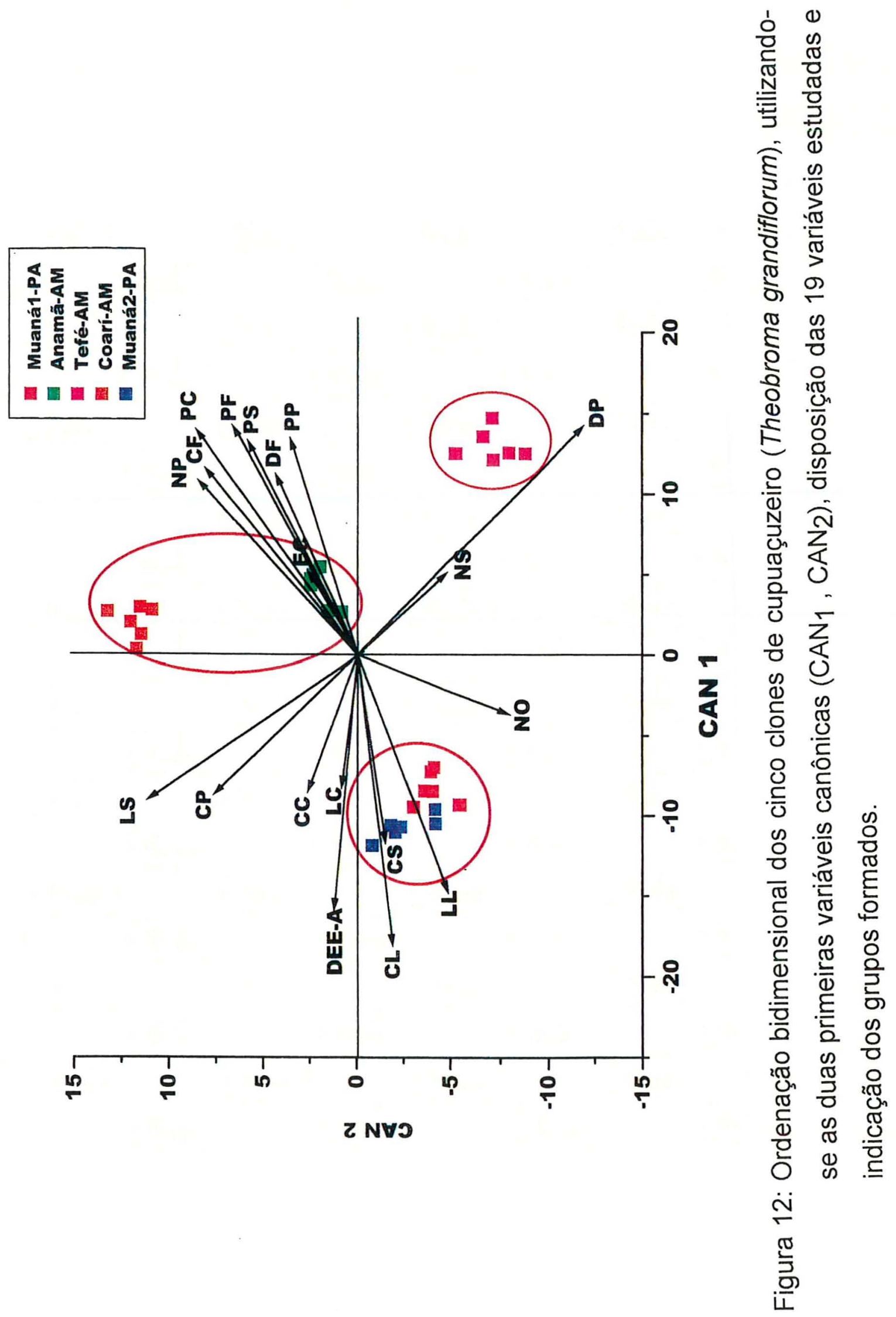




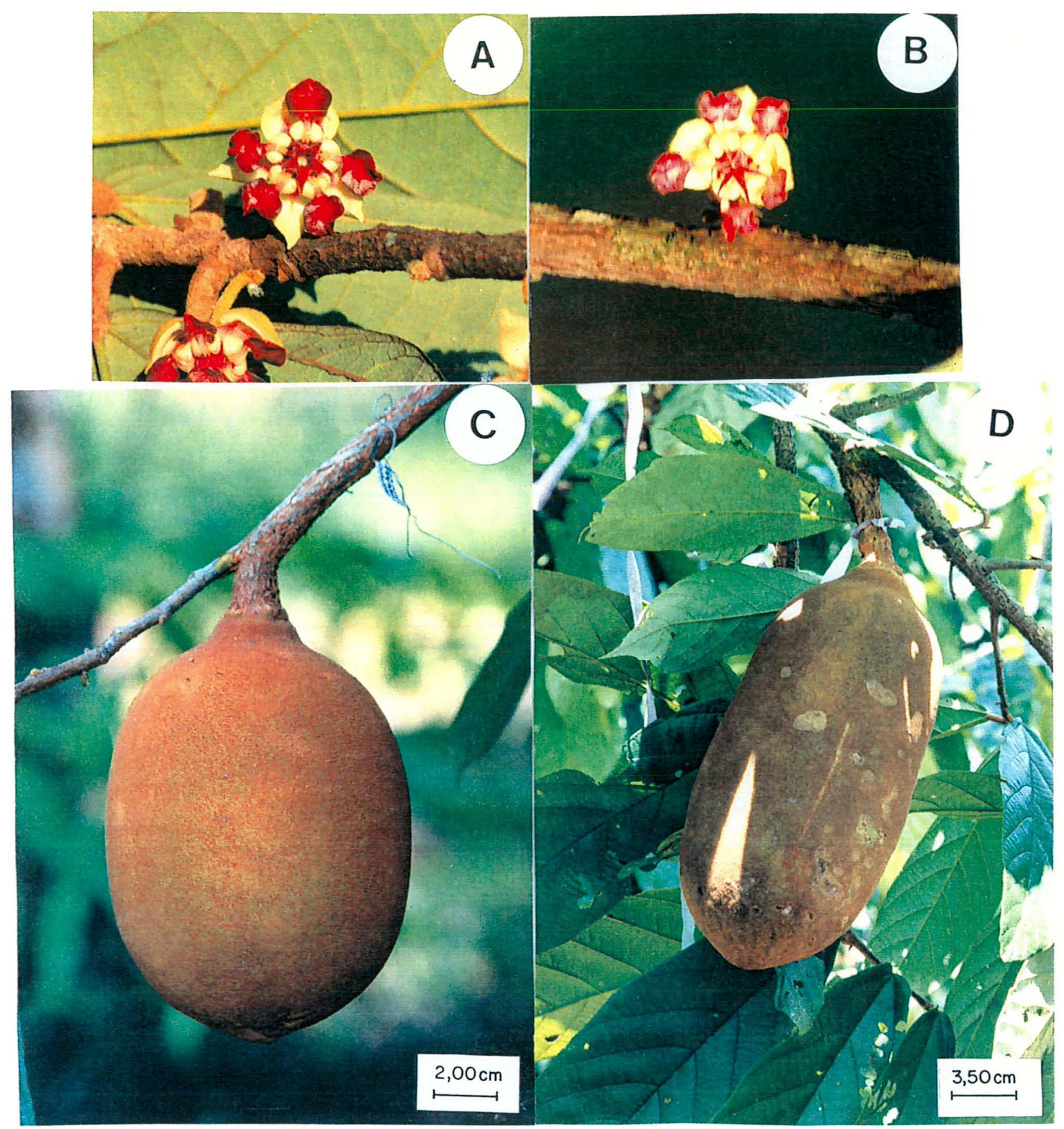

Figura 13: Flor e fruto do cupuaçuzeiro: A e C: flor e fruto do clone Muaná1. B e D: flor e fruto do clone Coarí. 
autovetores das quatro variáveis canônicas, e consequentemente, sendo critério inverso utilizado para identificar as variáveis com menor importância. Isto posto, conclui-se que os cinco caracteres mais discriminatórios foram, hierarquicamente, DP, CF, CL, PC e $L L$, sendo que três das cinco variáveis mais discriminatórias são oriundas de flor. As cinco variáveis menos discriminatórias, hierarquicamente, foram EC, NS, LC, NO e CC, sendo, novamente, três caracteres originados da flor. Estes resultados permitem concluir que as características morfológicas de flor e fruto apresentam peso discriminatório igual, resultado diferente do obtido para cacaueiro, onde os caracteres relacionados a flor apresentam maior poder discriminatório, constatado por Bekele et al. (1994), utilizando distância Euclideana média e componentes principais, em análise envolvendo caracteres quantitativos e qualitativos.

Informações mais completas a respeito da contribuição de cada variável para a análise de divergência podem ser obtidas a partir da utilização da Procedure STEP WISE do systems of analysis statistics (SAS) na versão 5.0 .

Os resultados dos métodos de análise multivariada de agrupamento e variáveis canônicas mostraram concordância na determinação da divergência genética, para os cinco clones estudados, separando três grupos fenéticos distintos, o primeiro formado pelos clones originados do Estado do Pará (Muaná1 e Muaná2); o segundo formado pelos clones Anamã e Coarí e o terceiro formado pelo clone Tefé, sendo estes últimos originados do Estado do Amazonas.

O número de clones utilizado no presente trabalho é pequeno para retirar conclusões definitivas a respeito da concordância entre divergência genética e região geográfica do cupuaçuzeiro e, para tanto, faz-se necessário estudos que envolvam maior número de clones e 
variáveis para obterem-se informações que possam ser extrapoladas para toda a espécie.

\subsection{Relação entre a divergência genética e compatibilidade entre os clones.}

A justificativa para manutenção do sistema de autoincompatibilidade é de evitar a autofertilização. Portanto, de certa forma, certas espécies de plantas evitam cruzamentos com parentais mais próximos geneticamente, como uma forma de buscar genes de outros locais e, dessa forma, ampliar sua base genética.

Como a forma mais rápida para atingir a homozigose é a autofertilização e todos os clones estudados apresentaram-se autoincompativeis e além do mais, os clones Muaná1 e Muaná2, que são muito próximos geneticamente, também mostraram-se interincompativeis, os resultados encontrados no presente trabalho, promovem base de sustentação para a hipótese de que a fertilização é impedida entre os indivíduos mais aparentados.

Embora Olmstead (1986) e Warren et al. (1995a) tenham demonstrado que o sistema de incompatibilidade pode ter evoluido independentemente do nivel de endogamia, em plantas muito heterozigotas como o cupuaçuzeiro, o cruzamento entre parentais muito próximos, geneticamente, é impedido através do sistema de incompatibilidade.

Contudo, os resultados encontrados neste estudo, não oferecem base para distinguir se o que está ocorrendo no cupuaçuzeiro é o efeito de um sistema de incompatibilidade com reação tardia no ovário, ou uma forte depressão endogâmica, devido à ação de genes deletérios 
encobertos pelo alto grau de heterozigosidade, que foram descobertos pela autofertilização ou fertilização cruzada entre parentais aparentados (clones Muaná1 e Muaná2), em virtude de serem oriundos de mesmo local, e apresentarem grande probabilidade de pertencerem a uma mesma população ancestral.

Por outro lado, quanto mais próximos geneticamente os clones, maior a probabilidade de carregarem o mesmo alelo do sistema de incompatibilidade. Para esclarecimento deste fato, a a utilização de marcadores moleculares e o sequenciamento do(s) gene(s) da incompatibilidade são ferramentas de fundamental importância. 


\section{CONCLUSÕES}

Considerando as condições em que foi realizado este trabalho, os resultados obtidos permitem apresentar as seguintes conclusões:

1 - O cupuaçuzeiro apresenta o modelo de floração em picos, com um principal e dois ou três menores, conforme o clone.

2 - A floração apresentou correlação negativa com a precipitação pluviométrica da região;

3 - A floração apresentou grande oscilação, com indicios de possivel bianualidade para a espécie.

4 - A espécie apresentou variação no número de óvulos no ovário, independente se o clone apresenta fruto grande ou pequeno.

5 - A pigmentação floral apresentou variabilidade, variando de róseo-avermelhado à púrpura.

6 - As flores maiores tendem a produzir grãos de pólen em menor quantidade, porém, individualmente, de maior tamanho. 
7 - Em cupuaçuzeiro, polinização satisfatória não significa que o fruto irá atingir a maturação, porém todo fruto maduro foi originado a partir de uma polinização satisfatória.

8 - O cupuaçuzeiro apresenta alta conversão de óvulos em sementes.

9 - O cupuaçuzeiro apresenta alto grau de auto-incompatibilidade, não aceita autofertilização e apresenta grang̛e receptividade ao pólen de origem genética diferente, portanto apresentando a alogamia como a forma predominante de reprodução.

10 - A espécie não apresenta agamospermia e o mecanismo de impedimento da autopolinização imposta pelo fenômeno da hercogamia é muito eficiente, pois impediu em $100 \%$ a autopolinização espontânea.

11 - A espécie não muda seu sistema reprodutivo ao longo do periodo da floração.

12 - O método de determinação indireta do sistema reprodutivo que tem por base a morfologia e o comportamento floral, mostrou-se mais adequado, que a proporção pólen:óvulo, como indicador do sistema reprodutivo.

13 - O método de agrupamento mostrou a formação de três grupos, o primeiro formado pelos clones originados do Estado do Pará e os outros dois formados com os clones originados do Estado do Amazonas. 
14 - Os clones mais próximos geneticamente evitam as trocas gênicas através do mecanismo de incompatibilidade.

15 - A formação de três grupos a partir de cinco clones demonstra a grande variabilidade genética existente na espécie e o poder discriminatório das variáveis originadas da morfologia floral e do fruto, possibilitam sua utilização na avaliação da divergência genética do cupuaçuzeiro.

16 - As variáveis originadas do fruto são tão discriminatórias, quanto às originadas da flor.

17 - Os clones que produziram as menores flores apresentaram os maiores frutos e vice-versa. 


\section{REFERÊNCIAS BIBLIOGRÁFICAS}

ADDISON, G.O.; TAVARES, R.M. Observações sobre as espécies do gênero Theobroma que ocorrem na Amazônia. Belém, Instituto Agronômico do Norte, 1951. 18p. (Boletim Técnico, 25).

AGREN, J. Between-year variation in flowering and fruit set in frostprone and frost-sheltered populations of dioecious Rubus chamaemorus. Oecologia, v.76, p.175-183, 1988.

AKER, C.L. Regulation of flower, fruit and seed production by a monocarpic perennial Yucca whipplei. Journal of Ecology, v.70, p.357-372, 1982.

ALVIM, P.T. Flowering of cocoa. Cocoa Growers' Bulletin, v.35, p.23-31, 1984.

AMARAL JÚNIOR, A.T. Análise multivariada e isozimática da divergência genética entre acessos de moranga (Cucurbita maxima Duchesne). Viçosa, 1994. 95p. Dissertação (Mestrado) Universidade Federal de Viçosa.

ASHTON, P.S. Speciation among tropical forest trees: some deductions in the light of recent evidence. Biological Journal of the Linnean Society, v.1, p.155-196, 1969.

AUBRÉVILLE, A. La forêt coloniale: les forêts de l'Afrique occidentale française. Annual Academic Science, v.9, p.1-245, 1938.

BAKER, H.G. Self-compatibility and establishment after "longdistance" dispersal. Evolution, v.9, p.347-348, 1955. 
BAKER H.G. Reproductive methods as factors in speciation in flowering plants. Cold Spring Harbor Symposia on Quantitative Biology, v.24, p.177-190, 1959.

BAKER, H.G.; BAWA, K.S.; FRANKIE, G.W.; OPLER, P.A. Breeding systems. In: GOLLEY, F.B., ed. Tropical rain forest ecosystems structure and function. Amsterdam: Elsevier, 1983. p.183-216.

BARBOSA, W.C.; NAZARE, R.F.R.; NAGATA, I. Estudos tecnológicos de frutas da Amazônia. Belém: CPATU, 1978. 19p. (EMBRAPA-CPATU. Comunicado Técnico. 3)

BARRETT, S.C.H.; ECKERT, C.G. Variation and evolution of mating systems in seed plants. In: KAWANO, S., ed. Biological approaches and evolutionary trends in plants. London: Academic Press, 1990. p.169-92.

BAWA, K.S. Breeding systems of tree species of a lowland tropical community. Evolution, v.28, p.85-92, 1974.

BAWA, K.S.; OPLER, P.A. Dioecism in tropical forest trees. Evolution, v.29, p.167-179, 1975.

BAWA, K.S.; WEBE, C.J. Flower, fruit and seed abortion in tropical trees: implications for evolution of paternal and maternal reproductive patterns. American Journal of Botany, v.71, p.736$751,1984$.

BAWA, K.S.; BULLOCK, S.H.; PERRY, D.R. Reproductive biology of lowland rain forest trees. 11. Pollination systems. American Journal of Botany, v.72, n.3, p.331-345, 1985.

BAWA, K.S.; O'MALLEY, D.M. Estudios genéticos y de sistemas de cruzamiento en algunas especies arbóreas de bosques tropicales. Revista de Biologia Tropical, 35(Supl. 1), p.177-188, 1987.

BEKELE, F.L.; KENNEDY, A.J.; LAUCKNER, F.B.; BEKELE, I. Numerical taxonomic studies on cocoa (Theobroma cacao) in Trinidad. Euphytica, v.75, p.231-240, 1994. 
BERTIN, R.I. Paternity in plants. In: LOVETT DOUST, J. \& LOVETT DOUST, L. ed. Plant reproductive ecology: patterns and strategies. New York: Oxford University Press, 1988. p.30-50.

BREWBAKER, J.L. Pollen cytology and incompatibility systems in plants. Journal Heredity, v.48, p.217-277, 1957.

BROWN, A.H.D. Genetic characterization of plant mating systems. In: BROWN, A. H.D.; CLEGG, M.T.; KAHLER, A.L.; WEIR, B.S., ed. Plant population genetics, breeding and genetic resources. Sinauer Associates, Sunderland, Massachusetts, USA., 1990. p.145-162.

BROWN, A.H.D.; BARRETT, S.C.H.; MORAN, G.F. Mating system estimation in forest trees: models, methods and meanings. In: GREGORIUS, H. R. ed. Population genetics in forestry. New York: Springer Verlag, 1985. p.32-49.

BRYNDUM, K.; HEDEGART, $H$. Pollination of teak (Tectona grandis L.). Silvae Genetica, v.18, p.77-80, 1969.

BULLOCK, S.H. Breeding systems in the flora of a tropical deciduous forest in Mexico. Biotropica, v.17, n.4, p.287-301, 1985.

CALZAVARA, B.B.G. Fruteiras: abieiro, abricozeiro, bacurizeiro, biribazeiro, cupuaçuzeiro. Belém, IPEAN, 1972. 42p. (IPEAN. Culturas da Amazônia v.1, n.2).

CALZAVARA, B.B.G.; MULLER, C.H.; KAHWAGE, O.N.C. Fruticultura tropical: o cupuaçuzeiro - cultivo, beneficiamento e utilização do fruto. Belém: EMBRAPA-CPATU, 1984. 101p. (EMBRAPA-CPATU. Documentos, 32).

CAMPBELL, R.B. The interdependence of mating structure and inbreeding depression. Theor. Pop. Biol., v.30, p.232-244, 1986.

CAMPBELL, R.B. Inflorescence size: test of the male function hypothesis. American Journal of Botany, v.76, p.730-738, 1989.

CARLETTO, G.M. O número de cromosômios em cacaueiros. Ilhéus: Instituto de cacau da Bahia, 1946. (Boletim Técnico, 6). 
CAVALCANTE, P.B. Frutas comestiveis da Amazônia II. Belém: Museu Paraense Emilio Goeldi, 1974. (Plublicações Avulsas, 17).

CAVALCANTE, P.B. Frutas comestiveis da Amazônia III. Belém: Museu Paraense Emilio Goeldi, 1976. (Plublicações Avulsas, 25).

CAVALCANTE, P.B. Frutas comestiveis da Amazônia. Belém: Museu Paraense Emilio Goeldi, 1991.

COPE, F.W. Some factors controlling the yield of young cocoa II. In: 8th ANNUAL REPORT ON COCOA RESEARCH, Trinidad, 1938. p.4-15.

COPE, F.W. Studies in the mechanism of self-incompatibility in cocoa-ll. In: 9th ANNUAL REPORT ON COCOA RESEARCH, Trinidad, 1939. p. 19-23.

COPE, F.W. The mechanism of pollen incompatibility in Theobroma cacao L. Heredity, v.17, p.157-182, 1962.

CLEGG, M.T. Measuring plant mating systems. BioScience, v.30, n.12, p.814-818, 1980.

CLEGG, M.T; EPPERSON, B. K. Recent developments in population genetics. Advances in Genetics, v.23, p.235-269, 1985.

CORREA, M.P. Dicionário das plantas úteis do Brasil e das exóticas cultivadas. Rio de Janeiro, Emprensa Nacional, 1926 1978. 6v.

COSTA, D.; MOTA, S.; CARVALHO, M.C. Sobre o valor nutritivo do doce de cupuaçu. Rio de Janeiro: SAPS, 1960. 6p. (Coleção Estudo e Pesquisa Alimentar, 14).

CORNER, E.J.H. The evolution of tropical forests. In: HUXLEY, J.; HARDY, A.C.; FORD, E.C. ed. Evolution as a process. Allen and Unwin, London. 1954. 
CRAWFORD, D.J.; ORNDUFF, R.; VASEY, M.C. Allozyme variation within and between Lasthenia minor and its derivative species, $L$. maritima (Asteraceae). American Journal of Botany, v.72, p.1177-1184, 1985.

CROAT, T.B. The sexuality of the Barro Colorado Island flora (Panama). Phytologia, v.42, p.319-348, 1979.

CRUDEN, R.W. Pollen-ovule ratios: a conservative indicator of breeding systems in flower plants. Evolution, v.31, n.1, p.32-46, 1977.

CRUZ, C.D. Aplicação de algumas técnicas multivariadas no melhoramento de plantas. Piracicaba, 1990. 188p. Tese (Doutorado) - Escola Superior de Agricultura "Luiz de Queiroz", Universidade de São Paulo.

CRUZ, C.D.; REGAZZI, A.J. Modelos biométricos aplicados ao melhoramento genético. Viçosa: Imprensa. Universitária, 1994.

CUATRECASAS, J.A. Cocoa and its allies: a taxonomic revision of the genus Theobroma. Contribution from the United States National Herbarium, v.35, p.32-46, 1964.

CURI, P. Análise multivariada. Botucatu, Apostila didática, 96p. 1991.

CURY, R. Dinâmica evolutiva e caracterização de germoplasma de mandioca (Manihot esculenta Crantz) na agricultura autóctone do Sul do Estado de São Paulo. Piracicaba, 1993. 103p. Dissertação (Mestrado) - Escola Superior de Agricultura "Luiz de Queiroz", Universidade de São Paulo.

DARWIN, C. The effects of cross- an self-fertilization in the vegetable kingdom. John Murray, London. 1876.

DAFNI, A. Pollination Ecology. New York: Oxford University Press, 1992. p.352.

DAMGAARD, C.; COUVET, D.; LOESCHCKE, V. Partial selfing as an optimal mating strategy. Heredity, v.69, p.289-295, 1992. 
DINIZ, T.D.A.S.; BASTOS, T.X.; RODRIGUES, I.A.; MÜLLER, C.H.; KATO, A.K.; SILVA, M.M.M. Condições climáticas em áreas de ocorrência natural e de cultivo de guaraná, cupuaçu, bacuri e castanha-do-Brasil. Belém, CPATU, 1984. (Pesquisa em andamento, 133).

DUCKE, A. As espécies brasileiras do gênero Theobroma $L$. Belém: Instituto Agronômico do Norte, 1953. 89p. (Boletim Técnico, 8).

EAST, E.M. The distribution of self-sterility in the flowering plants. Proc. Am. Phil. Soc., v.82, p.449-518, 1940.

EDWARDS, A.W.F.; CAVALLI-SFORZA, L.L. A method for cluster analysis. Biometrics, v.21, p.362-375, 1965.

EHRLÉN, J. Why do plants produce surplus flowers? A reserve-ovary model. American Naturalist, v.138, p.918-933, 1991.

ELLSTRAND, N.C.; TORRES, A.M.; LEVIN, D.A. Density and the rate of apparent outcrossing in Helianthus (Astereceae). Systematic Botany, v.3, p.403-407, 1978.

FAEGRI, K.; PIJL, L. van der. The Principles of Pollination Ecology. 3.ed. London: Sin. Ass., 1979. 224p.

FALCÃO, M.A.; LLERAS, E. Aspectos fenológicos, ecológicos e de produtividade do cupuaçu (Theobroma grandiflorum (Willd ex Spreng) Schum). Acta Amazônica, v.13, p.725-735, 1983.

FEDOROV, A.A. The structure of the tropical rain forest and speciation in the humid tropics. Journal of Ecology, v.54, p.1-11, 1966.

FRANKIE, G.W.; BAKER, H.G.; OPLER, P.A. Comparative phenological studies of trees in tropical wet and dry forests in the lowlands of Costa Rica. Journal of Ecology, v.62, p.881-913, 1974. 
FRIEMAN, H.P.; RUBIN, J. On some invariant criteria for grouping data. Journal of the American Statistical Association, v.62, p.1159-1178, 1967.

FRYXELL, P.A. Mode of reproduction of higher plants. Botanical Review, v.23, p.135-233, 1957.

GANDERS, F.R. The biology of heterostyly. New Zeland Journal of Botany, v.17, p.60-65, 1979.

GOTTLIEB, L.D. Genetic differentiation, sympatric speciation, and the origin of a diploid species of Stephanomeria. American Journal of Botany, v.60, p.545-553, 1973.

GUITIAN, J. Selective fruit abortion in Prunus mahaleb (Rosaceae). American Journal of Botany, v.81, n.12, p.1555-1558, 1994.

HAMILTON, M.B.; MITCHELL-OLDS, T. The mating system and relative performance of selfed and outcrossed progeny in Arabis fecunda (Brasssicaceae). American Journal of Botany, v.81, n.10, p.1252-1256, 1994.

HOLSINGER, K.E. Inbreeding depression doesn't matter: the genetic basis of mating-system evolution. Evolution, v.42, p.1235-1244, 1988.

HOLSINGER, K.E. Inbreeding depression and the evolution of plant mating systems. Trends in Ecology and Evolution, v.6, p.307308, 1991.

HOWELL, D.; ROTH, B. Sexual reproduction in agaves: the benefits of bats; cost de semeparous advertising. Ecology, v.62, p.1-7, 1981.

HENSEN, P. 14C-studies on apple trees. I. The effect of the fruit in the translocation and distribution of photosynthate. Physiologia Plantarum, v.2, p.382-392, 1967.

INOUYE, D.W.; GILL, D.E.; DUDASH, M.R.; FENSTER, C.B. A model and lexicon for pollen fate. American Journal of Botany, v.81, n.12, p.1517-1530, 1994. 
JAIN, S.K. The evolution of inbreeding in plants. Annual Review of Ecology and Systematics, v.7, p.469-495, 1976.

JAIN, S.K. Breeding systems and the dynamics of plant populations. In: INTERNATIONAL CONGRESS OF GENETICS, New Delhi, 1984. Proceedings. New Delhi, 1984. v.4, p.291-316.

JACOB, V.J. Self-incompatibility mechanism in Cola nitida. Incompatibility Newsletter, v.3, p.60-61, 1973.

JAMES, F.C.; MCCULLOCH, C.E Multivariate analysis in ecology and systematics: panacea or pandora's box? Annual Review of Ecology and Systematics, v.21, p.129-166, 1990.

JANZEN, D.H. Synchronization of sexual reproduction of trees within the dry season in Central America. Evolution, v.21, p.620-637, 1967.

JANZEN, D.H. Euglossine bees as long distance pollinators of tropical plants. Science, v.171, p.203-205, 1971.

JANZEN, D.H. A note on optimal mate selection by plants. American Naturalist, v.111, p.365-371, 1977.

JARDIM, M.A.G. Aspectos da biologia reprodutiva de uma população natural de açaízeiro (Euterpe oleracea) no estuário amazônico. Piracicaba, 1991. 90p. Dissertação (Mestrado) - Escola Superior da Agricultura "Luiz de Queiroz", Universidade de São Paulo.

KNIGHT, R.; ROGERS, H.H. Incompatibility in Theobroma cacao. Heredity, v.9, p.69-77, 1955.

KAERNS, C.A.; INOUYE, D.W. Techniques for pollination biologists. Copyright, Colorado, USA. 1993. 583p.

KAUR, A.; HA, C.O.; JONG, K.; SANDS, V.E.; CHAN, H.T.; ASHTON, P.S. Apomixis may be widespread among trees of the climax rain forest. Nature, v.271, p.440-442, 1978. 
KOPTUR, S. Outcrossing and pollinator limitation of fruit set: breeding systems of neotropical Inga trees (Fabaceae: Mimosoideae). Evolution, v.38, n.5, p.1130-1143, 1984.

KOZLOWSKY, J.; STEARNS, S.C. Hypothesis for the production of excess zygotes: models of bet-hedging and selective abortion. Evolution, v.43, p.1369-1377, 1989.

LANDE, R.; SCHEMSKE, D.W. The evolution of self-fertilization and inbreeding depression in plants. I. Genetic Models. Evolution, v.39, n.1, p.24-40, 1985.

LEITE, R.M.O.; VALLE, R.R.; DIAS, B.R. Relações entre a floração e a frutificação do cacaueiro. Agrotrópica, v.2, n.1, p.11-16, 1990.

LEVIN, D.A.; KERSTER, H.W. Gene flow in seed plants. Evolutionary Biology, v.7, p.139-220, 1974.

LEWIS, D. Structure of the incompatibility gene. III - Types of spontaneous and induced mutation. Heredity, v.5, p.399-414, 1951.

LIMA, R.R.; COSTA, J.P.C. Registro de introduções de plantas de cultura pré-colombiana coletadas na Amazônia brasileira. Belém: CPATU, 1991. 191p. (Documentos, 58).

LLOYD, D.G. Evolution of self-incompatibility and racial differentiation in Leavenworthia (Cruciferae). Contrib. Gray. Herb., v.195, p.3134, 1965.

LLOYD, D.G. Demographic factors and mating patterns in Angiosperms. In: SOLBRIG, O. T. ed. Demographic and Evolution of Plant Populations. Oxford: Blackwell, 1980. p.67.

LOZANO, A. Produção de chocolate feito de cupuaçu quintuplica em um ano. Folha de São Paulo, São Paulo, 17 abr. 1994. p.16.

LOVELESS, M.D.; HAMRICK, J.L. Distribución de la variación en especies de árboles tropicales. Revista de Biologia Tropical, v.35(Supl. 1), p.165-175, 1987. 
LYONS, E.E.; ANTONOVICS, J. Breeding system evolution in Leavenworthia: breeding system variation and reproductive success in natural populations of Leavenworthia crassa (Cruciferae). American Journal of Botany, v.78, n.2, p.270-287, 1991.

MAAS, P.J.M.; WESTRA, L.V.T. Neotropical plant families. Koeltz, Illions, USA. 1993. 289p.

MARDIA, K.V.; KENT, J.T.; BIBBY, J.M. Multivariate analysis. London: Academic Press, 1979. 521p.

MARSHALL, J. Fertility in cocoa. In: 3rd ANNUAL REPORT ON COCOA RESEARCH, Trinidad, 1933. p.34.

MARTIN, F. W. Distily, self-incompatibility, and evolution in Melochia. Evolution, v.21, p.493-499, 1973.

MARTINEZ, W.O.J.; GOODMAN, M.M.; TIMOTHY, D.H. Measuring racial differentiation in maize using multivariate distance measures standartized by variation in F2 populations. Crop Science, v.23, p.772-781, 1983.

MARTINSON, V.A. Embryological studies on hybridization between Theobroma cacao and Theobroma grandiflorum. Canadian Journal of Botany, v.50, p.2117-2124, 1972.

MARTORANO, L.G.; PEREIRA, L.C.; CESAR, E.G. M.; PEREIRA, I. C.B. Estudos climáticos do Estado do Pará, classificação de (Köppen) e deficiência hidrica (Thornthwaite, Mater). Belém, SUDAM/EMBRAPA, 1993. 54p.

MENDOZA, A.V. Estudio de algunas caracteristicas de la biologia floral de Cordia alliodora (Ruiz y Pav.) Cham. Turrialba, Costa Rica, 1965. 75p. Dissertação (Mestrado).

MITTON, J. The dynamic mating systems of conifers. New Forests, v.6, p.197-216, 1992. 
MORAES, V.H. F.; MÜLLER, C.H.; SOUZA, A.G.C.; ANTÔNIO, I.C. Native fruit species of economic potential from the brazilian Amazon. Angew. Bot., v.68, p.47-52, 1994.

MORAIS, O.P. Análise multivariada da divergência genética dos progenitores, indices de seleção e seleção combinada numa população de arroz oriunda de intercruzamentos, usando machoesterelidade. Viçosa, 1992. 251p. Tese (Doutorado) Universidade Federal de Viçosa.

MOREIRA, D. A.; NEVES, M. P. H.; OLIVEIRA, R. P.; SILVA, R. M.; MOTA, M.G.C. Sistema reprodutivo do cupuaçuzeiro (Theobroma grandiflorum) - Alguns aspectos da morfologia floral. In: CONGRESSO BRASILEIRO DE BOTÂNICA - CBB, São Luís, 1993.

MURAWSKI, D.A.; HAMRICK, J.L. The effect of the density of flowering individuals on the mating systems of nine tropical tree species. Heredity, v.67, p.167-174, 1991.

MURAWSKI, D.A.; HAMRICK, J.L. The mating system of Cavanillesia platanifolia under extremes of flowering-tree density: a test of predictions. Biotropica, v.24, p.99-101, $1992 \mathrm{a}$.

MURAWSKI, D.A.; HAMRICK, J.L. Mating system and phenology of Ceiba pentrandra (Bombaceae) in Central Panama. Journal Heredity, v.83, p.401-404, 1992 b.

MURAWSKI, D.A.; DAYANANDAN, B.; BAWA, K.S. Outcrossing rates of two endemic Shorea species from Sri Lanka tropical rain forest. Biotropica, v.26, n.1,p.23-29, 1994.

NAZARÉ, R.F.; BARBOSA, W.C.; VIÉGAS, R.M.F. Processamento das sementes de cupuaçu para a obtenção de cupulate. Belém, CPATU, 1990. 37p (Boletim de Pesquisa, 106).

NETTANCOURT, D. Incompatibility in Angiosperms. Berlin: Springer-Verlag, 1977. 
NEVES, M.P.H.; MOTA, M.G.C.; NASCIMENTO, T.B.; BRANCO, M. V.M.C. Biologia reprodutiva do cupuaçuzeiro (Theobroma grandiflorum) - Estádios da floração e frutificação. In: 1 SEMINÁRIO DE BOLSISTA DE INICIAÇÃO CIENTÍFICA DA FCAP, 1, Belém, 1991.

NEVES, M.P.H.; SILVA, R.M. Sistema reprodutivo do cupuaçuzeiro (Theobroma grandiflorum) - Polinização artificial. In: CONGRESSO BRASILEIRO DE INCIAÇÃO CIENTÍFICA CBICCA, 13., Itaguai, 1992.

NEVES, M.P.H.; MOTA, M.G.C.; MÜLLER, C.H.; MENEZES, M.A.; SILVA, R.M.; BRANCO, M.V.M.C. Sistema reprodutivo do cupuaçuzeiro (Theobroma grandiflorum) 3 - Biologia Floral. In: CONGRESSO BRASILEIRO DE BOTÂNICA, Aracaju, 1992a.

NEVES, M.P.H.; JESUS, M.L.T.; CARREIRA, L.M.; MENEZES, M.A.; SILVA, R.M.; BRANCO, M.V.M.C. Sistema reprodutivo do cupuaçuzeiro (Theobroma grandiflorum) 4 - Estudos palinológicos. In: CONGRESSO BRASILEIRO DE BOTÂNICA, Aracaju, 1992b.

NEVES, M.P.H.; BRANCO, M.V.M.C.C.; SILVA, R.M. Sistema reprodutivo do cupuaçuzeiro (Theobroma grandiflorum) - Antese e viabilidade da flor. In: SEMINÁRIO DE INICIAÇÃO CIENTÍFICA DA UFPa, 3., Belém, 1992c.

NEVES, M.P.H.; SILVA, R.M.; MOREIRA, D.A. Sistema reprodutivo do cupuaçuzeiro (Theobroma grandiflorum) - Cor da flor. In: CONGRESSO BRASILEIRO DE INICIAÇÃO CIENTÍFICA EM CIÊNCIA AGRÁRIAS, 12., Itaguaí, 1992d.

NEVES, M.P.H.; OLIVEIRA, R.P.; MOTA, M.G.C.; SILVA, R.M. Sistema reprodutivo do cupuaçuzeiro (Theobroma grandiflorum) Época de floração, frutificação e mudança foliar. In: CONGRESSO BRASILEIRO DE BOTÂNICA, São Luís, 1993a.

NEVES, M.P.H.; OLIVEIRA, R.P.; MOTA, M.G.C.; SILVA, R.M. Sistema reprodutivo do cupuaçuzeiro (Theobroma grandiflorum) Estádios de floração e frutificação. In: CONGRESSO BRASILEIRO DE BOTÂNICA, São Luís, 1993b. 
NEVES, M.P.H.; OLIVEIRA, R.P.; MOTA, M.G.C.; SILVA, R.M.; PIMENTEL, L.P. Sistema reprodutivo do cupuaçuzeiro (Theobroma grandiflorum) - Besouro mais frequente: praga ou polinizador ?. In: ENCONTRO SOBRE BIOLOGIA VEGETAL TROPICAL, 1., Belém, 1993c.

NEVES, M.P.H.; SILVA, R.M.; OLIVEIRA, R.P.; MOTA, M.G.C. Sistema reprodutivo do cupuaçuzeiro (Theobroma grandiflorum) Tipos de isolamento da flor. In: CONGRESSO BRASILEIRO DE INICIAÇÃO CIENTÍFICA EM CIÊNCIAS AGRÁRIAS, 13., Areia, 1993d.

OLIVEIRA, G.C.X. Padrões de variação ecológica de Oryzae (Poaceae) selvagens da Amazônia. Piracicaba, $1992.303 p$. Dissertação (Mestrado) - Escola Superior de Agricultura "Luiz de Queiroz", Universidade de São Paulo.

OLMSTEAD, R.G. Self-incompatibility in light of population structure and inbreeding. In: MULCAHY et al. (eds.), Biotechnology and ecology of pollen. New York: Springer-Verlag, 1986. p. 239.

O'MALLEY, D.M.; BAWA, K.S. Mating system of a tropical rain forest tree species. American Journal of Botany, v.74, p.1143-1149, 1987.

O'MALLEY, D.M.; BUCKLEY, D.P.; PRANCE, G.T.; BAWA, K.S. Genetics of Brazil nut (Bertholletia excelsa Humb Bonpl: Lecythidaceae). 2. Mating system. Theoretical and Applied Genetics,v.76, p.929-932, 1988.

OPLER, P.A.; FRANKIE, G.W.; BAKER, A.G. Comparative phenological studies of treelet and shrub species in tropical wet and dry forest in the low-lands of Costa Rica. Journal of Ecology, v.68, p.167-88, 1980.

ORNDUFF, R. Reproductive biology in relation to systematics. Taxon, v.18, p.121-133, 1969.

OSTENDORF, F.W. Fertility of cocoa. Chron. Nat., v.104, p.101$105,1948$. 
PADRUTT, J.; PELLETT, H.; ASCHER, P. Postpollination reproductive biology of Rhododendron prinophyllum (Small) Millais. Journal of the American Society for Horticultural Science, v.117, n.4, p.656-662, 1992.

PEREIRA, A.V. Utilização de análise multivariada na caracterização de germoplasma de mandioca (Manihot esculenta Crantz). Piracicaba, 1989. 180p. Tese (Doutorado) - Escola Superior da Agricultura "Luiz de Queiroz", Universidade de São Paulo.

PHILLIPS, M.A.; BROWN, H.D. Mating system and hybridity in Eucalyptus pauciflora. Australian Journal Biology Science, v.30, p.337-344, 1977.

POSNETTE, A.F. Incompatibility in Amazon cocoa. Tropical Agriculture, v.22, p.184-187, 1945.

POUND, F.J. The genetic constitution of the cocoa crop. In: IMPERIAL COLLEGE OF TROPICAL AGRICULTURE. Annual Report on Cocoa Research, Firsth. St. Augustine, Trinidad. 1931. p.10-24.

POUND, F.J. Studies of fruitfulness in cocoa II. Ist ANNUAL REPORT ON COCOA RESEARCH., Trinidad, 1932. p. 26-28.

PRANCE, G.T.; SILVA, M.F. Árvores de Manaus. INPA, 1975. p.249-251.

PURSEGLOVE, J.V. Tropical Crops, Dicotyledons. In: Wiley N. Y. 1968. 322p.

QUELLER, D. C. Sexual selection in a hermaphroditic plant. Nature, v.305, p.706-707, 1983.

RABINOWITZ, D.; RAPP, J.K.; SORK, V.L.; RATHCKE, B.J.; WEAVER, J.C. Phenological properties of wind- and insectpollinated prairie plants. Ecology, v.62, p.49-56, 1981.

RAMALHO, M.P.; SANTOS, J.B.; PINTO, C.B. Genética na Agropecuária. 4 ed. São Paulo: Globo, 1995. 395p. 
RAO, C.R. Advanced statistical methods in biometrics research. New York: Wiley, 1952. 390p.

RAO, C.R.; PRASAD, A.S.R.; SAIKRISHNA, T. Genetic divergence among some brown plant thopper resistant rice varieties. Indian Journal of Genetics Plant Breeding, v.41, p.179-185, 1981.

RATHCKE, B.; LACEY, P.E. Phenological patterns of terrestrial plants. Annual Review of Ecology and Systematics, v.16, p.179-214, 1985.

RESENDE, R. M. S. Aplicação de técnicas de análise multivariada e eletroforese de isoenzimas em estudos de relações fenéticas no gênero Laelia seção Parviflorae. Piracicaba, 1991. 130p. Dissertação (Mestrado) - Escola Superior da Agricultura "Luiz de Queiroz", Universidade de São Paulo.

RIBEIRO, N.C.A.; SACRAMENTO, C.K.; BARRETO, W.G.; FILHO, L. P.S. Características físicas e químicas de frutos de cupuaçuzeiro (Theobroma grandiflorum) do Sudeste da Bahia. Agrotrópica, v.4, n.2, p.33-37, 1993.

RIBOLDI, J. Análise de agrupamento "cluster analysis" e suas aplicações, Piracicaba, Departamento de Estatística/ESALQ, 1986. 33p.

RICK, C.M. Some plant-animal relations in the Galapagos Islands. In: BOWMAN, R. I. ed. The Galapagos Islands. University California. Press, Berkeley.. 1966, p.215-232.

SAS, Institute. SAS procedures guide (Vers. 5). Cary, North Caroline. SAS Institute. 1985.

SCHEMSKE, D.W. Evolution of floral display in the orchid Brasavola nodosa. Evolution, v.34, p.489-493, 1980.

SEAVEY, S.R.; BAWA, K.S. Late-acting self-incompatibility in angiosperms. Botany Review, v.52, p.195-219, 1986.

SEDGLEY, M.; ATTANAYAKE, D.P.G. The breeding system of rubber (Hevea brasiliensis): an avaluation of controlled hand pollination methods. Euphytica, v.39, p.83-91, 1988. 
SHORE, J.S.; BARRETT, S.C.H. Morphological differentiation and crossability among populations of the Turnera ulmifolia L. complex (Turneraceae). Systematic Botany, v.10, p.308-321, 1986.

SILVA, M.F. Insetos que visitam o "Cupuaçu", Theobroma grandiflorum (Willd. ex Spreng. Schum. (Sterculiaceae) e indice de ataque nas folhas. Acta Amazônica, v.6, n.1, 49-54. 1976

SILVA, R.M.; NEVES, M.P.H.; OLIVEIRA, R.P.; MOTA, M.G.C. Sistema reprodutivo do cupuaçuzeiro (Theobroma grandifforum) Botão floral. In: I - SEMINÁRIO DE BOLSISTA DE INICIAÇẤO CIENTÍFICA DO MUSEU GOELDI e III da FCAP, Belém, 1993a.

SILVA, R.M.; NEVES, M.P.H.; OLIVEIRA, R.P.; MOTA, M.G.C. Sistema reprodutivo do cupuaçuzeiro (Theobroma grandiflorum) Determinação da receptibilidade do estigma e estilete. In: CONGRESSO BRASILEIRO DE BOTÂNICA, São Luis, 1993b.

SINGH, R.K.; CHAUDHARY, B.D. Biometrical methods in quantitative genetic analysis. Ludhiana: Kalyani Publishers, I. 1979. 304p.

SINGH; Y.P.; KUMAR, A.; CHAUHAN, B.P.S. Genetic divergence in pearl millet. Ind. J. Genet. Plant Breed., v.44, p.186-190, 1981.

SNEATH, P.H.A.; SOKAL, R.R. Numerical taxonomy. San Francisco: W. H. Freeman and Company, 1973.573p.

SOARES, L. Melhoramento de batata-baroa (Arracacia xanthorrhiza Bancroft): divergência genética entre clones com base em procedimentos multivariados e estimativas de parâmetros genéticos. Viçosa, 75p. 1991 Dissertação (Mestrado) Universidade Federal de Viçosa.

SOBREVILA, C.; ARROYO, M.T.K. Breeding systems in a montane tropical cloud forest in Venezuela. Plant Systematic and Evolution, v.140, p.19-37, 1982.

SOKAL, R.R.; MICHENER, C.D. A statistical method for evaluating systematic relationships. University of Kansas Science Bulletin, v.38, v.1406-1438, 1958. 
SOUZA, J.C. Divergência genética entre acessos de Acerola (Malpighia sp.) com base em dados isozimáticos e agronômicos. Viçosa, 67 p. Dissertação (Mestrado) Universidade Federal de Viçosa.

SORIA, J.; SILVA, P.; CHAPMAN, R.K. Influence of floral pigmentation on field pollination rates in some cultivated varieties of Theobroma cacao L.: some effects on yield. Theobroma, v.13, p.141-149, 1982.

STEPHENSON, A.G. An evolutionary examination of the floral display of Catalpa speciosa (Bignoniaceae). Evolution, v.33, p.12001209, 1979.

STEPHENSON, A.G. Flower an fruit abortion: proximate causes and ultimate functions. Annual Review of Ecology and Systematics, v.12, p.253-279, 1981.

STEPHENSON, A.G.; BERTIN, R.I. Male competition, female choice, and sexual selection in plants. In REAL, L. ed. Pollination biology. New York: Academic Press, 1983. p. 109-149.

STEPHENSON, A. G. The cost of over-initiating fruit. American Midland Naturalist, v.112, p.379-386, 1984.

SUTHERLAND, S. Floral sex ratios, fruit-set, and resource allocation in plants. Ecology, v.67, p.991-1001, 1986.

SUTHERLAND, S. Why hermaphroditic plants produce many more flowers than fruits: experimental tests with Agave mckelveyana. Evolution, v.41, p.750-759, 1987.

SUTHERLAND, S.; DELPH, L.F. On the importance of male fitness in plants: patterns of fruit-set. Ecology, v. 65, p.1093-1104, 1984.

TARODA, N.; GIBBS, P.E. Floral biology and breeding system of Sterculia chicha St. Hil. (Sterculiaceae). New Phytology, v.90, p.735-743, 1982. 
THOMSON, J.D.; STRATTON, D.A. Floral morphology and crosspollination in Erythronium grandiflorum (Liliaceae). American Journal of Botany, v.72, n.3, p.433-437, 1985.

VAUGTON, G. Variation between years in pollen and nutrient limitation of fruit set in Banksia spinulosa. Journal of Ecology, v.78, p.389$400,1991$.

VENTURIERI, G.A. Cupuaçu: A espécie, sua cultura, usos, e processamento. Belém, 1993. 108p.

VENTURIERI, G.A. Floral Biology of Cupuassu (Theobroma grandiflorum (Willdenow ex Sprengel) Schumann). Reading, 1994. 206p. Thesis (Doctor of Philosophy) - University of Reading.

VENTURIERI, G. A polinização do cupuaçu não é mais segredo 0 Liberal, Belém, 26 mar. 1996. p.8.

VIANA, J.M.S. Divergência genética, estabilidade e adaptabilidade de clones de cana-de-açucar (Sacharum spp.). Viçosa, 1990. 108p. Dissertação (Mestrado) - Universidade Federal de Viçosa.

VOELCKER, O.J. Self-incompatibility in cocoa. 6th ANNUAL REPORT ON COCOA RESEARCH, Trinidad, 1937. p. 2-5.

VOELCKER, O.J. Self-incompatibility in cocoa II. 7th ANNUAL REPORT ON COCOA RESEARCH, Trinidad, 1938, p. 2-5.

WARREN, J.; KALAl; MISIR, S. An unnatural breeding system polymorphysm in cocoa (Theobroma cacao, Sterculiaceae) in Trinidad. American Journal of Botany, v.82, n.9, p.1126-1130, $1995 a$.

WARREN, J.M.; MISIR, S.; KALAI. J. Isozyme markers for selfcompatibility and yield in Theobroma cacao (cocoa). Heredity, v.74, p.354-356, 1995b.

WETTSTEIN, R. Tratado de botânica e sistemática. Buenos Aires: Labor. 1944. 1039p. 
WIENS, D. Ovule survivorship, brood size, life history, breeding systems, and reproductive success in plants. Oecologia, v.64, p.47-53, 1984.

WILLSON, M.F.; RATHCKE, B.J. Adaptative design of the floral display in Asclepias syriaca L. American Midland Naturalist, v.92, p.47-57, 1974.

WILLSON, M.F.; SCHEMSKE, D.W. Pollinator-limitation, fruit production, and floral display in paw paw. Bulletin Terrey Botany Club, v.107, p.401-408, 1980.

YAMADA, M.M.; BARTLEY, B.G. D.; MELO, G.R.P. Herança do fator compatibilidade em Theobroma cacao L. I. Relações fenotípicas na familia PA (Parimari). Revista Theobroma, v.12, n.3, p.163167, 1982.

ZAPATA, R.T.; ARROYO, M.T.K. Plant reproductive ecology of a secondary tropical deciduous forest in Venezuela. Biotropica, v.10, n.3, p.221-230,1978. 